\title{
\#USGS
}

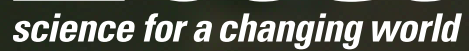

Prepared in cooperation with the United States Fish and Wildlife Service

\section{Physical Characteristics of the Lower San Joaquin River, California, in Relation to White Sturgeon Spawning Habitat, 2011-14}

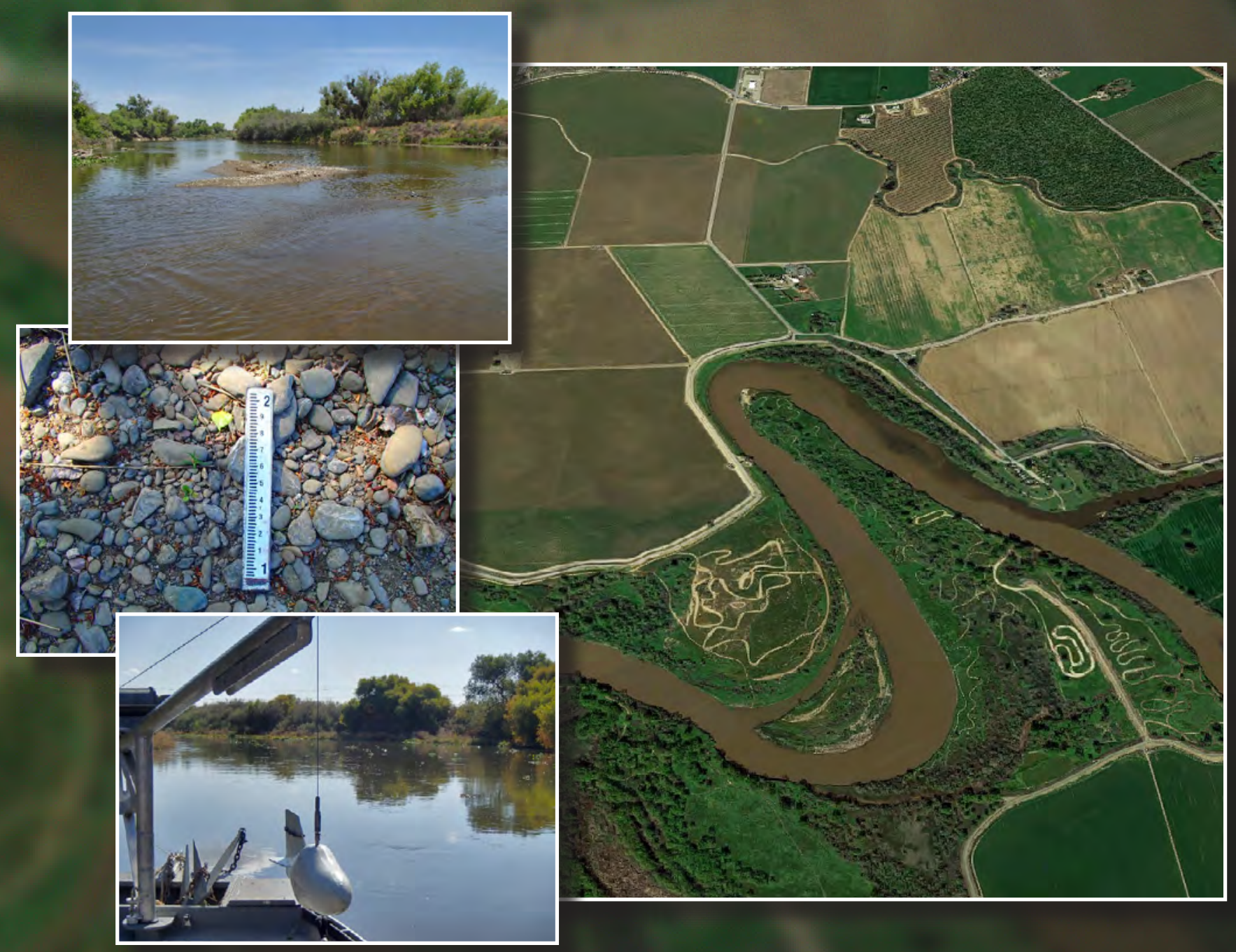

Scientific Investigations Report 2017-5069 


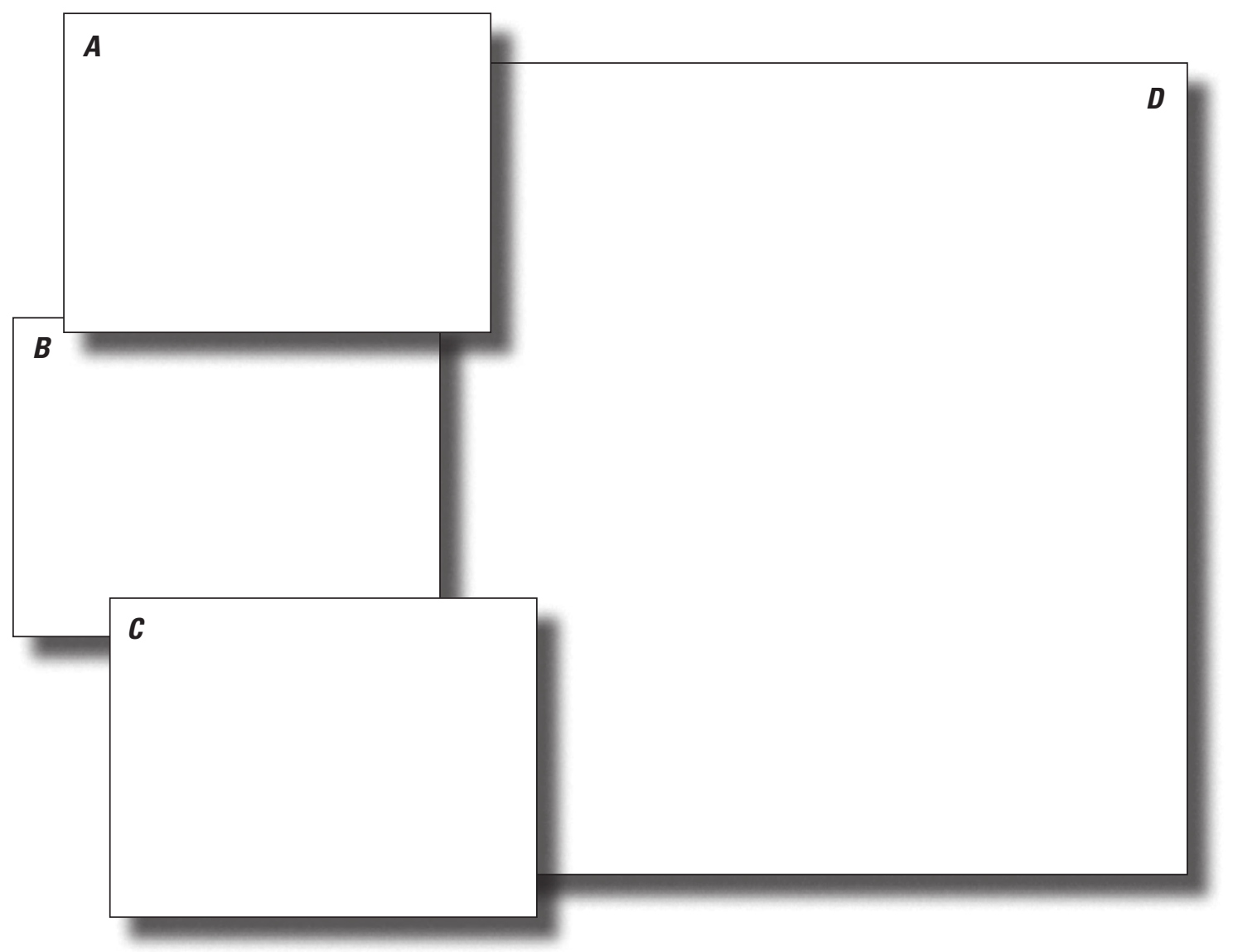

Cover. Front cover photographs taken by Mathieu Marineau: $A$, Gravel bar in the San Joaquin River at the mouth of Orestimba Creek. $B$, Close up view of cobble and gravel found in the bed of Del Puerto Creek, near the confluence with the San Joaquin River. $C$, Bed material sampler during field work in the San Joaquin River. D, Oblique aerial image showing the San Joaquin River at Sturgeon Bend and confluence of the Stanislaus River (NAIP, 2012). 


\section{Physical Characteristics of the Lower San Joaquin River, California, in Relation to White Sturgeon Spawning Habitat, 2011-14}

By Mathieu D. Marineau, Scott A. Wright, Daniel R. Whealdon-Haught, and

Paul J. Kinzel

Prepared in cooperation with the United States Fish and Wildlife Service

Scientific Investigations Report 2017-5069 


\title{
U.S. Department of the Interior \\ RYAN K. ZINKE, Secretary
}

\section{U.S. Geological Survey William H. Werkheiser, Acting Director}

\author{
U.S. Geological Survey, Reston, Virginia: 2017
}

For more information on the USGS - the Federal source for science about the Earth, its natural and living resources, natural hazards, and the environment—visit http://www.usgs.gov or call 1-888-ASK-USGS.

For an overview of USGS information products, including maps, imagery, and publications, visit http://www.usgs.gov/pubprod/.

Any use of trade, firm, or product names is for descriptive purposes only and does not imply endorsement by the U.S. Government.

Although this information product, for the most part, is in the public domain, it also may contain copyrighted materials as noted in the text. Permission to reproduce copyrighted items must be secured from the copyright owner.

Suggested citation:

Marineau, M.D., Wright, S.A., Whealdon-Haught, D.R., Kinzel, P.J., 2017, Physical characteristics of the lower San Joaquin River, California, in relation to white sturgeon spawning habitat, 2011-14: U.S. Geological Survey Scientific Investigation Report 2017-5069, 47 p., https://doi.org/10.3133/sir20175069.

ISSN 2328-0328 (online) 


\section{Contents}

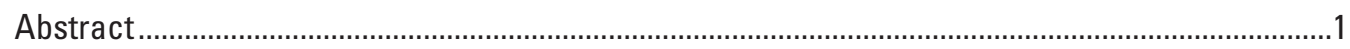

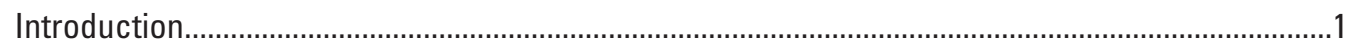

Description of the San Joaquin River Basin ....................................................................

Lower San Joaquin River and its Tributaries ................................................................... 2

Study Area, River Reaches, and Subreaches .................................................................

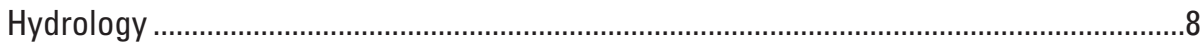

White Sturgeon Ecology ..................................................................................................11

White Sturgeon Monitoring in the San Joaquin River by the U.S. Fish and

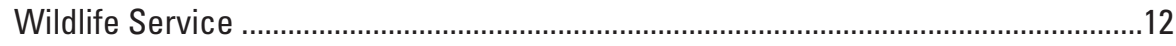

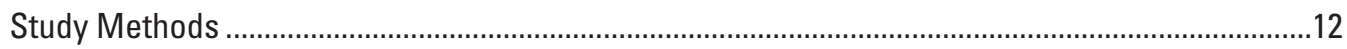

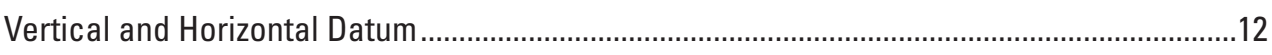

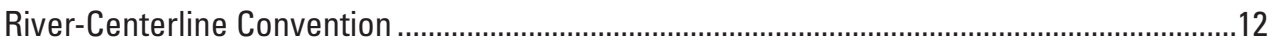

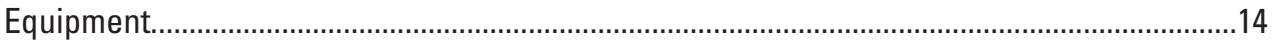

Multibeam Echosounder System ..................................................................................14

Acoustic Doppler Current Profiler ............................................................................14

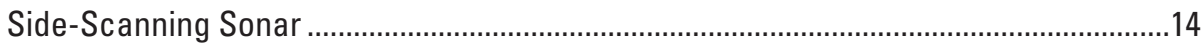

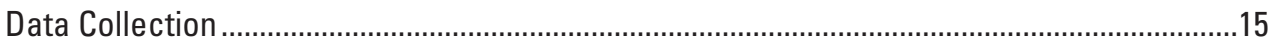

Water Depth and Velocity Measurements using Acoustic Doppler Current

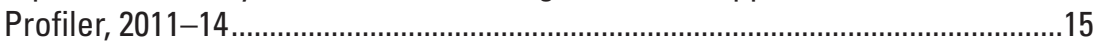

Bathymetry Mapping using Multibeam Sonar, 2011 ....................................................17

Bed-Material Mapping using Acoustic Backscatter in 2012 and Side-Scan

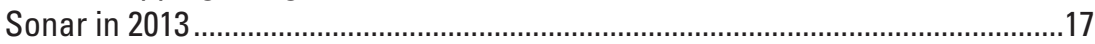

Tributary Longitudinal Elevation and Slope Profiles .....................................................17

Bed-Material Sampling, 2012-14 ...........................................................................19

Bed-Material Sample Preparation and Particle-Size Analysis........................................21

Summary of Channel Characteristics, Stream Slope, and Bed Aggradation in the

Lower San Joaquin River ..................................................................................................22

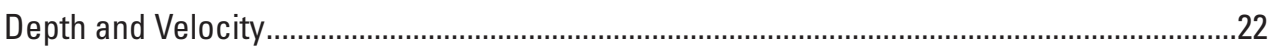

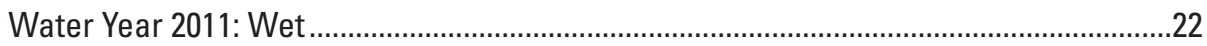

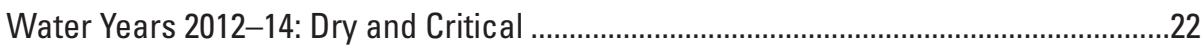

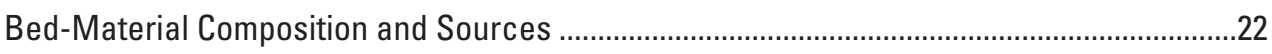

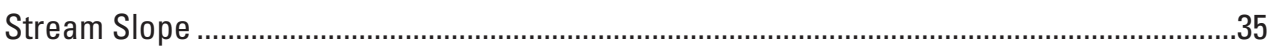

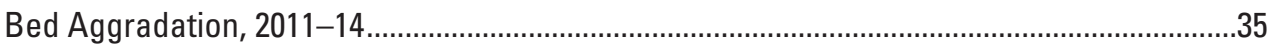

Discussion and Conclusions: Bed Material and Streamflow in the Lower San Joaquin River .....38

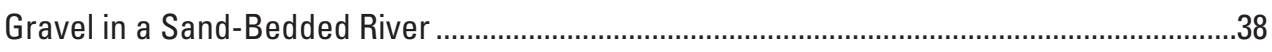

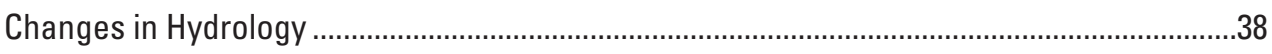

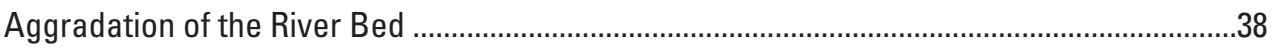

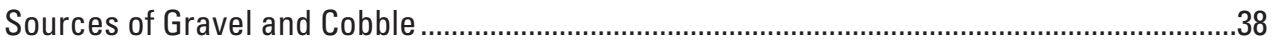

Summary

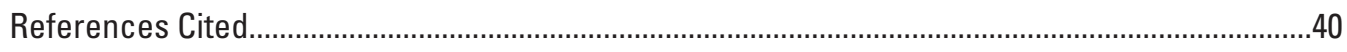

Appendix 1: River Kilometer Station Locations ........................................................................ 


\section{Figures}

1. Map showing the San Joaquin Basin, Tulare Basin, and lower San Joaquin River study area, California

2. Photograph showing large, broken concrete slabs, which are used as bank protection in many areas of the lower San Joaquin River, California .4

3. Photograph showing stones (mostly cobble size), which are used as bank protection in many areas of the lower San Joaquin River, California

4. Photograph showing typical consolidated bank on the lower San Joaquin River, California

5. Map showing lower San Joaquin River reaches, subreaches of interest, locations of selected U.S. Geological Survey and California Department of Water Resources streamgages, river kilometer stations, and 2011-12 U.S. Fish and Wildlife Service sturgeon-egg sampling sites

6. Hydrographs showing annual peak streamflow, measured as instantaneous discharge at selected streamgages, and the time of dam completion, where applicable, in the San Joaquin Basin, California, 1920-2010.

7. Hydrographs showing daily average streamflow, measured as discharge at the U.S. Geological Survey streamgage at Vernalis (station 11303500), for the lower San Joaquin River, California, categorized by water-year type for water years 1924, 1930-67 and 1968-2014

8. Hydrographs showing the daily mean streamflow, measured as discharge, during the study (water years 2011-14) relative to the historical range of discharge measured on the San Joaquin River, California, at the U.S. Geological Survey streamgage at Vernalis (station 11303500)

9. Hydrograph and maps showing the dates and locations of the U.S. Fish and Wildlife Service sampling and U.S. Geological Survey data collection, 2011-12 13

10. Maps showing locations where water depth and velocity data were collected, by year, in the lower San Joaquin River, California, 2011-14

11. Images showing examples of side-scan sonar from a sand-bedded section in the Grayson Bridge subreach of the lower San Joaquin River, California, April 23, 2013.....18

12. Image showing plan view of side-scan sonar of a gravel-bedded section in the Grayson Bridge subreach of the lower San Joaquin River, California, April 23, 2013.....19

13. Maps showing sites where bed-material samples were collected in the lower San Joaquin River, Del Puerto Creek, and Orestimba Creek, California ....

14. Maps showing water depth in the lower San Joaquin River, California ..........................23

15. Maps showing depth-averaged velocity in the lower San Joaquin River, California .....24

16. Images showing water depth and bed-material size class in the Sturgeon Bend subreach of the lower San Joaquin River, California

17. Images showing water depth and bed-material size class in the Old Fisherman's Club subreach of the lower San Joaquin River, California

18. Images showing water depth and bed-material size class in the Grayson Bridge subreach of the lower San Joaquin River, California

19. Images showing streamflow depth-averaged velocity and bed-material size class in the Sturgeon Bend subreach of the lower San Joaquin River, California 


\section{Figures-Continued}

20. Images showing streamflow depth-averaged velocity and bed-material size class in the Old Fisherman's Club subreach of the lower San Joaquin River, California..........29

21. Images showing streamflow depth-averaged velocity and bed-material size class in the Grayson Bridge subreach of the lower San Joaquin River, California ...................30

22. Photograph showing cobble in the dry bed of Orestimba Creek at Eastin Road, approximately 5 kilometers northwest of Newman, California, April 24, 2014 .................31

23. Photograph showing the edge of a large gravel bar in the lower San Joaquin River at river kilometer 146.3, the mouth of Del Puerto Creek, California, November 8, 2013...

24. Photograph showing the mouth of Del Puerto Creek, California, November 8, 2013, where the channel cut through a large gravel deposit.

25. Photograph showing the dry channel bed of Del Puerto Creek, 22 kilometers upstream from its confluence with the lower San Joaquin River, California, November 1, 2013

26. Photograph showing Del Puerto Creek at Rogers Road, November 1, 2013 ...................33

27. Photograph showing an exposed gravel bar in the lower San Joaquin River, California, near river kilometer 171.8, the mouth of Orestimba Creek, May 13, 2014 ......33

28. Graphs summarizing particle-size distribution of bed material samples collected from channels during 2011-13.

29. Graphs showing longitudinal profiles of water-surface elevation, water-surface slope, and principal dams in rivers and creeks of the San Joaquin Basin, California....36

30. Graph showing bed-elevation changes along selected longitudinal section in the Sturgeon Bend subreach, lower San Joaquin River, California, 2011-14.

31. Graph showing bed-elevation changes along selected longitudinal section in the Grayson Bridge subreach, San Joaquin River, California, 2011-14

\section{Tables}

1. River reaches and subreaches of the lower San Joaquin River and the respective downstream and upstream river kilometer stations

2. Selected landmarks and geographical features along the lower San Joaquin River, by river kilometers and geographical coordinates

3. Summary of hydroacoustic data collection sites, including daily mean streamflow, measured as discharge, in the reach during data collection and the exceedance probability of that discharge.

4. Description and size range of sediment particles in particle-size categories used in this report.

1-1. River kilometer stations, and their associated geographic coordinates, based on the 2012 National Aerial Imagery Program aerial imagery of the lower San Joaquin River. 


\section{Conversion Factors}

International System of Units to U.S. customary units

\begin{tabular}{lcl}
\hline \multicolumn{1}{c}{ Multiply } & By & \multicolumn{1}{c}{ To obtain } \\
\hline centimeter $(\mathrm{cm})$ & Length & inch (in.) \\
millimeter $(\mathrm{mm})$ & 0.3937 & inch (in.) \\
meter $(\mathrm{m})$ & 0.03937 & foot $(\mathrm{ft})$ \\
kilometer $(\mathrm{km})$ & 3.281 & mile $(\mathrm{mi})$ \\
meter $(\mathrm{m})$ & 0.6214 & yard $(\mathrm{yd})$ \\
\hline & 1.094 & \\
\hline square kilometer $\left(\mathrm{km}^{2}\right)$ & Area & acre \\
square kilometer $\left(\mathrm{km}^{2}\right)$ & 247.1 & square mile $\left(\mathrm{mi}^{2}\right)$ \\
\hline & 0.3861 & \\
\hline cubic meter $\left(\mathrm{m}^{3}\right)$ & Volume & cubic foot $\left(\mathrm{ft}^{3}\right)$ \\
cubic meter $\left(\mathrm{m}^{3}\right)$ & 35.31 & cubic yard $\left(\mathrm{yd} \mathrm{d}^{3}\right)$ \\
cubic meter $\left(\mathrm{m}^{3}\right)$ & 1.308 & acre-foot $(\mathrm{acre}-\mathrm{ft})$ \\
cubic kilometer $\left(\mathrm{km}^{3}\right)$ & 0.0008107 & acre-foot $(\mathrm{acre}-\mathrm{ft})$ \\
cubic kilometer $\left(\mathrm{km}^{3}\right)$ & 810,714 & cubic mile $\left(\mathrm{mi}^{3}\right)$ \\
\hline & 0.2399 & \\
\hline cubic meter per second $\left(\mathrm{m}^{3} / \mathrm{s}\right)$ & Flow rate & acre-foot per day $(\mathrm{acre}-\mathrm{ft} / \mathrm{d})$ \\
meter per second $(\mathrm{m} / \mathrm{s})$ & 70.07 & foot per second $(\mathrm{ft} / \mathrm{s})$ \\
cubic meter per second $\left(\mathrm{m}^{3} / \mathrm{s}\right)$ & 3.281 & cubic foot per second $(\mathrm{ft} 3 / \mathrm{s})$ \\
millimeter per year $(\mathrm{mm} / \mathrm{yr})$ & 35.31 & inch per year $(\mathrm{in} / \mathrm{yr})$ \\
\hline
\end{tabular}

Temperature in degrees Celsius $\left({ }^{\circ} \mathrm{C}\right)$ may be converted to degrees Fahrenheit $\left({ }^{\circ} \mathrm{F}\right)$ as

$$
{ }^{\circ} \mathrm{F}=\left(1.8 \times{ }^{\circ} \mathrm{C}\right)+32 .
$$

\section{Datum}

Vertical coordinate information is referenced to the North American Vertical Datum of 1988 (NAVD 88).

Horizontal coordinate information is referenced to the North American Datum of 1983 (NAD 83).

Elevation, as used in this report, refers to distance above the vertical datum. 


\section{Abbreviations}

$\begin{array}{ll}\text { ADCP } & \text { acoustic Doppler current profiler } \\ \text { GNSS } & \text { Global Navigation Satellite System } \\ \text { GPS } & \text { global positioning system } \\ \text { kHz } & \text { kilohertz } \\ \text { MAF } & \text { million acre feet } \\ \text { MHz } & \text { megahertz } \\ \text { MRU } & \text { motion reference unit } \\ \text { NAIP } & \text { National Aerial Imagery Program } \\ \text { Rkm } & \text { river kilometer } \\ \text { RO } & \text { annual runoff } \\ \text { RTK-GPS } & \text { real-time kinematic global positioning system } \\ \text { RTN-GPS } & \text { real-time network global positioning system } \\ \text { USFWS } & \text { U.S. Fish and Wildlife Service } \\ \text { USGS } & \text { U.S. Geological Survey } \\ \text { WY } & \text { water year }\end{array}$





\title{
Physical Characteristics of the Lower San Joaquin River, California, in Relation to White Sturgeon Spawning Habitat, 2011-14
}

\author{
By Mathieu D. Marineau, Scott A. Wright, Daniel R. Whealdon-Haught, and Paul J. Kinzel
}

\section{Abstract}

The U.S. Fish and Wildlife Service confirmed that white sturgeon (Acipenser transmontanus) recently spawned in the lower San Joaquin River, California. Decreases in the San Francisco Bay estuary white sturgeon population have led to an increased effort to understand their migration behavior and habitat preferences. The preferred spawning habitat of other white sturgeon (for example, those in the Columbia and Klamath Rivers) is thought to be areas that have high water velocity, deep pools, and coarse bed material. Coarse bed material (pebbles and cobbles), in particular, is important for the survival of white sturgeon eggs and larvae. Knowledge of the physical characteristics of the lower San Joaquin River can be used to preserve sturgeon spawning habitat and lead to management decisions that could help increase the San Francisco Bay estuary white sturgeon population.

Between 2011 and 2014, the U.S. Geological Survey, in cooperation with the U.S. Fish and Wildlife Service, assessed selected reaches and tributaries of the lower river in relation to sturgeon spawning habitat by (1) describing selected spawning reaches in terms of habitat-related physical characteristics (such as water depth and velocity, channel slope, and bed material) of the lower San Joaquin River between its confluences with the Stanislaus and Merced Rivers, (2) describing variations in these physical characteristics during wet and dry years, and (3) identifying potential reasons for these variations.

The lower San Joaquin River was divided into five study reaches. Although data were collected from all study reaches, three subreaches where the USFWS collected viable eggs at multiple sites in 2011-12 from Orestimba Creek to Sturgeon Bend were of special interest. Water depth and velocity were measured using two different approaches - channel cross sections and longitudinal profiles - and data were collected using an acoustic Doppler current profiler.

During the first year of data collection (water year 2011), runoff was greatest, and gaged streamflow, measured as discharge, peaked at 875 cubic meters per second in the lower San Joaquin River. Also during that year, water velocity was generally between 0.6 and 0.9 meters per second, and depth was typically between 2.5 and 4.5 meters, but water depth exceeded 6 meters in several pools. Water year 2011 was classified as a "wet" year. Later water years were classified as either "dry" (water year 2012) or "critical" (water years 2013 and 2014). During the drier years, water was shallower, and velocities were slower. The streambed aggraded in several areas during the study. At Sturgeon Bend, for example, which had the deepest pool measured in 2011 (maximum depth was 14 meters), about 8 meters of sediment was deposited by 2014 .

The bed of the lower San Joaquin River was predominately sand, except in areas downstream from the mouth of Del Puerto Creek. A large amount of sand, gravel, and cobble was deposited at the mouth of Del Puerto Creek, and in the 9.5 kilometers downstream from the mouth of Del Puerto Creek, we encountered several gravel bars and patches of gravel-size (8-64 millimeters) bed material. Del Puerto and Orestimba Creeks drain from the Coast Ranges on the west side of the river. Only small quantities of gravel-size bed material were observed in the reach downstream from Orestimba Creek, indicating Orestimba Creek does not deliver much coarse sediment to the lower San Joaquin River. Del Puerto Creek appeared to be the primary source of gravels suitable for white sturgeon spawning in the lower San Joaquin River, and thus, it is important for the long-term spawning success of sturgeon in the San Joaquin River.

\section{Introduction}

White sturgeon (Acipenser transmontanus) have long been known to inhabit the San Francisco Bay estuary and migrate up the Sacramento River to spawn (Kohlhorst, 1976; Schaffter, 1997). They have been known to migrate up the lower San Joaquin River (Moore and others, 1990), but it was only speculated that they actually spawn there (for example, Kohlhorst, 1976; Schaffter, 1997). Viable white sturgeon eggs were collected by the U.S. Fish and Wildlife Service (USFWS) at one sampling site in 2011 and at four sampling sites in 2012, providing evidence of spawning activity in the lower San Joaquin River (Gruber and others, 2012; Jackson and Van Eenennaam, 2013). 
White sturgeon face many stressors, including fishing, poaching, degraded habitat, and recruitment failures (Birstein, 1993; Gross and others, 2002; Jackson and others, 2016). Decreases in the population of white sturgeon in the Sacramento-San Joaquin drainage (Central Valley watershed) have been a management concern for the last century (Klimley and others, 2015).

Given the evidence of spawning adults, managers are interested in learning more about the physical characteristics of the lower San Joaquin River, particularly the hydraulic conditions and bed-material sediment types. Research in the Columbia and Kootenai Rivers of the Pacific Northwest indicated that high streamflow velocity and coarse bed material increased the survival of white sturgeon eggs and larvae (Parsley and others, 1993; Parsley and Beckman, 1994; Billard and Lecointre, 2000). Identifying the physical characteristics of the river where white sturgeon spawn can help protect their habitat and increase their survival to the larval drift stage of the life cycle. In response to the need to characterize the physical habitat and bed-material sediment characteristics of the lower San Joaquin River, the U.S. Geological Survey (USGS) initiated this study in cooperation with the U.S. Fish and Wildlife Service (USFWS). This study investigated physical characteristics of selected reaches of the lower San Joaquin River in relation to sturgeon spawning habitat.

The purposes of this report are (1) to describe select spawning sites in terms of habitat-related physical characteristics (such as stream depth, velocity, and bed material) in the lower San Joaquin River between the confluences of the Stanislaus and Merced Rivers, (2) to document variations in these physical characteristics during wet and dry years, and (3) to identify potential factors linked to these variations.

The physical characteristic data also can be used to develop habitat-suitability curves for white sturgeon in the lower San Joaquin River and to help develop hydraulic and sediment transport models for reaches of interest. In this report, we describe hydraulic conditions, bed-material characteristics, and the hydrologic history of the lower San Joaquin River in the context of spawning preferences of white sturgeon. Neither the physical transport models nor habitat-suitability curves were developed as part of this report, however.

\section{Description of the San Joaquin River Basin}

The San Joaquin Valley is in the southern part of the Central Valley watershed (fig. 1). The San Joaquin Valley can be divided into two large basins: the San Joaquin Basin to the north and the Tulare Basin to the south. Historically, the Tulare Basin had a large waterbody known as Tulare Lake, into which streams flowed that drained the Tulare Basin. The water level in the lake fluctuated depending on inflows from precipitation and snowmelt runoff, and water would often overflow to Fresno Slough, toward the San Joaquin River (Tinkham, 1921). Agricultural diversions of Tulare Lake's tributary rivers and streams, however, caused the lake to dry out by the end of the 19th century (Wright, 1899). In addition, the combination of dam construction, surface-water diversion, and groundwater extraction resulted in the loss of hydrologic connectivity between the Tulare Basin and the San Joaquin Basin, except when the King River occasionally floods, which can still contribute streamflow to the San Joaquin Basin.

\section{Lower San Joaquin River and its Tributaries}

The lower San Joaquin River begins around river kilometer (Rkm) 234 and flows to the Sacramento-San Joaquin Delta to its confluence with the Sacramento River at Rkm 0. Upstream from Rkm 234, the San Joaquin River historically flowed through a low-lying area and had multiple interconnected channels that frequently overflowed to the surrounding land, forming freshwater wetlands. Upstream from this section, flow in the San Joaquin River is regulated by Friant Dam, and much of the water released is diverted at the Mendota Dam and Sack Dam for agricultural use (California Regional Water Quality Control Board, 1989). During high flows, water is diverted at the San Joaquin River Control Structure (California Department of Water Resources, 2010), but the diverted water eventually flows back to the San Joaquin River through the Mariposa Bypass (Rkm 234).

The lower San Joaquin River is a low-gradient, singlechannel, generally sand-bedded, meandering river. Although most of the banks are natural, there are large sections that have revetted banks (that is, sloping banks covered with large rocks to reduce bank erosion and river migration; figs. 2, 3). Sections where both banks are revetted tend to be narrower than sections with natural banks. In areas of active channel migration, mature trees often fall in the river channel and can remain for years (fig. 4).

Streamflow in the lower San Joaquin River is primarily from the Stanislaus, Tuolumne, and Merced Rivers; from the "middle" San Joaquin River through the Mariposa Bypass; and, to a lesser degree, from Del Puerto and Orestimba Creeks. The four rivers flow west from the Sierra Nevada, and all are regulated by dams. By contrast, the two creeks flow east from the Coast Ranges, do not have any dams, and are ephemeral. Streamflow in the lower San Joaquin River is also affected by numerous agricultural diversions (California Regional Water Quality Control Board, 1989).

There are a few other streams that flow from the Coast Ranges (for example, Hospital and Ingram Creeks), which drain smaller watersheds and appear to have more poorly defined channels in the flatter areas of the valley floor. Most of these creeks have been diverted into agricultural water-supply canals. Early land maps and historical accounts do not show or mention Hospital and Ingram Creeks (formerly Arroyo de Ospital and Arroyo de la Suerte, respectively) as tributaries of the San Joaquin River (for example, Grimes, 1858; Hall, 1886; Reed and others, 1891). 


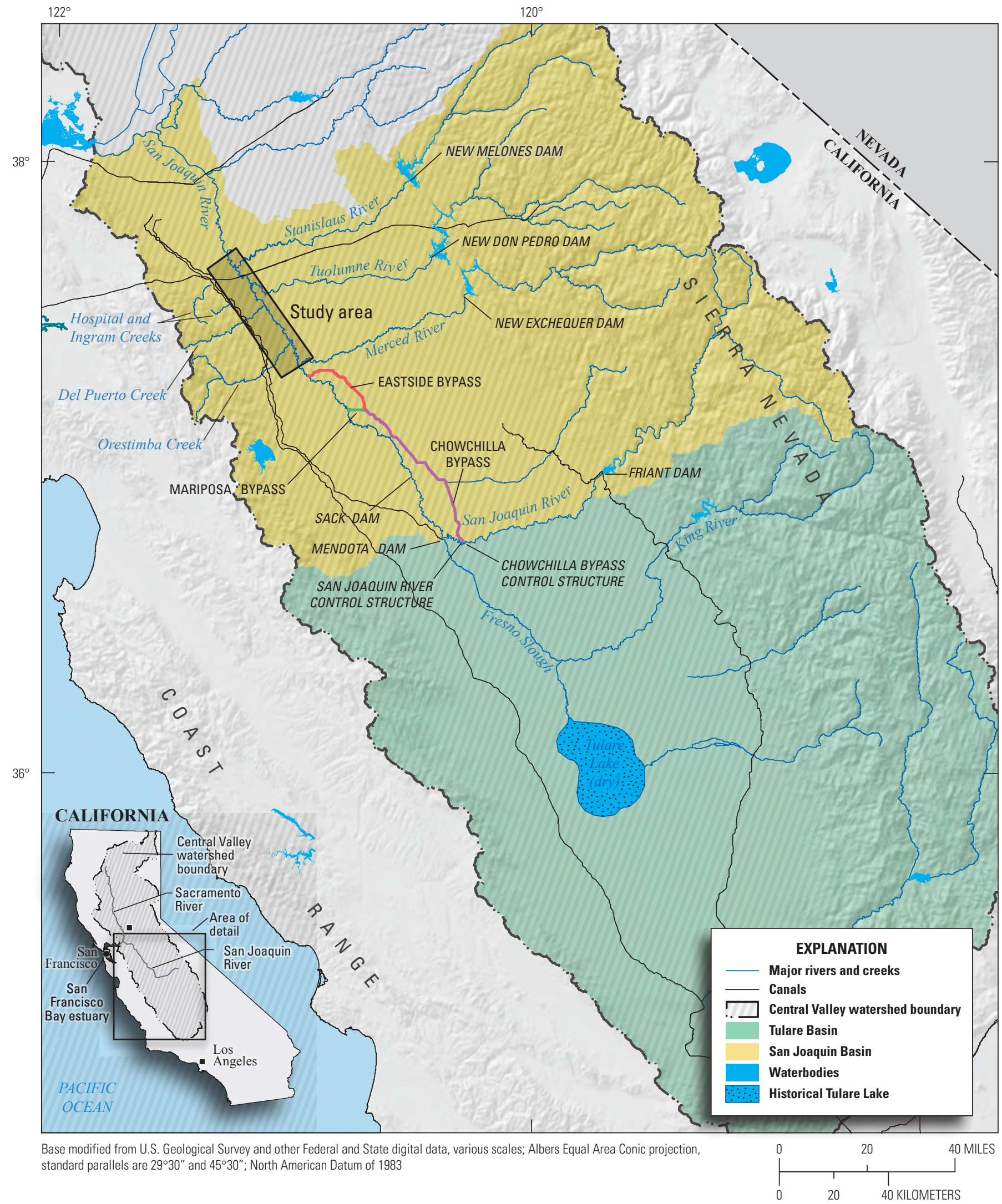

Figure 1. San Joaquin Basin, Tulare Basin, and lower San Joaquin River study area, California. 


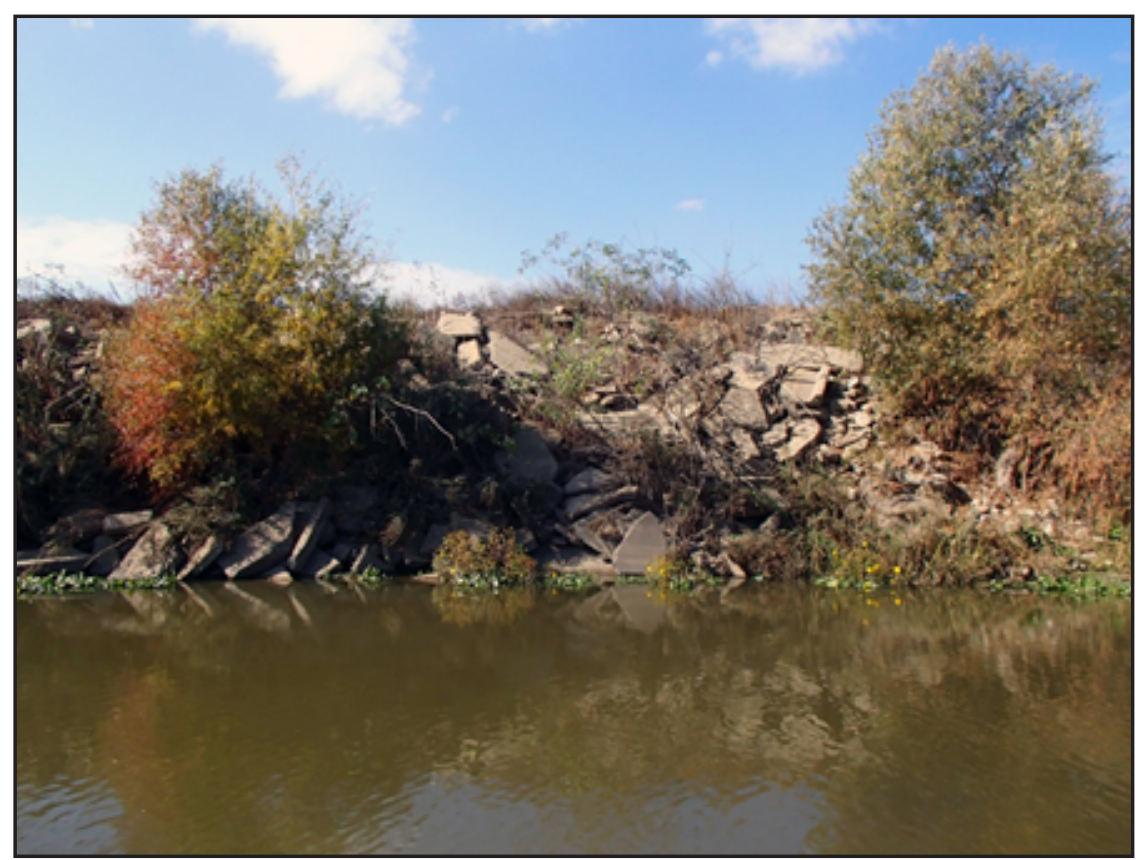

Figure 2. Large, broken concrete slabs, which are used as bank protection in many areas of the lower San Joaquin River, California.

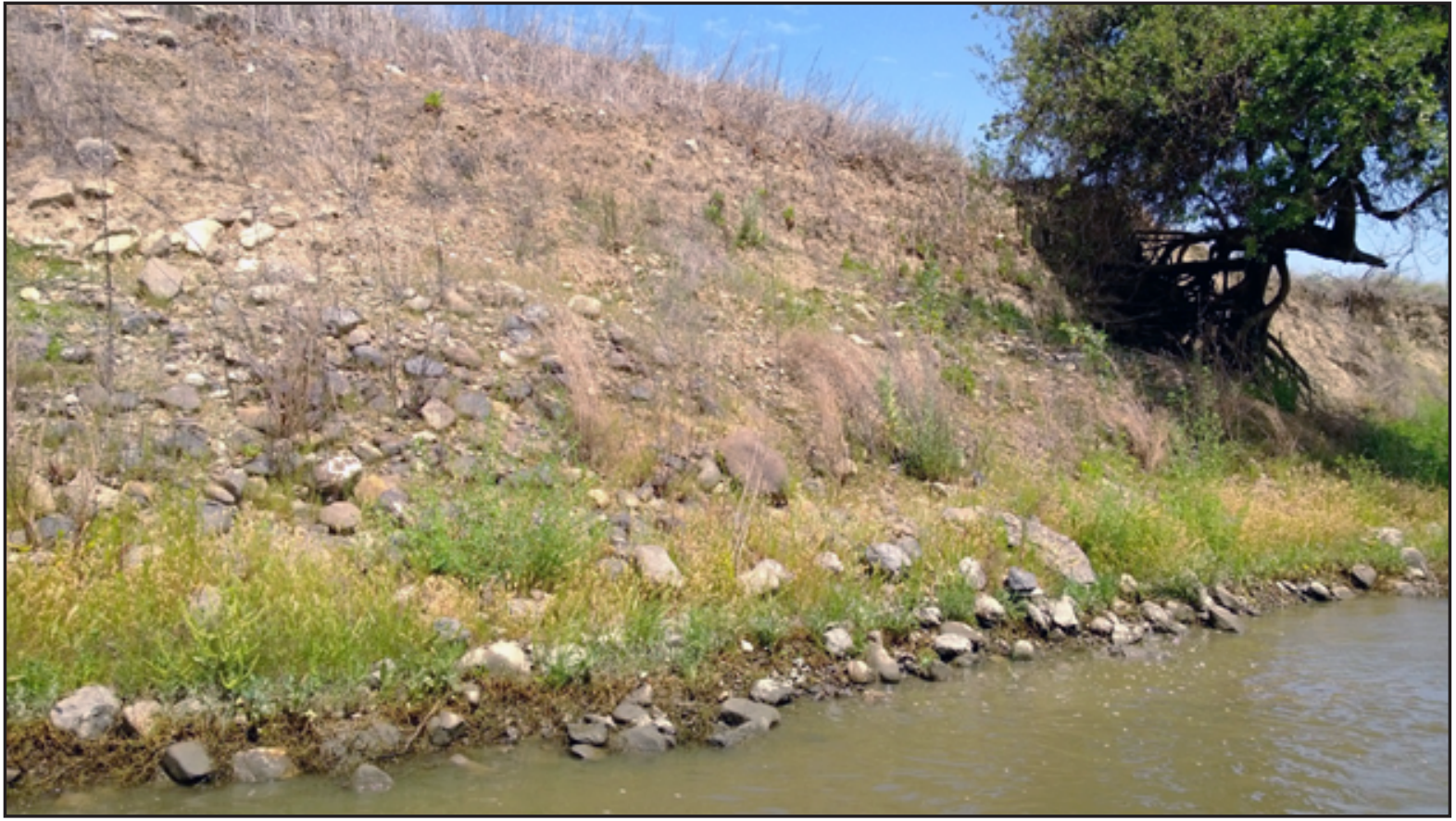

Figure 3. Stones (mostly cobble size), which are used as bank protection in many areas of the lower San Joaquin River, California. 


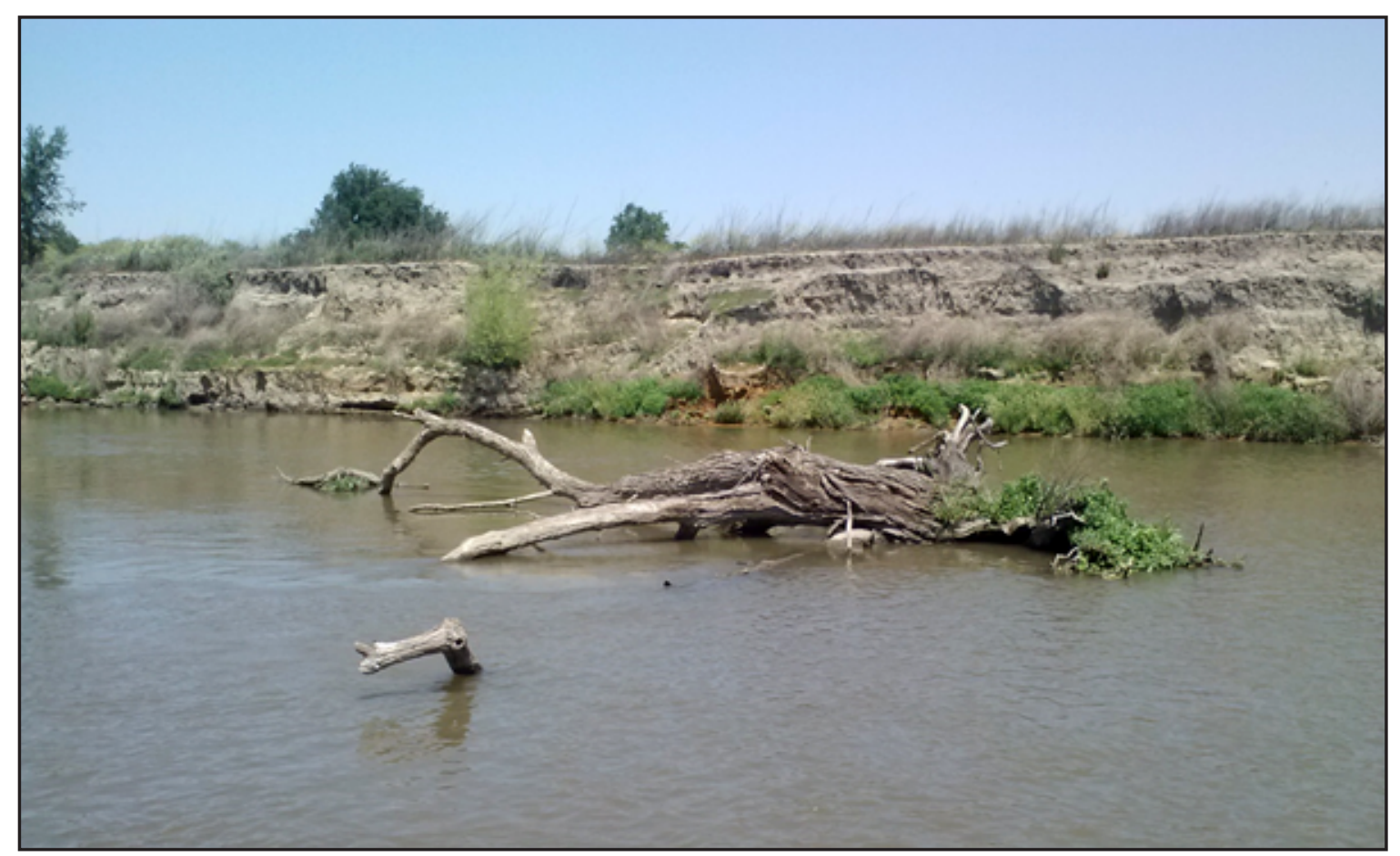

Figure 4. Typical consolidated bank on the lower San Joaquin River, California. The top of the bank in this photo is approximately 2-3 meters above the water surface. A partially submerged, fallen tree is in the foreground.

\section{Study Area, River Reaches, and Subreaches}

The lower San Joaquin River study area extends from the mouth of the Merced River downstream to the USGS streamgage at Vernalis (station 11303500, San Joaquin River near Vernalis, CA), which is on the lower San Joaquin River, downstream from the mouth of the Stanislaus River. The lower San Joaquin River was divided into five reaches for this report. These reach divisions were based on the tributary confluences. The Tuolumne Reach, for example, is the reach of the lower San Joaquin River between the mouths of the Tuolumne River (Rkm 130.6) and the Stanislaus River (Rkm 116.3). The five reaches are shown on the study-area map (fig. 5) and are listed, with their extent in river kilometers, in table 1.

During the 4 years of this study, data were collected throughout the study area, focusing on the reaches with USFWS sampling sites. The USFWS sampled several areas between Rkm 115.2 and 145.3 during 2011 and 2012 (Gruber and others, 2012; Jackson and Van Eenennaam, 2013); the sampling sites were based on pool habitat, water velocity, or previous observations of sturgeon (Jackson and others, 2016). The USFWS collected viable eggs at five sampling sites (Jackson and others, 2016), which can be loosely grouped into three subreaches of the river. The USGS collected data for 3 to 4 years in those three subreaches, whereas in other areas, data were often only collected for 1 or 2 years. The three, primary study-area subreaches are referenced throughout this report, and the locations of these three subreaches (in river kilometers) are listed in table 1.

The subreach sampled farthest downstream is near Sturgeon Bend. The Sturgeon Bend subreach is the section of the lower San Joaquin River generally between the confluence of the Stanislaus River and about $2 \mathrm{~km}$ upstream from the Airport Way Bridge (Rkm 116.3-114.0). Sturgeon Bend is a sharp bend in the lower San Joaquin River, which is popular with local fisherman. The second-most downstream subreach is the Old Fisherman's Club subreach, between Finnegan Cut ( Rkm 127.5) and the upstream end of the straight channel next to Highway 132 (Rkm 125.2), next to the Old Fisherman's Club, a private sportsman's club on the east bank of the lower San Joaquin River. The third subreach is near Grayson Bridge between the Grayson Road Bridge (Rkm 139.9) and $\mathrm{Rkm}$ 137.3. The locations (in river kilometers) of other selected landmarks and geographical features are listed in table 2 . 


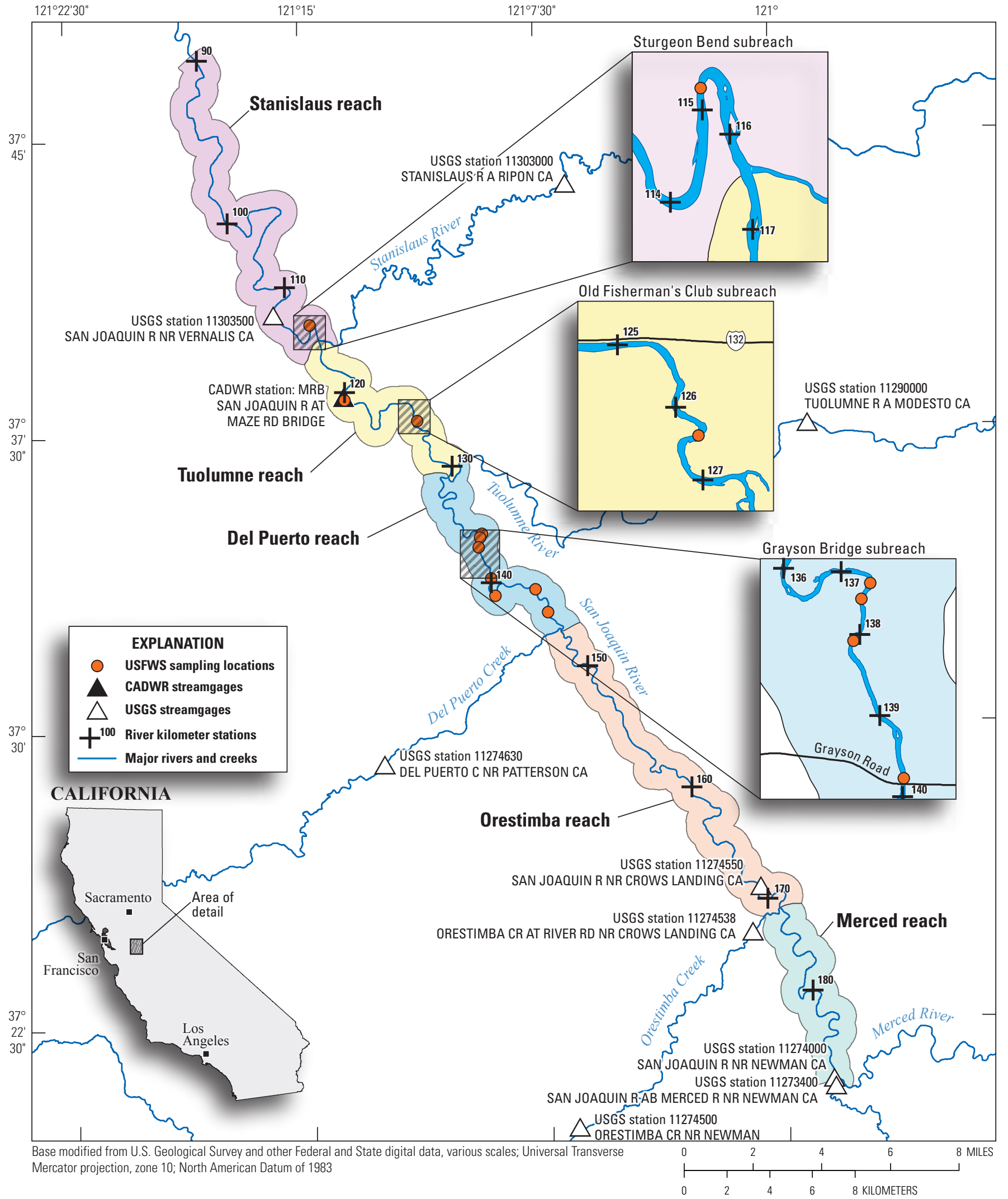

Figure 5. Lower San Joaquin River reaches, subreaches of interest (shown in three upper-right inset maps), locations of selected U.S. Geological Survey (USGS) and California Department of Water Resources (CADWR) streamgages, river kilometer stations, and 2011-12 U.S. Fish and Wildlife Service (USFWS) sturgeon-egg sampling sites. 
Table 1. River reaches and subreaches of the lower San Joaquin River and the respective downstream and upstream river kilometer stations.

[River station based on channel configuration during 2012 National Aerial Imagery Program aerial imagery.]

\begin{tabular}{lcc}
\hline \multirow{2}{*}{ Reach or subreach name } & \multicolumn{2}{c}{ River kilometer } \\
\cline { 2 - 3 } & Downstream & Upstream \\
\hline Stanislaus reach & 85.1 & 116.3 \\
Tuolumne reach & 116.3 & 130.6 \\
Del Puerto reach & 130.6 & 146.3 \\
Orestimba reach & 146.3 & 171.8 \\
Merced reach & 171.8 & 187.6 \\
Sturgeon Bend subreach & 114.0 & 116.3 \\
Old Fisherman's Club subreach & 125.2 & 127.5 \\
Grayson Bridge subreach & 137.3 & 139.9 \\
\hline
\end{tabular}

Table 2. Selected landmarks and geographical features along the lower San Joaquin River, by river kilometers and geographical coordinates.

[River stationing based on channel configuration during 2012 National Aerial Imagery Program aerial imagery. North American Datum of 1983. Easting and northing are map grid coordinates based on Universal Transverse Mercater projection, zone 10N. Abbreviations: dd, decimal degrees; Rkm, river kilometer]

\begin{tabular}{lccccc}
\hline \multicolumn{1}{c}{ Feature } & Rkm & $\begin{array}{c}\text { Latitude } \\
\text { (dd) }\end{array}$ & $\begin{array}{c}\text { Longitude } \\
\text { (dd) }\end{array}$ & $\begin{array}{c}\text { Northing } \\
\text { (meters) }\end{array}$ & $\begin{array}{c}\text { Easting } \\
\text { (meters) }\end{array}$ \\
\hline Confluence with Sacramento River & 0.2 & 38.065 & -121.854 & 4213606 & 600512 \\
Bifurcation with Old River & 85.1 & 37.808 & -121.327 & 4185838 & 647272 \\
Mossdale Bridge & 89.6 & 37.786 & -121.307 & 4183410 & 649098 \\
Sacramento River at Vernalis, station 11303500 & 111.8 & 37.676 & -121.265 & 4171294 & 652968 \\
Airport Way Bridge & 111.9 & 37.676 & -121.265 & 4171254 & 652984 \\
Confluence with Stanislaus River & 116.3 & 37.665 & -121.242 & 4170130 & 655080 \\
Maze Boulevard/Highway 132 Bridge & 120.2 & 37.641 & -121.229 & 4167489 & 656276 \\
Old Fisherman's Club, boat launch & 125.5 & 37.637 & -121.193 & 4167049 & 659430 \\
Finnegan Cut & 127.5 & 37.626 & -121.185 & 4165832 & 660166 \\
Confluence with Toulumne River & 130.6 & 37.606 & -121.174 & 4163701 & 661154 \\
West Stanislaus Main Canal & 131.1 & 37.605 & -121.178 & 4163599 & 660851 \\
Laird Slough & 136.4 & 37.581 & -121.165 & 4160866 & 662013 \\
Grayson Road Bridge & 139.9 & 37.563 & -121.152 & 4158891 & 663185 \\
Laird Park (upstream end) & 142.0 & 37.560 & -121.146 & 4158595 & 663752 \\
Del Puerto Creek confluence & 146.3 & 37.543 & -121.116 & 4156782 & 666458 \\
Las Palmas boat launch & 154.4 & 37.498 & -121.083 & 4151867 & 669490 \\
East Las Palmas Avenue Bridge & 154.9 & 37.494 & -121.081 & 4151383 & 669669 \\
Crow's Landing Road & 169.0 & 37.431 & -121.013 & 4144592 & 675768 \\
Orestimba Creek confluence & 171.8 & 37.422 & -121.003 & 4143571 & 676686 \\
Confluence with Merced River & 187.6 & 37.349 & -120.975 & 4135530 & 679341 \\
\hline
\end{tabular}




\section{Hydrology}

Streamflow in the lower San Joaquin River is dependent on a combination of natural and engineered controlsclimate, upstream dam regulation, diversions and return flows for agriculture and domestic water use, and reservoir releases for ecological purposes. The San Joaquin Basin has a drainage area of about 40,000 square kilometers (not including the Tulare Basin). Climate in the San Joaquin Valley is characterized by hot, dry summers and cool, mild winters, but annual precipitation is highly variable from year to year. Average annual precipitation in the valley floor is approximately 200 millimeters per year ( $\mathrm{mm} / \mathrm{yr}$ ), but precipitation in the western slopes of the Sierra Nevada can exceed $1300 \mathrm{~mm} / \mathrm{yr}$ (National Oceanic and Atmospheric Administration, 1985). The storms producing the greatest amount of precipitation result from extratropical cyclones (Dettinger and others, 2011), commonly referred to as "atmospheric rivers".

Streamflow in all major tributary rivers is regulated by upstream dams, the largest of which are Friant Dam on the San Joaquin River, built in 1949; New Exchequer Dam on the Merced River, completed in 1967; New Don Pedro Dam on the Tuolumne River, completed in 1971; and New Melones Dam on the Stanislaus River, completed in 1978, which have capacities of 0.64 cubic kilometers $\left(\mathrm{km}^{3}\right), 1.26 \mathrm{~km}^{3}, 2.50 \mathrm{~km}^{3}$, and $2.96 \mathrm{~km}^{3}$, respectively. The latter three dams were built over smaller, existing dams - the Exchequer, Don Pedro, and Melones Dams - that had capacities of $0.35 \mathrm{~km}^{3,} 0.37 \mathrm{~km}^{3}$, and $0.14 \mathrm{~km}^{3}$, respectively. The dams were built for water storage and flood control. They are able to capture much of the runoff from small- to mid-size storms, but do not have storage capacities great enough to capture all of the runoff from the largest storms.

Since the construction of dams in the San Joaquin River Basin, peak flows are usually less than natural flows before dam completion, as shown in the records of the peak annual streamflow for the four major tributary rivers (fig. 6). In figure 6 , the completion date of major dam construction on each river is indicated, along with peak annual streamflow, recorded as discharge at selected streamgages, upstream from the dams. The upstream gages are mostly at the outlet of smaller watersheds; therefore, these records do not represent total natural flow or total inflow to the dam. Nevertheless, a comparison of the upstream and downstream peak annual streamflow records showed that many of the peak flows in the upstream hydrograph were absent or attenuated in the downstream hydrograph. Streamflows in Orestimba and Del Puerto Creeks are not regulated by dams.
The alterations in natural flow due to dam construction also were noticeable in daily mean discharge data from the USGS streamgage (San Joaquin River at Vernalis, Station 11303500; fig. 7). Daily mean streamflow records for water years ${ }^{1}$ (WYs) 1924 and 1930-2014 were divided into two groups: pre-1967 and post-1967 (figs. 7A, $B$ ). The records were divided this way on the basis of the completion date (September 1966) of the New Exchequer Dam on the Merced River, which was the first of the "second-generation" dams constructed. In each plot, the records are grouped by hydrologic water-year type. The California Department of Water Resources (California Department of Water Resources, 2015) has categorized each WY from 1901 through 2014 for the San Joaquin Valley on the basis of unimpaired runoff volumes (State Water Resources Control Board, 1995). There are five types of water years in this hydrological classification system, ranging from wettest to driest: "wet," "above normal," "below normal," "dry," and "critical." During a "wet" year, runoff is equal to or greater than 3.8 million acre-feet (MAF); for "above-normal," runoff is greater than 3.1 MAF and less than 3.8 MAF; for "below normal," runoff is equal to or less than 3.1 MAF and greater than 2.5 MAF; for "dry," runoff is equal to or less than 2.5 MAF and greater than 2.1 MAF; and for "critical," runoff is equal to or less than 2.1 MAF.

On average, the peak flows in post-1967 wet years were only slightly lower and arrived a little earlier than in pre1967 wet years (the average of all wet years and average of all above normal years are shown as bold lines in figures $7 \mathrm{~A}$ and $7 B$ ). During above-normal years, peak flows between April and June were notably lower after WY 1967, and during below-normal years, peak flows were essentially absent following dam construction, reflecting storage of water from snowmelt in reservoirs behind the dams during those wateryear types. The altered hydrologic regime of the lower San Joaquin River following dam construction resulted in fewer and smaller high flows than before the dams were in place. This likely decreased the sediment transport capacity of the river as well.

During this study, data were collected over a range of water-year types - from wet in 2011 and dry in 2012 to critical in 2013 and 2014. The daily mean streamflow in the San Joaquin River, measured as discharge by the USGS streamgage at Vernalis (station 11303500), is shown for water years 2011-14 in figure 8 . The minimum and maximum mean daily discharge (1923 to 2014) is also shown in figure 8 to compare the 4 water years of this study to the historical range.

\footnotetext{
${ }^{1} \mathrm{~A}$ water year is the 12 -month period from October 1 to September 30 . It is designated by the calendar year in which it ends.
} 


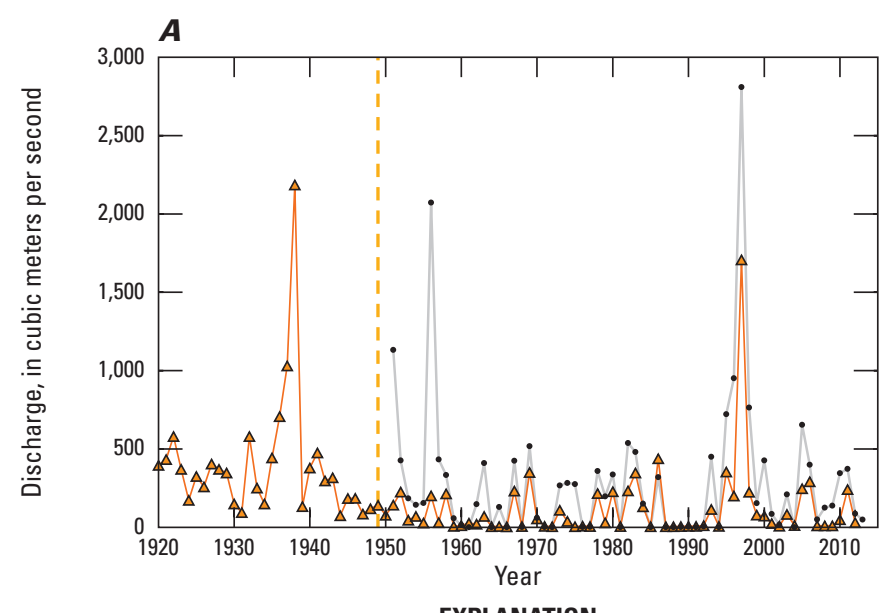

EXPLANATION

$\triangle-$ San Joaquin River below Friant (11251000)

- San Joaquin River upstream from Willow Creek near Auberry (11242000) - - Friant Dam

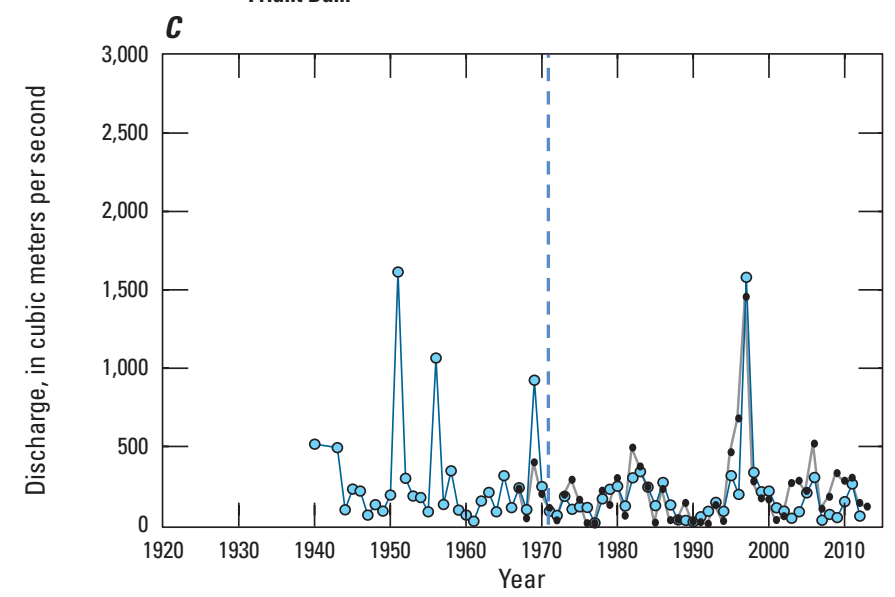

EXPLANATION

$-0-$ Tuolumne River at Modesto, CA (11290000)

- Combination of Cherry Creek and upstream Tuolumne-Cherry Creek

Cherry Creek near Early intake, CA (11278300) and Tuolumne River below Early intake near Mather, CA (11276900)

- - New Don Pedro Dam (Tuolumne River)

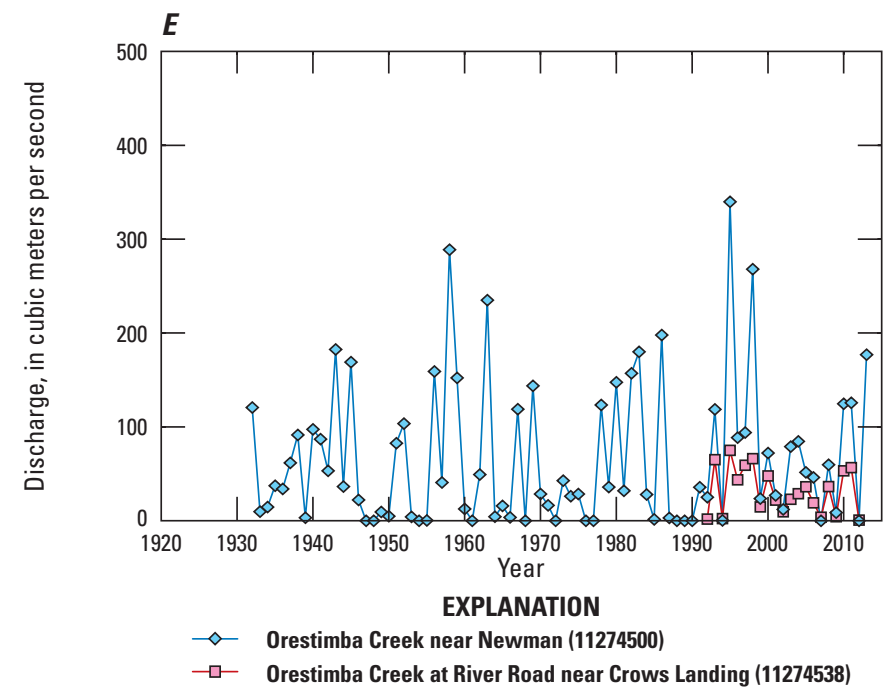

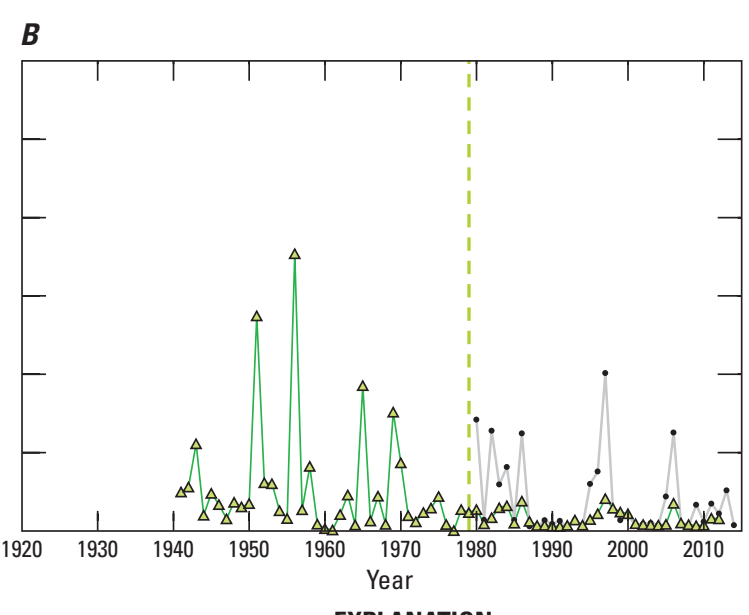

EXPLANATION

$\triangle$ Stanislaus River at Ripon, CA (11303000)

- North Fork Stanislaus River near Avery, CA (11294500)

_ - New Melones Dam (Stanislaus River)

D

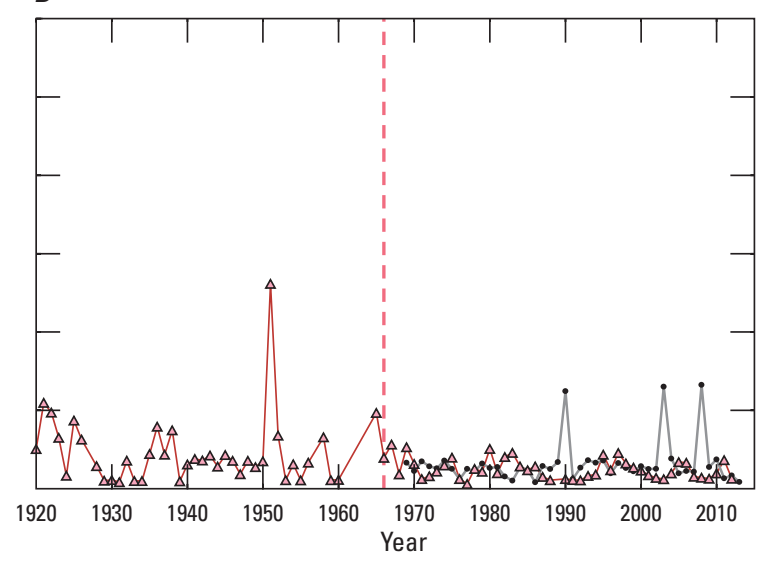

EXPLANATION

$\triangle$ Merced River below Merced Falls Dam near Snell, CA (11270900)

- Merced River at Pohono Bridge near Yosemite, CA (11266500)

- - New Exchequer Dam (Merced)

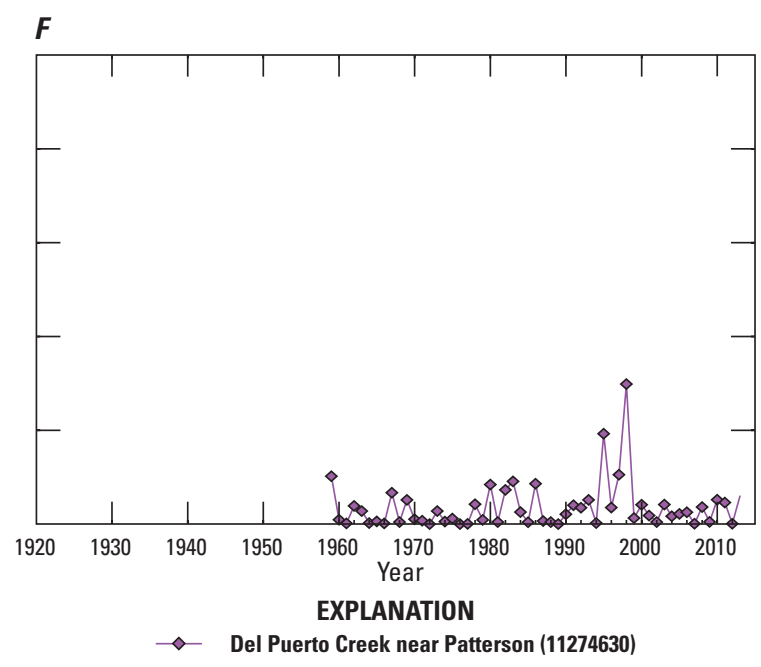

Figure 6. Annual peak streamflow, measured as instantaneous discharge at selected streamgages, and the time of dam completion, where applicable, for the following rivers and creeks in the San Joaquin Basin, California, 1920-2010: $A$, San Joaquin River; $B$, Stanislaus River; $C$, Tuolumne River; $D$, Merced River; $E$, Orestimba Creek; and F, Del Puerto Creek. 

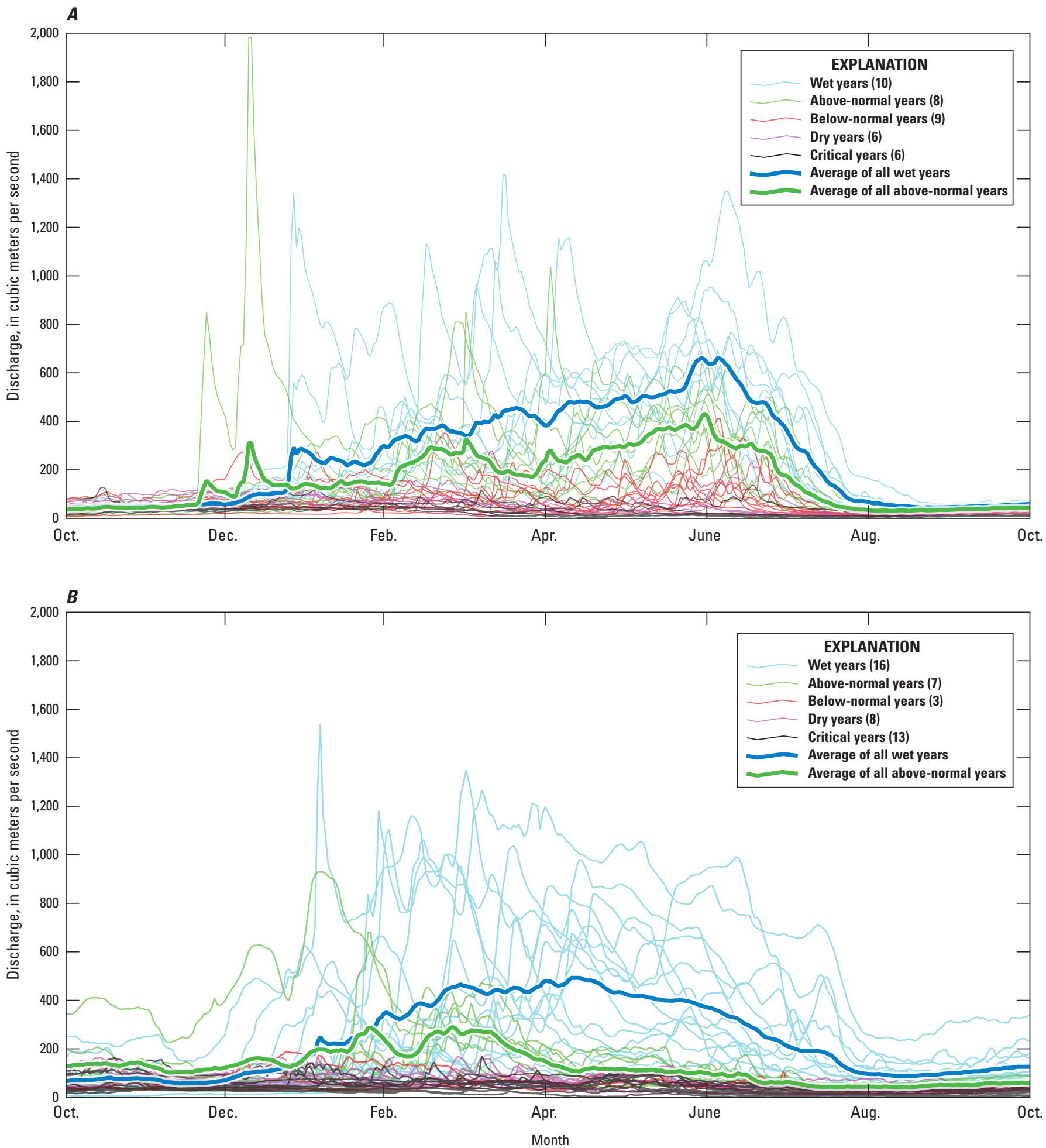

Figure 7. Daily average streamflow, measured as discharge at the U.S. Geological Survey streamgage at Vernalis (station 11303500), for the lower San Joaquin River, California, categorized by water-year type (California Regional Water Quality Control Board, 1989) for water years $A, 1924,1930-67$; and $B, 1968-2014$. Five types of water years were classified hydrologically on the basis of annual runoff (RO): in a "wet" water year, RO is equal to or greater than 3.8 million acre-feet (MAF); in an "above-normal" water year, RO is greater than 3.1 MAF and less than 3.8 MAF; in a "below normal" water year, RO is equal to or less than 3.1 MAF and greater than 2.5 MAF; in a "dry" water year, RO is equal to or less than $2.5 \mathrm{MAF}$ and greater than $2.1 \mathrm{MAF}$; and in a "critical" water year, RO is equal to or less than 2.1 MAF. The number in parenthesis is the number of years included in that water year category. 


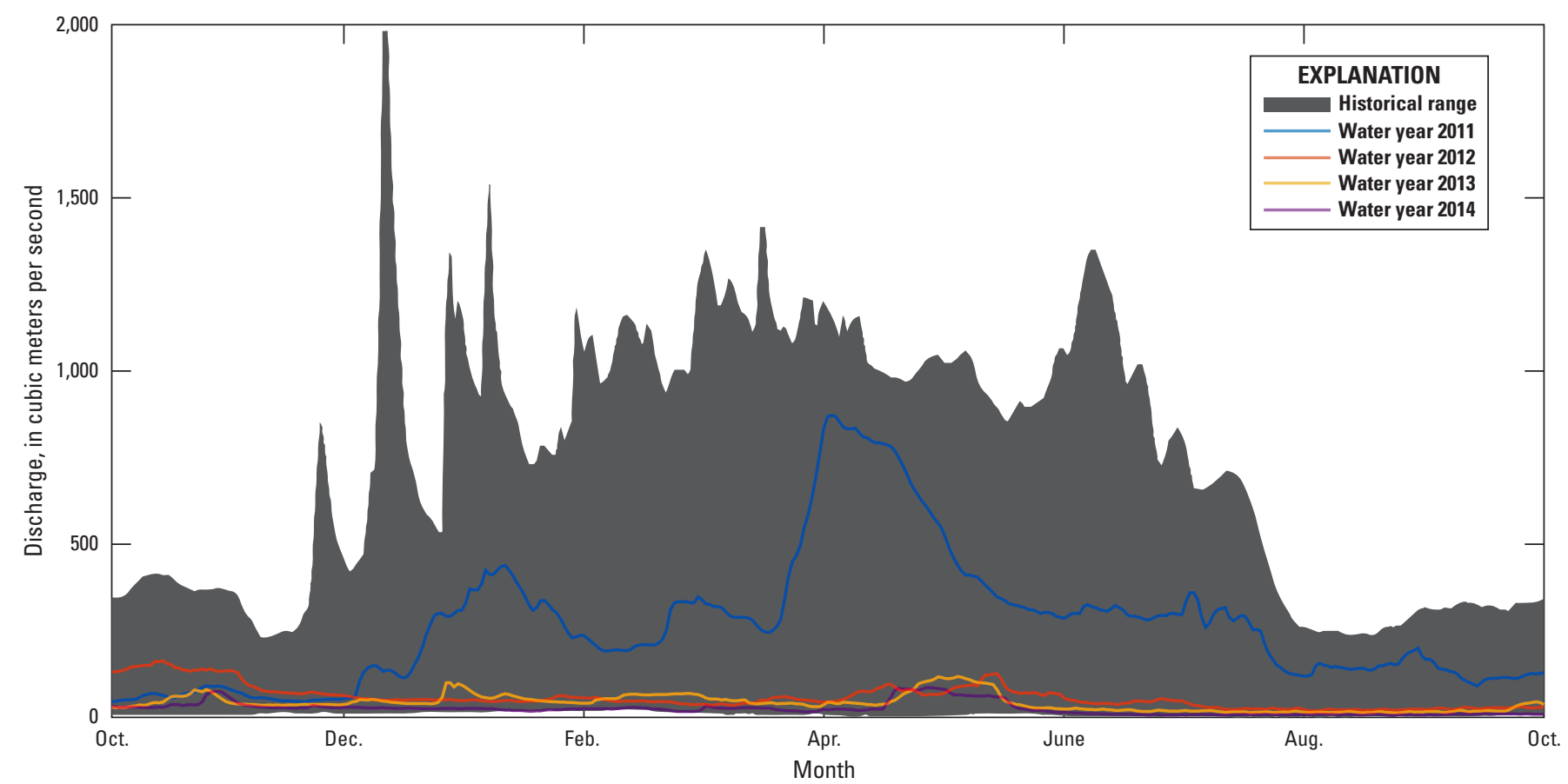

Figure 8. Daily mean streamflow, measured as discharge, during the study (water years 2011-14) relative to the historical range of discharge measured on the San Joaquin River, California, at the U.S. Geological Survey streamgage at Vernalis (station 11303500).

\section{White Sturgeon Ecology}

White sturgeon inhabit estuaries and rivers along the west coast of North America. They can live up to 100 years and often reach 2.5 meters $(\mathrm{m})$ in length, although they can grow much larger (Moyle, 2002). White sturgeon are known to spawn in only three major river systems on the west coast: the Fraser, Columbia, and Sacramento-San Joaquin (Committee on the Status of Endangered Wildlife in Canada, 2012). They are generally considered diadromous because adults can live in fresh and salt water, but must spawn in freshwater. There is some evidence that adult white sturgeon stay in freshwater estuaries and do not venture out to the ocean (Veinott and others, 1999). There have also been cases, however, where individual sturgeon from the three major river systems were found in a different river system than the one in which they spawned (Nelson and others, 2004; Welch and others, 2006), and white sturgeon have been occasionally found in other systems, such as the Klamath River (Moyle, 2002). Adult Sacramento-San Joaquin white sturgeon spend most of their time in the San Francisco Bay estuary and migrate upstream in the spring to spawn (Schaffter, 1997). The juvenile fish can spend several years in the river channel before slowly migrating downstream to the estuary (Klimley and others, 2015).

Sturgeon are broadcast spawners that release eggs and sperm in fast moving water to disperse the eggs over a wide area (Conte and others, 1988). The location and timing of white sturgeon spawning are not well understood, but it is generally thought that the sturgeon respond to increases in streamflow (Schaffter, 1997; Hildebrand and others, 1999; Paragamian and Wakkinen, 2011). They select areas in the channel that have the highest water velocity (Parsley and others, 1993; Parsley and Beckman, 1994; Billard and Lecointre, 2000). In the Kootenai River, for example, white sturgeon have only been found spawning in areas that have a mean water-column velocity of $0.8-2.8$ meters per second (m/s; Parsley and others, 1993).

Sturgeon might choose areas with high water velocity because the bed material typical of such locations can increase the survival of eggs and larva. The type of bed material is important to white sturgeon because when the eggs make contact with freshwater, the eggs' outermost layer forms a thin adhesive coating that allows the eggs to adhere to the bed material (Conte and others, 1988). Eggs adhering to clean, coarse sediment (such as gravel or cobble) have better oxygenation (Kock and others, 2006). The eggs can adhere to other surfaces, such as bedrock, boulders, woody debris, submerged aquatic vegetation, or sand (Parsley and Kofoot, 2013). If the eggs are buried under as little as 2 millimeters $(\mathrm{mm})$ of fine-grain sediment, however, mortality increases (Kock and others, 2006; Paragamian and others, 2009; Parsley and Kofoot, 2013). Viable eggs with a thin coating of sand have been documented in the lower San Joaquin River by Jackson and Van Eenennaam (2013) and in the Kootenai River by Paragamian (2012). Eggs can still develop if they land on sand-size bed material, but because sand is often highly mobile in a river, it is more likely for the egg to be buried and not survive. 
The bed-material type can also play an important role in survival at the larval life stage of sturgeon. Larvae hide from predators in the interstitial spaces of gravels and cobbles, but tend to drift over surfaces such as sand or cobble embedded with sand (McAdam, 2011), which can lead to increased predation (Gadomski and Parsley, 2005). High water velocity $(1.2-6.0 \mathrm{~m} / \mathrm{s})$ and channel depths greater than $1.8 \mathrm{~m}$ are thought to be characteristics of the preferred habitat for white sturgeon spawning (Gard, 1996).

Dams on river systems can adversely affect sturgeon populations (Rochard and others 1990; Parsley and Beckman, 1994). Dam construction can result in disconnection of habitat or isolation of individuals or subpopulations. Flow regulation from dams also cause downstream effects associated with diminished peak flows, such as seasonal decreases in water velocity, water depth, supply of coarse bed material, and sediment transport; thus, a long-term downstream effect of flow regulation by dams is a change in bed-material composition (Kondolf, 1997). Diminished peak flows could have affected the bed-material composition in many traditional white sturgeon spawning grounds. In the Kootenai River, for example, biologists have repeatedly observed that white sturgeon spawn in sand-bedded areas where cobble and gravel are buried beneath a meter or more of sand (Barton, 2004). Paragamian and others (2009) suggested that flow regulation at the upstream dam of the Kootenai River altered the sediment-transport regime and caused deposition of sand over traditional spawning areas, which sturgeon were selecting because of water velocity rather than bed-material type. Changes in land use and flow regulation due to upstream dam operations have notably altered the flow regime in the Sacramento-San Joaquin River system.

\section{White Sturgeon Monitoring in the San Joaquin River by the U.S. Fish and Wildlife Service}

In the spring of 2011, the USFWS used egg mats at eight locations to monitor spawning activity by white sturgeon (fig. 9B). At Rkm 142, 15 eggs were found on April 25, 2011, and another 4 eggs were found on April 28, 2011 (Gruber and others, 2012). The following year, egg mats were deployed at five locations: Rkm 115.2, 126.4, 137.6, 139.9, and 139.8 (fig. 9C). Viable eggs were found at all five locations between March and May 2012 (Jackson and Van Eenennaam, 2013). The river discharge on dates of the 2011-12 USFWS egg collection and of the USGS data collection are shown in figure $9 A$. Additional details about the USFWS white sturgeon monitoring are in Jackson and others (2016).

\section{Study Methods}

The equipment and methods used to collect data and samples to document the physical characteristics (water velocity, water depth, and bed-material sediment size) of the lower San Joaquin River are described in this section. Data generally were collected in the spring of each year from 2011 to 2014 .

\section{Vertical and Horizontal Datum}

Elevation data were referenced to the North American Vertical Datum of 1988 (NAVD 88). Horizontal data are reported in grid coordinates of the Universal Transverse Mercator (UTM) projection, using the North American Datum of 1983 (NAD 83); the study area is in UTM zone 10 north.

\section{River-Centerline Convention}

Data and locations in this report are often referenced to a river-centerline coordinate system. A river centerline is a continuous line starting at the receiving water body, and it generally follows the middle of the channel, as delineated during typical low-flow periods. A river-centerline coordinate system measures distance along the centerline. Although some early USGS topographic maps show centerline coordinates in river miles, the course of the river has changed substantially; therefore, a new river centerline and coordinate system were defined for this study.

To create the river-centerline coordinate system, first, the wetted area of the river was digitized from the 2012 National Aerial Imagery Program (NAIP) orthorectified aerial imagery of the lower San Joaquin River. Next, a continuous line was drawn in the upstream direction tracing the course of the river in the center of the wetted area. In areas containing multiple channels or large islands, the centerline was drawn though the center of the widest channel. Although the study period includes samples and data collected during 2011-14, the channel configuration did not appear to change much in aerial imagery acquired between 2011 and 2014.

In most coordinate systems, distances are measured from the origin, or zero point. For the river centerline, stationing begins in the center of the channel of the downstream receiving water. For the San Joaquin River, the downstream receiving water is the Sacramento River; therefore, the junction of their centerlines was designated as the river kilometer origin, or $\mathrm{Rkm} 0$. The geographical coordinates for each station at 1-Rkm intervals on the centerline of the lower San Joaquin River (Rkm 0-187) are provided in appendix table 1-1 in this report and are available online (Marineau and others, 2016). The river kilometer of selected landmarks and geographical features referenced in this report are provided in table 2 . 

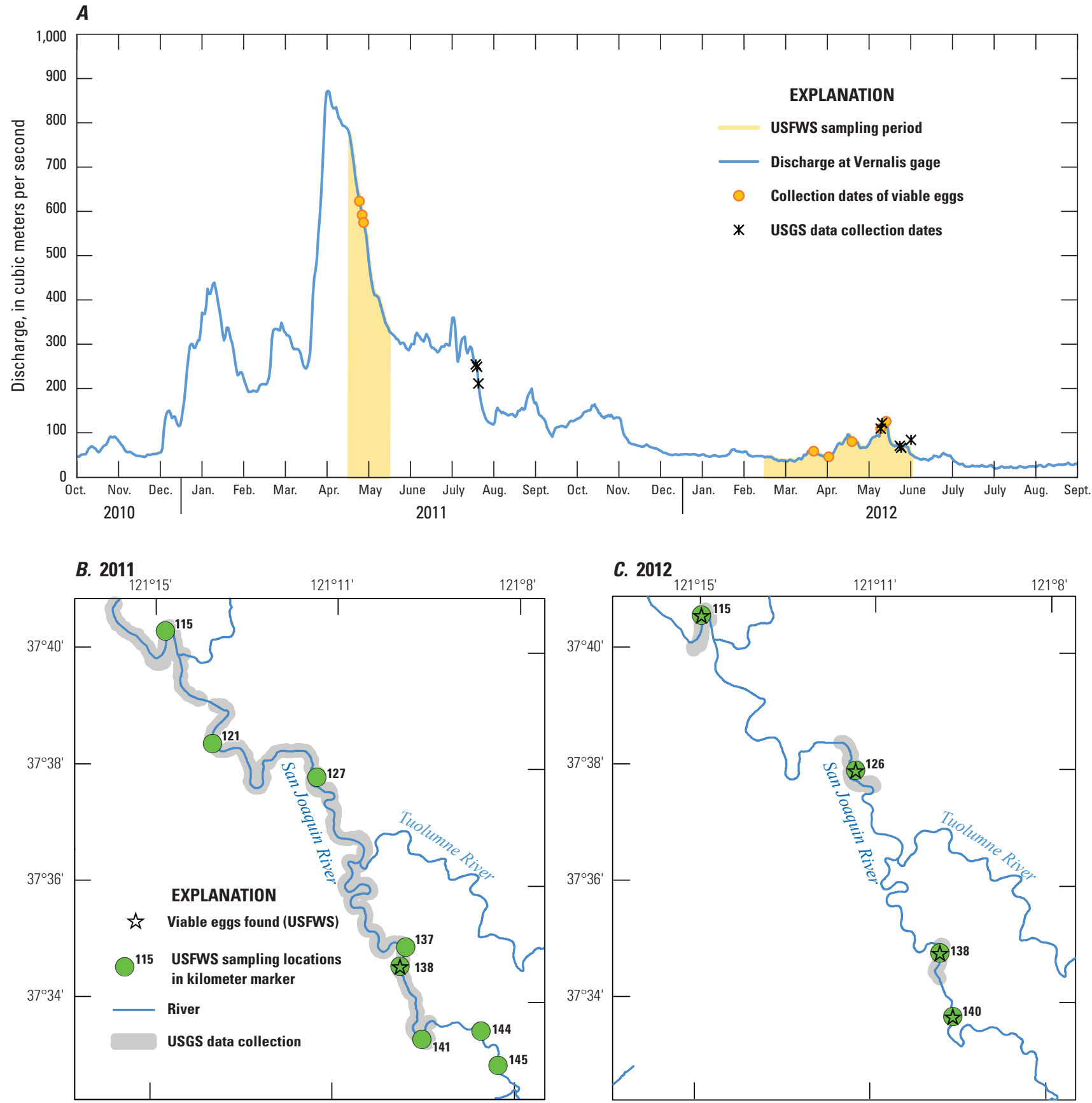

Base modified from U.S. Geological Survey and other Federal and State digital data, various scales; Albers Equal Area Conic projection, standard parallels are $29^{\circ} 30^{\prime \prime}$ and $45^{\circ} 30^{\prime \prime}$ : North American Datum of 1983

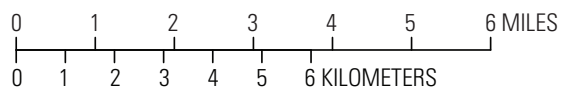

Figure 9. Dates and locations of the U.S. Fish and Wildlife Service (USFWS) sampling and U.S. Geological Survey (USGS) data collection, 2011-12: A, Hydrograph of discharge for San Joaquin River at USGS streamgage at Vernalis, California (station 11303500) and discharge on the dates when viable white sturgeon eggs were collected by the USFWS and the USGS collected data. The USFWS sampling locations and extent of the USGS data collection; B, 2011; and C, 2012. 


\section{Equipment}

The following is a list of equipment used during the data collection and sampling.

- 19-foot (ft) Koffler aluminum boat with outboard jet motor.

- 9.4-ft West Marine high-density polyethylene boat with 4-horsepower outboard motor.

- Odom $^{\mathrm{TM}}$ multibeam echosounder system.

- SonTek ${ }^{\circledR}$ RiverSurveyor ${ }^{\mathrm{TM}}$ M9 acoustic Doppler current profiler (ADCP).

- SonTek real-time kinematic global positioning system (RTK-GPS).

- Teledyne RD Instruments Rio Grande ${ }^{\mathrm{TM}}$ ADCP.

- Field laptop with SonTek HydroSurveyor ${ }^{\mathrm{TM}}$ and WinRiver II ${ }^{\mathrm{TM}}$ software.

- Trimble R10 Global Navigation Satellite System (GNSS) receiver mounted to the boat used with a realtime network global positioning system (RTN-GPS).

- Trimble TSC3 hand-held controller, used to program the GNSS receiver and to record data.

- Humminbird ${ }^{\mathrm{TM}}$ 1198c SI Combo side-scanning sonar.

- US BMH-62 bed-material sampler.

Additional details (specifications, operation, and so forth) on the multibeam echosounder system, the ADCP equipment, and the side-scanning sonar follow.

\section{Multibeam Echosounder System}

High-resolution bathymetric data were collected in all four subreaches in 2011 using an Odom ${ }^{\mathrm{TM}}$ multibeam echosounder system. The multibeam system included a sonar head that operated at 240 kilohertz $(\mathrm{kHz})$ and collected soundings over a 120-degree swath. The geolocation of the sonar head was determined with a global positioning system (GPS) receiver, which also recorded the heading or direction of travel. A motion reference unit (MRU) mounted directly behind the sonar head was used to precisely measure the orientation of the sonar head and the angle of the sonar beams. A sound-velocity sensor was mounted near the sonar head to measure the speed of sound at the head, data needed to form the received beam correctly. Data streams from the GPS, MRU, sound-velocity sensor, and sonar were integrated and processed using a computer running the hydrographic survey software. The system was mounted, tested, and calibrated in the field on July 25,2011 . The calibration involved determining the precise pitch, roll, and yaw angle offsets each time the system was mounted to a boat.

\section{Acoustic Doppler Current Profiler}

Water velocity and depth measurements were collected using two types of boat-mounted ADCPs. In 2011, 2012, and 2014, data were collected using a SonTek ${ }^{\circledR}$ M9 ADCP, and in 2013, data were collected using a Teledyne RD Instruments, Inc. (RDI), Rio Grande ${ }^{\mathrm{TM}} \mathrm{ADCP}$. Depth-averaged velocity was calculated from the vertical profiles measured by the ADCPs.

In general, both instruments collect the same type of data (water velocity, depth, and instrument position). The SonTek M9 is equipped with one center-mounted, downwardfacing transducer ( 0.5 megahertz, or $\mathrm{MHz}$ ), which measured the distance to the streambed, and two sets of four, equally spaced transducers mounted around the center transducer at an outward-slant angle. The two sets of transducers collect measurements at higher frequencies of $1.0 \mathrm{MHz}$ and $3.0 \mathrm{MHz}$, respectively. The M9 ADCP automatically alternated between each set of transducer heads according to the detected water depth when in automatic adjustment mode. The RDI Rio Grande has a single set of four slant-mounted transducers operating at $1.2 \mathrm{MHz}$, with no vertical beam.

Horizontal positions were measured using a differential GPS, an RTK-GPS, or an RTN-GPS. In 2011, coordinates were measured using a differential GPS. In 2012, a SonTek RTK-GPS was used. As deployed, this RTK-GPS system only provided positions in a local reference system. In 2013, an RDI, Inc., differential GPS was used with the RDI Rio Grande $^{\mathrm{TM}}$ ADCP. Finally, in 2014, a Trimble R10 RTN-GPS was used while taking measurements with the SonTek M9 ADCP.

Each ADCP used for this study was mounted to the side of the boat using an aluminum bracket, such that the instrument was submerged to a depth of 35 centimeters $(\mathrm{cm})$ and was calibrated daily. Depth-averaged velocity was computed by RiverSurveyor Live for the SonTek M9 ADCP and WinRiver II for the RDI Rio Grande ADCP.

\section{Side-Scanning Sonar}

We used a Johnson Outdoors Marine Electronics, Inc., Humminbird $^{\mathrm{TM}} 1198 \mathrm{c}$ SI Combo side-imaging sonar to collect side-scan sonar data. This instrument features two sidelooking beams, one downward-looking beam, and a GPS receiver. The transducer was mounted to an adjustable-depth, hinged, aluminum bracket that was fixed to the transom of the motorized boat. The transducer was typically lowered to a depth of about $70 \mathrm{~cm}$ to avoid interference from "prop wash" from the primary boat engine; however, it was often raised up to a depth of only about $25 \mathrm{~cm}$ in shallow areas. At these times, the primary motor was raised, and only the smaller boat engine was used for propulsion. The side-imaging transducers operate at frequencies of $455 \mathrm{kHz}$ or $800 \mathrm{kHz}$, whereas the downward-looking beam operates at $83 \mathrm{kHz}$ or $200 \mathrm{kHz}$. The frequency of the side-imaging transducers was set to $455 \mathrm{kHz}$, as recommended by Kaeser and others (2012). Maximum range of the side-imaging transducers was adjusted in the field 
on the basis of channel width to obtain optimal coverage and resolution of the entire channel. This distance was usually set at 20-30 meters.

\section{Data Collection}

This section describes the methods used to collect data and analyze samples for this study. Water depth was measured by soundings using a multibeam sonar and an ADCP. Bedform imagery was collected using a side-scan sonar. Efforts to map streambed material using the side-scan sonar images and ADCP backscatter-intensity data are discussed in this section. Bed-material sampling and processing are also described in this section.

\section{Water Depth and Velocity Measurements using Acoustic Doppler Current Profiler, 2011-14}

The locations of hydroacoustic data collection for each year are listed in table 3 and shown in figure 10 . Locations of data collection varied from year to year, based on conversations with USFWS biologists and as more information became available about the geomorphology of the river. In 2011, ADCP data were collected between Laird Park and the USGS streamgage at Vernalis (station 11303500) at Rkm 111.8 (fig. 10A). In 2012, data collection focused on the three subreaches: Sturgeon Bend, Old Fisherman's Club, and Grayson Bridge (fig. 10B). In 2013, although lowflow conditions limited access to many areas, the data were collected for the same reach as in 2011, for small portions of the Tuolumne and Stanislaus Rivers, and for part of the Orestimba reach (fig. 10C). In 2014, a smaller boat was used to improve access, but low-flow conditions still presented a challenge and limited access to many parts of the river. Data collection in 2014 included the Sturgeon Bend subreach, the Del Puerto reach, and a small part of the Orestimba reach (fig. 10D).

Depth and velocity data were collected using two different approaches: channel cross sections and longitudinal profiles. A combination of channel cross sections and longitudinal profiles were collected in 2011 and 2012, and also in limited areas in 2014. In 2013, only longitudinal profiles were collected in order to cover large areas quickly.

Table 3. Summary of hydroacoustic data collection sites, including daily mean streamflow, measured as discharge, in the reach during data collection and the exceedance probability of that discharge.

[Hydroacoustic data collection sites (and Rkm locations) refer to the San Joaquin River, California, except where otherwise indicated. Abbreviations: mm/dd/ yyyy, day/month/year; $\mathrm{m}^{3} / \mathrm{s}$, cubic meters per second]

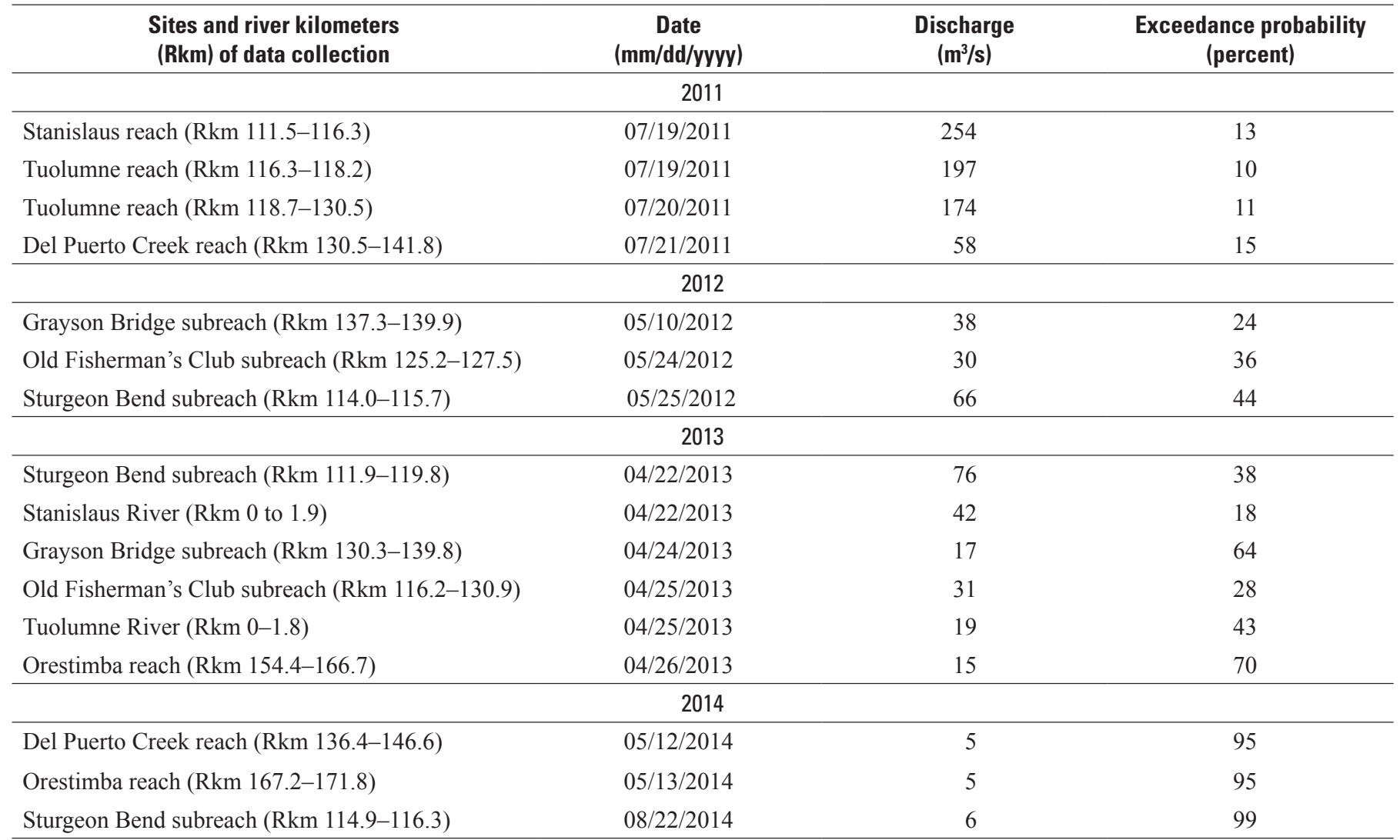


A. 2011

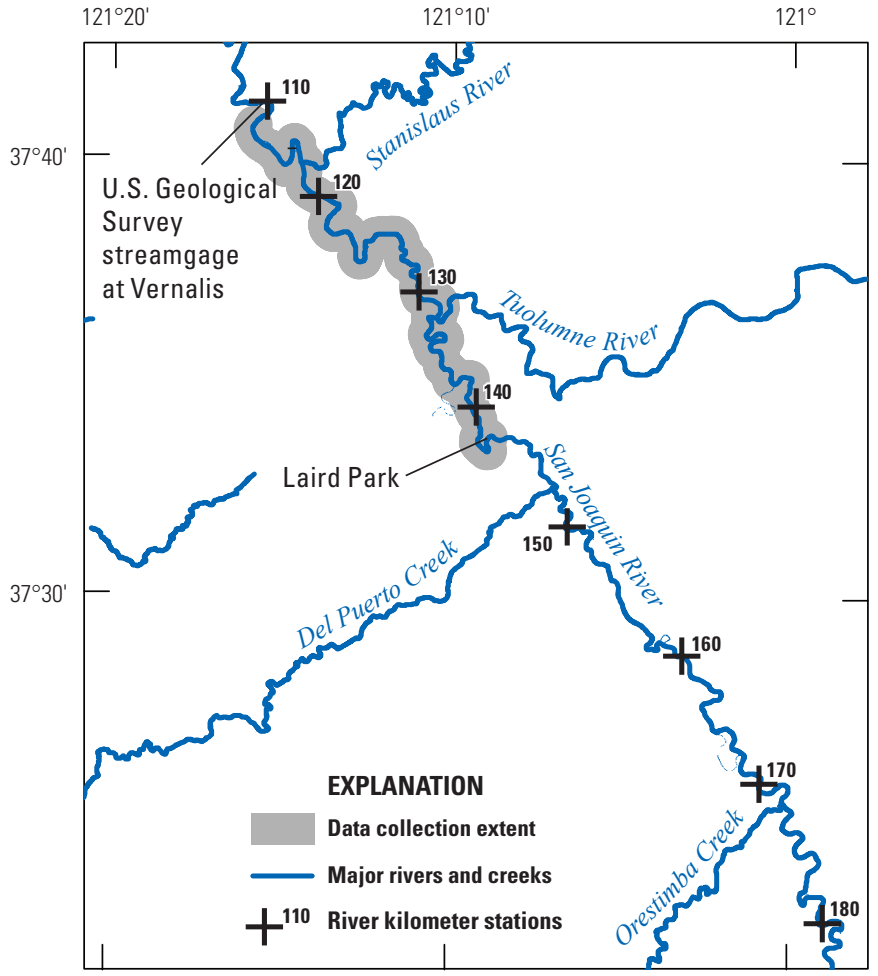

\section{2013}

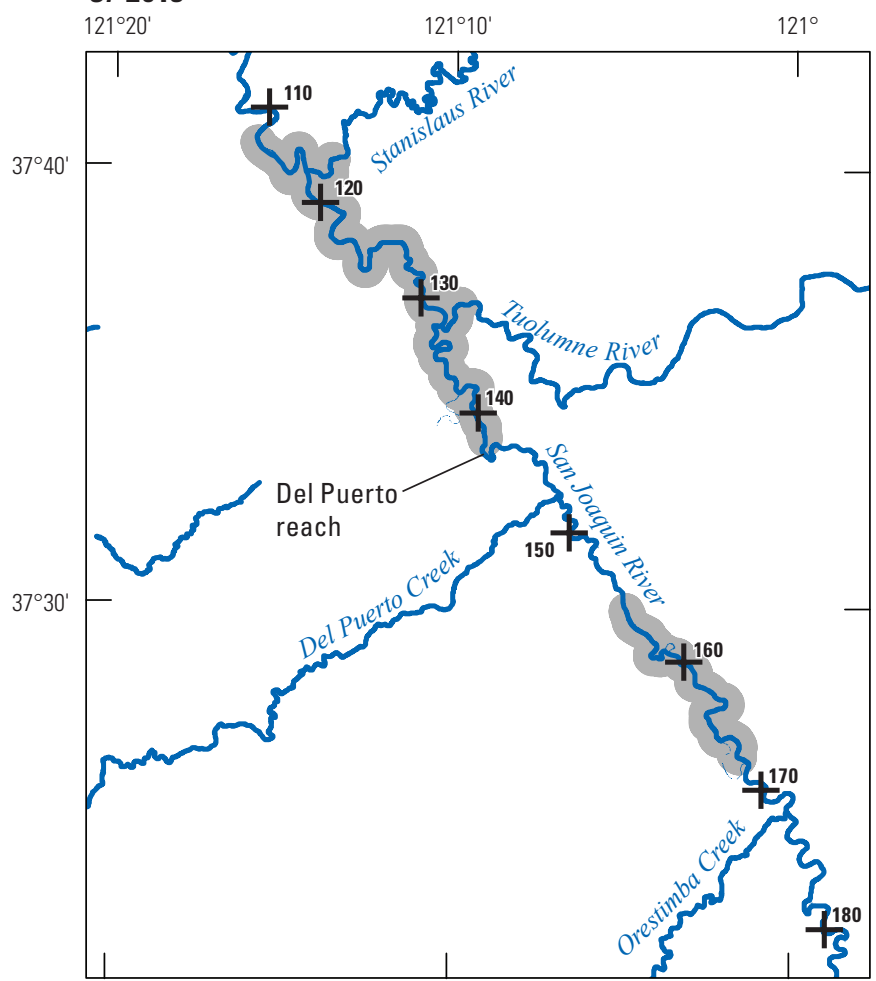

B. 2012

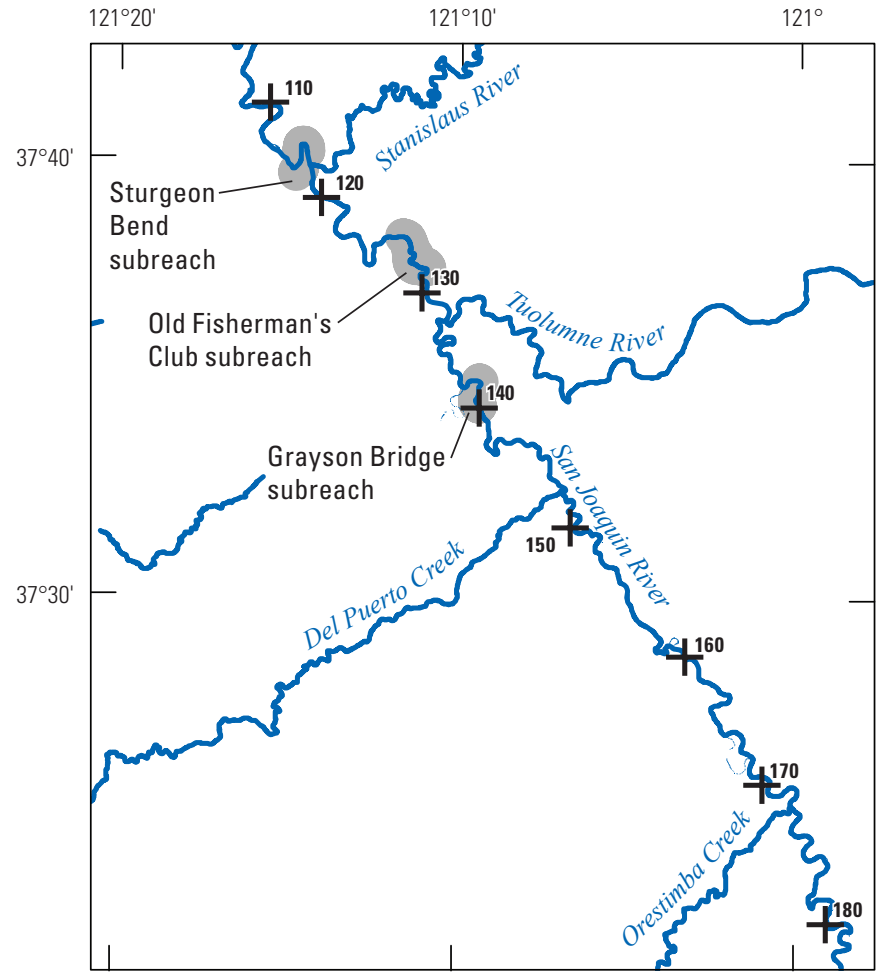

\section{2014}

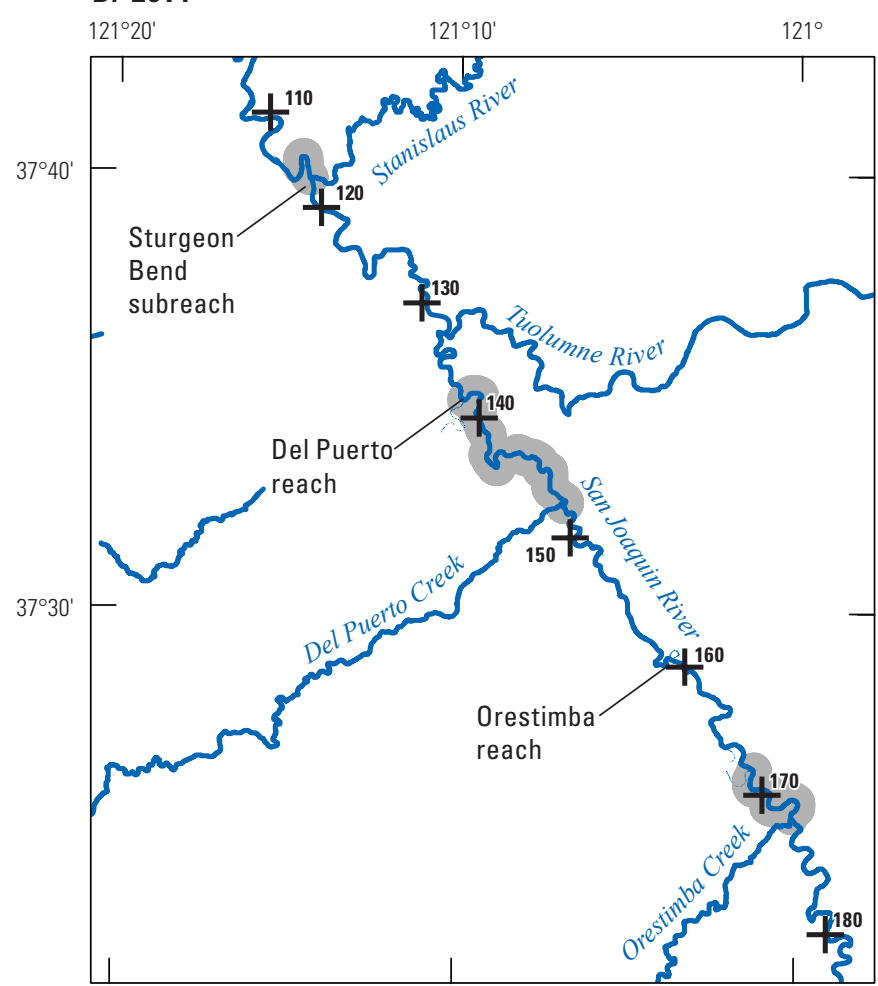

Base modified from U.S. Geological Survey and other Federal and State digital data, various scales; Albers Equal Area Conic projection, standard parallels are $29^{\circ} 30^{\prime \prime}$ and $45^{\circ} 30^{\prime \prime}$; North American Datum of 1983

$\begin{array}{lllllll}0 & & 3 & & 6 & 9 & 12 \text { MLLES } \\ \vdots & 1 & 1 & & 1 & 1 & 1 \\ 0 & 3 & 6 & 9 & 12 \text { KILOMETERS }\end{array}$

Figure 10. Locations where water depth and velocity data were collected, by year, in the lower San Joaquin River, California, 2011-14: $A, 2011 ; B, 2012 ; C, 2013 ;$ and $D, 2014$. 


\section{Bathymetry Mapping using Multibeam Sonar, 2011}

The multibeam sonar survey was completed in 3 days, July 26-28, 2011, along the reach of the lower San Joaquin River between Laird Park and the USGS streamgaging station 11303500, San Joaquin River near Vernalis. Detailed bathymetric maps, based on 2- by 2-m grid spacing, were created for the reach using HYPACK ${ }^{\circledR}$ hydrographic survey software. This resolution was selected to guide efficient collection of the bathymetric points and to produce maps sufficiently detailed to capture the variable topography of the river bed. The only year that had flows sufficiently high to justify using multibeam sonar was 2011; flows in subsequent years were too low for a swath-mapping technique like multibeam sonar to be more efficient than ADCP mapping.

\section{Bed-Material Mapping using Acoustic Backscatter in 2012 and Side-Scan Sonar in 2013}

In 2012, the ADCP backscatter data were analyzed using the methods described by Shields (2010) and compared to bed-material samples. An ADCP operates by transmitting high-frequency acoustic pulses in four directions, and then it records the time and intensity of the reflection of those pulses. The instrument uses the travel time and the frequency shift to compute water velocity, but it also stores details of the amplitude of the return energy (backscatter intensity). Harder, denser bed material, such as gravels, cobbles, bedrock, and consolidated clay (hardpan), can reflect more of the incident acoustic energy than do softer sediments, such as unconsolidated clay, and porous sediments, such as sand, that absorb the energy. The correlation between ADCP acoustic backscatter intensity at the bed and measured particle size was poor (possibly reflecting the coarse resolution of the backscatter intensity from vertical averaging over $0.5-1.0-\mathrm{m}$ cells), however, and was not explored further.

In 2013, two methods were evaluated to identify sediment type using side-scan sonar data. A side-scan sonar is similar in some aspects to the ADCP, except instead of measuring velocity, it uses a wide-angle beam to record a swath of high-resolution backscatter intensity. The highresolution backscatter-intensity data are stored as an image slice, where the digital number of the image pixel represents the relative intensity of the backscatter. These image slices can be post-processed to correct for boat position and heading and then mosaicked to form a map.

The first method used to analyze the side-imaging data was to mosaic the images and view them manually in an attempt to identify bed composition (Kaeser and others,
2012). Two commercially available software programs were compared to evaluate their ability to post-process the raw data files: Dr. Depth (Johnson Outdoors Marine Electronics, Inc.) and Sonar TRX-SI-Pro (Leraand Engineering, Inc.). Both programs were able to mosaic the data, to correct for boat position and heading, and to provide output images of the downward-looking beam and side-looking beams (figs. 11, 12).

The second method tested was to process the data from the downward-looking beam to determine hardness on the basis of the intensity of the acoustic backscatter. The Dr. Depth program was capable of providing an output of "hardness," although no explanation of the calculation for hardness was provided in the documentation. This method was used previously by others to map the bed material in the James River, Virginia (Austin, 2012). In theory, areas with high backscatter intensity contain gravel, cobble, or bedrock, whereas areas with low backscatter contain sand, silt, and clay.

Areas that were identified as likely to have sand, silt, or clay on the basis of side-scan imagery and also had low backscatter intensity were thought to have sand or finer bed material. This fine bed material made up the majority of the survey areas and also reflected that reported by previous literature (Hall, 1886; Mussetter Engineering, Inc., and others, 2000). Areas that had medium or high backscatter intensity, or where the bed-material type could not be easily identified from the side-scan imagery, were thought to potentially contain coarse bed material, such as gravel or cobble. There were not many of these areas, so the bed material at all such sites was sampled in the field. The areas with high backscatter intensity were associated with gravel; cobble rip-rap; hardpan clay; or, occasionally, sand in shallow (less than $0.5 \mathrm{~m}$ ) water. Because the San Joaquin River is predominately a sand-bedded river and a primary interest of this study was to identify the few areas with gravel or cobble bed material, the combination of the two side-scan methods worked well to target sampling in locations with coarser bed materials.

\section{Tributary Longitudinal Elevation and Slope Profiles}

Channel gradient (or slope) in a river can provide some indication of the forces, such as shear stress at the riverbed, available to transport sediment relative to the size of that sediment. River reaches that have steep slopes (such as in mountains) tend to have higher bed shear stresses and transport a wide range of sediment sizes (boulders to silt), whereas river reaches with low slopes (such as on a valley floor) tend to have lower stresses and can only transport finer sediment (such as sand and silt). 


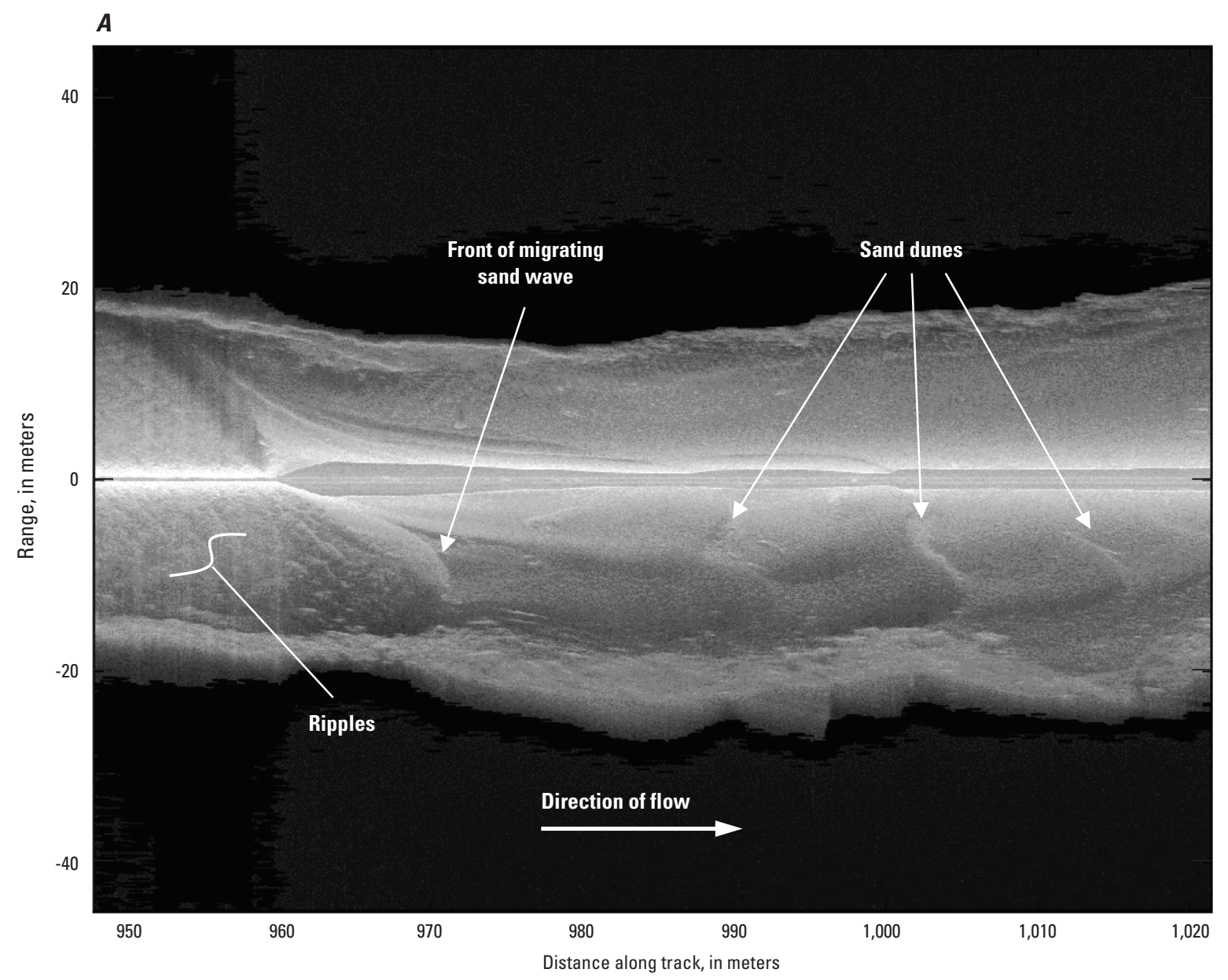

B

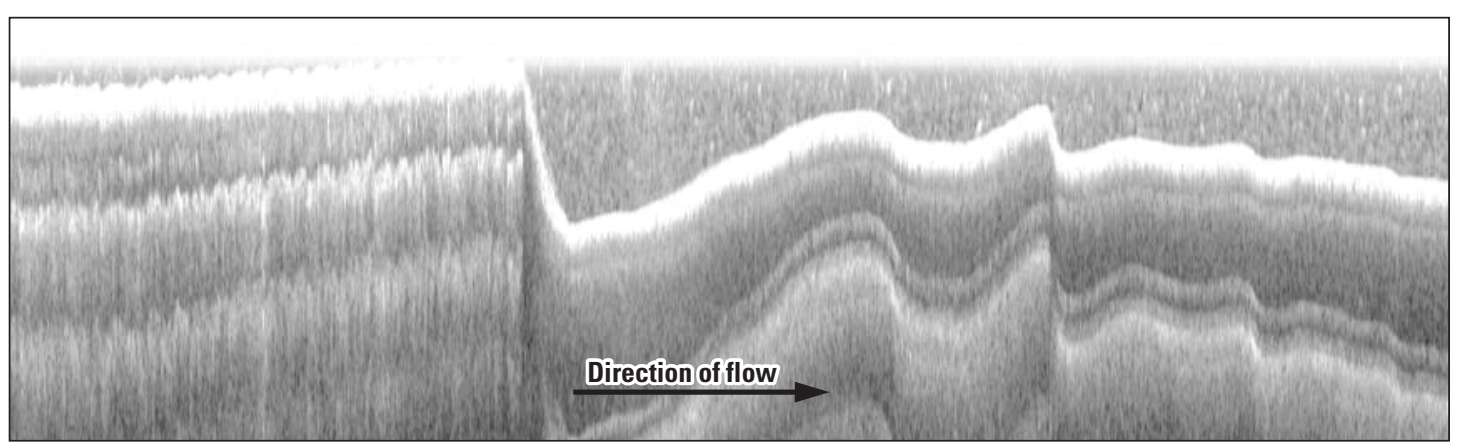

Figure 11. Examples of side-scan sonar from a sand-bedded section in the Grayson Bridge subreach of the lower San Joaquin River, California, April 23, 2013: $A$, plan view; and $B$, profile view showing small ripples translating up the stoss slope on an advancing sediment wave (left) and large migrating sand dunes (right). 


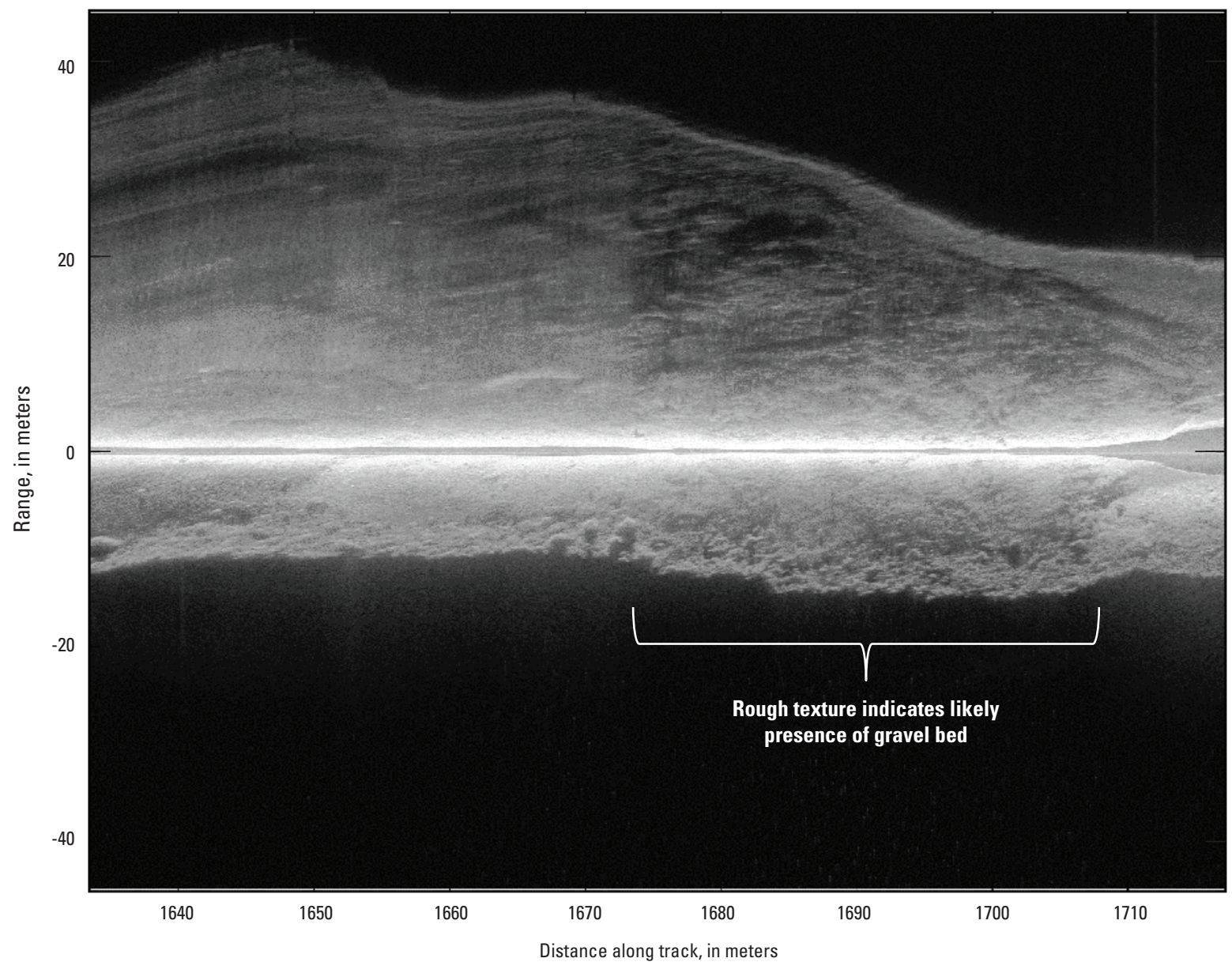

Figure 12. Plan view of side-scan sonar of a gravel-bedded section in the Grayson Bridge subreach of the lower San Joaquin River, California, April 23, 2013. The rough texture of the bed indicates likely presence of gravel, which was confirmed by collection of bedmaterial samples in this area.

We created longitudinal elevation profiles of the San Joaquin River, the three major east-side tributary rivers (Stanislaus, Tuolumne, and Merced), and two west-side tributary creeks (Del Puerto and Orestimba) using elevation data from the National Elevation Dataset (U.S. Geological Survey, 2015a), which had a 30-m grid resolution, and centerlines from the National Hydrography Dataset (U.S. Geological Survey, 2015b). Although water-surface elevation was surveyed in some areas using the GPS-RTN, this dataset was not sufficient to generate maps for the entire study area in the lower San Joaquin River or for the tributary rivers. For each river or creek, we divided the river centerline into stations spaced at $100-\mathrm{m}$ intervals. The elevation at each point was assigned by sampling the NED-derived elevation model using spatial analysis tools in ArcMap; each centerline station also was indexed to the distance upstream from the tributary mouth. We then derived channel gradient using the change in elevation between each 100-m station and smoothed the channel-gradient profile using a $10-\mathrm{km}$ averaging window. The 10-km averaging window helps smooth over uncertainties in elevation that result from the digital elevation model of the centerline not always reflecting the true, within-bank, watersurface elevation, but instead providing a sense of the general gradient of the river. This provided an appropriate dataset for comparing reach-averaged gradients among the reaches.

\section{Bed-Material Sampling, 2012-14}

Bed material was sampled using a US BM-54 and US BMH-60, which are cable- and handline-suspended versions, respectively, of a rotary-scoop bed-material sampler, following standard USGS protocols for use of these samplers (Subcommittee on Sedimentation, 1958; Edwards and Glysson, 1999; Davis, 2005) from a motorized boat. These types of samplers are designed to collect material from the top $5 \mathrm{~cm}$ of the bed. Samples were collected during 3 years of the study (2012-14), but were not collected during the first year of the study (2011). Approximate locations of bed-material samples collected in each water year are shown in figure 13. 
A. 2011

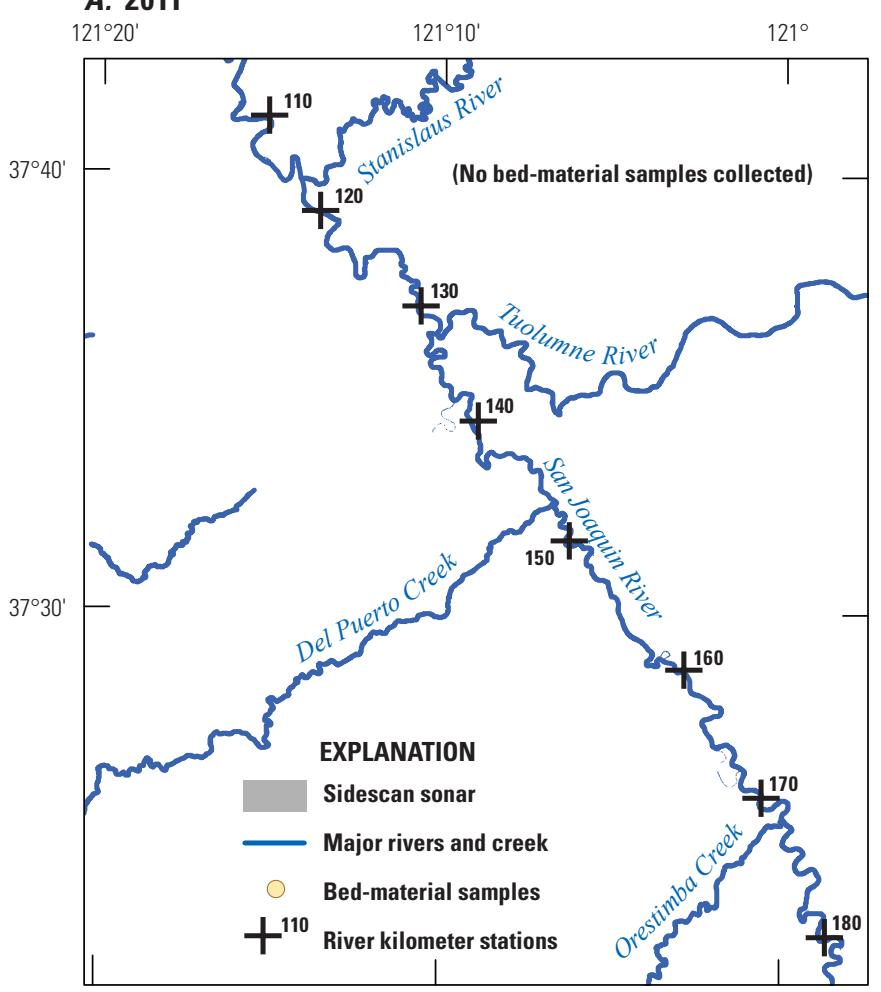

C. 2013

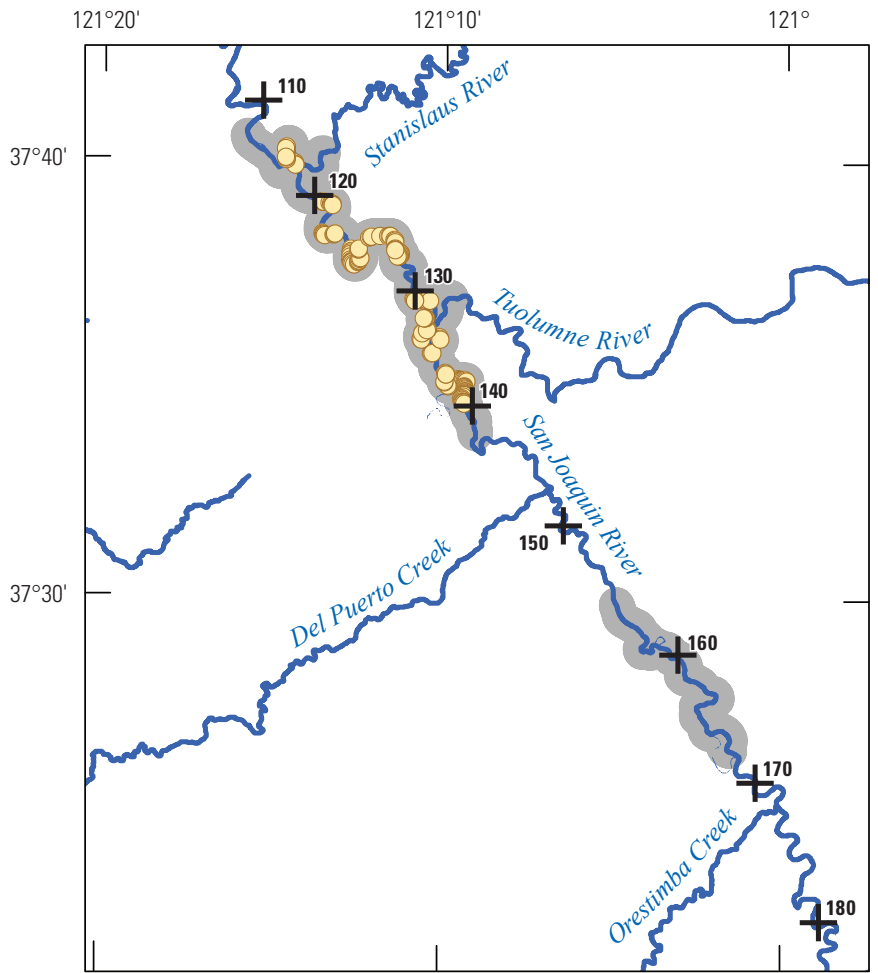

B. 2012

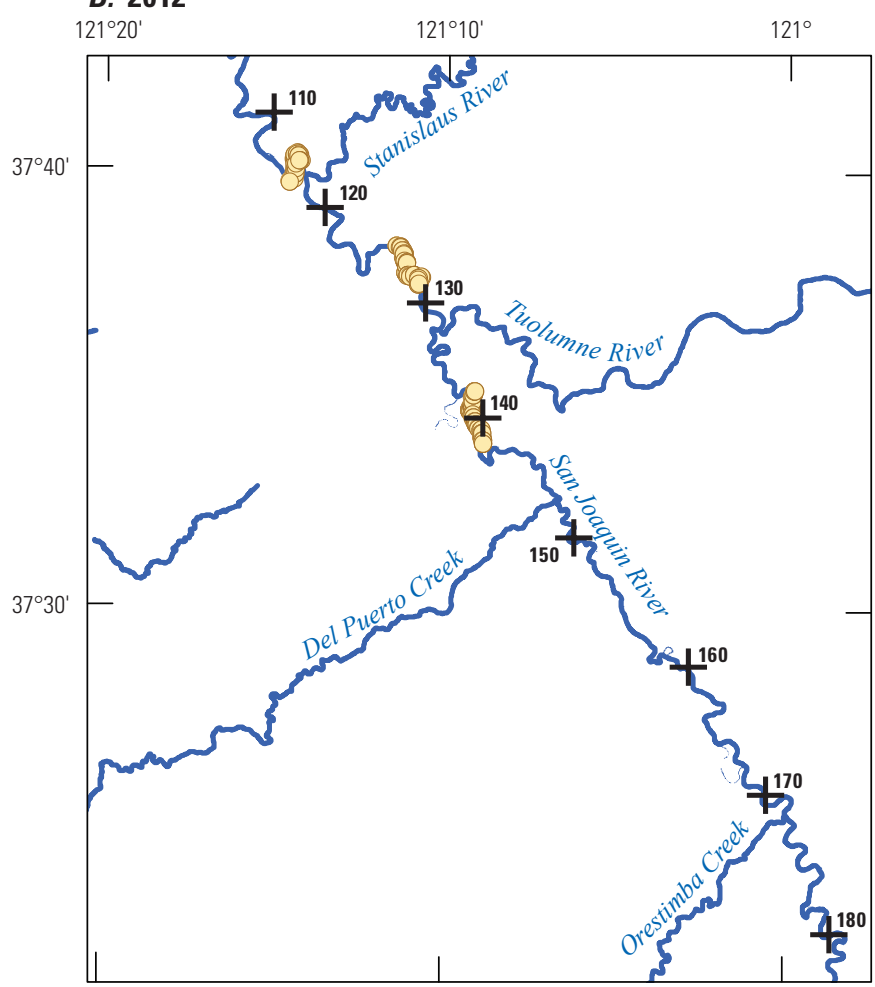

\section{2014}

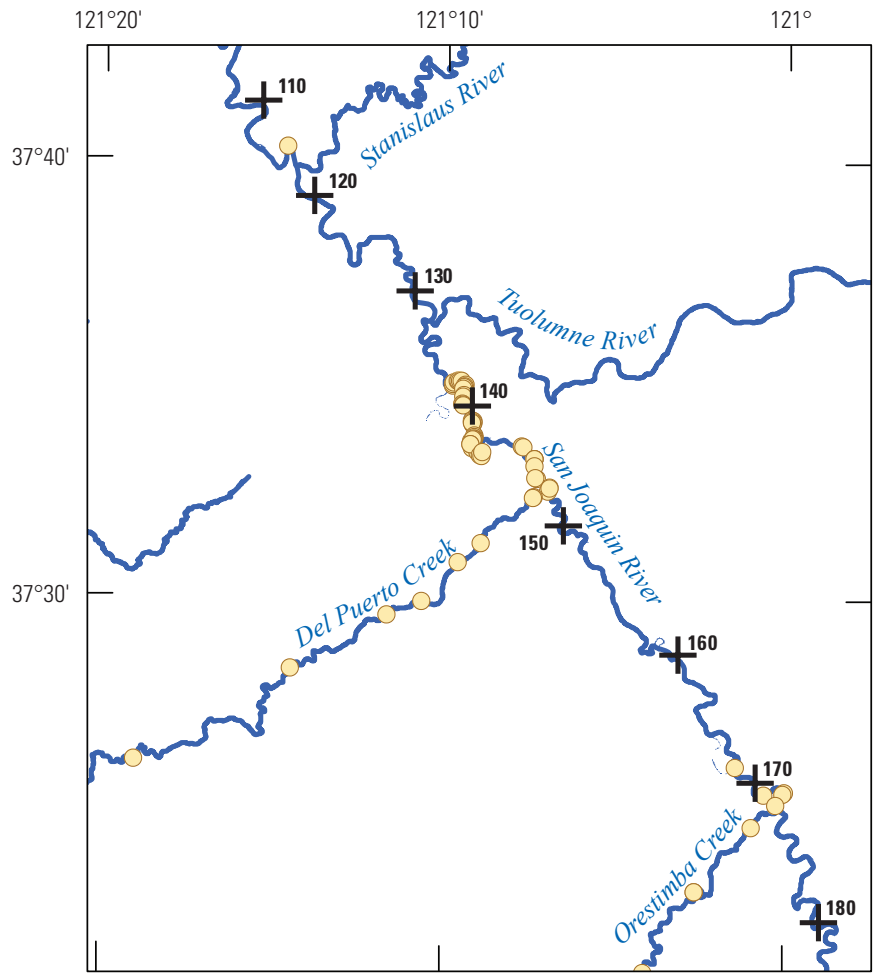

Base modified from U.S. Geological Survey and other Federal and State digital data, various scales; Albers Equal Area Conic projection, standard parallels are $29^{\circ} 30^{\prime \prime}$ and $45^{\circ} 30^{\prime \prime}$; North American Datum of 1983

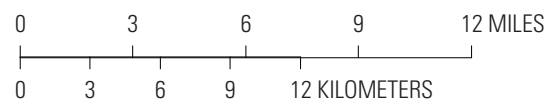

Figure 13. Sites where bed-material samples were collected in the lower San Joaquin River, Del Puerto Creek, and Orestimba Creek, California: $A, 2011 ; B, 2012 ; C, 2013$ (including the linear extent of 2013 side-scan sonar data collection); and $D, 2014$. 
The locations of sample collection were recorded using the boat's on-board GPS navigation system, a mobile phone with a GPS software application, or by cross-referencing sample time with the GPS coordinates stored in the ADCP. The accuracy of the boat's on-board GPS was about plus or minus $2.5 \mathrm{~m}$ (Johnson Outdoors Marine Electronics Inc., 2014), and the mobile phone GPS was about plus or minus $8 \mathrm{~m}$ (Zandbergen, 2009). Additional information about sampling (location in channel, date and time, and depth of sample) was also recorded routinely.

In 2012, transects were established at the three subreaches to collect bed-material samples and ADCP measurements. At each transect, the channel was divided into five equal-width sections, and a bed-material sample was collected at the center of each section.

In 2013, the sampling protocol was modified to increase spatial coverage. First, longitudinal profiles of the streambed were collected as side-scan sonar images. These data were processed and reviewed to identify "areas of interest" using backscatter-intensity data and images (the methods are discussed in the previous section). "Areas of interest," for the purpose of this study, were areas that potentially had coarse bed material, as indicated either by high acoustic backscatter intensity or the side-scan imagery showing rough texture or heterogeneous surfaces (for example, fig. 12) that could potentially signal the presence of coarse bed material. At areas of interest, one or more bed-material samples were collected in the center of the channel. If an area of mostly coarse bed material was found, additional samples were collected upstream and downstream to identify the longitudinal extent of the coarse bed material. Based on the results from the 2012 bed-material transect samples, the sediment type did not vary much across the streambed laterally. Therefore, a single bed-material sample collected from the center of the channel was deemed sufficient to represent the bed material at that longitudinal station. On occasion, a sampler came up empty or only contained a small amount of clay material. This was assumed to indicate the sampler hit hardpan clay that the scoop could not penetrate.

In addition to the bed-material samples collected in the main channel, samples were collected from streambanks, gravel bars, and the west-side tributary creeks in 2014 to try to determine the likely source of the coarse bed material (gravel and cobble) in the lower San Joaquin River. Lowstreamflow conditions in 2014 limited the ability to collect bed-material samples using traditional sampling techniques. In shallow areas (less than $1.2 \mathrm{~m}$ ), a metal pole was used to prod the streambed to determine if the bed was composed of soft material (sand and silt) or hard material (gravels and cobbles). If gravel or cobble was detected using the prodding method in a wadable area, then a grab sample was collected; if the area was too deep, the location was recorded, but no sample was collected.

\section{Bed-Material Sample Preparation and Particle- Size Analysis}

Bed-material samples were dried in an oven at 105 degrees Celsius. After samples were dried, clumps of sediment were disaggregated using a mortar and pestle. Particle-size distribution of the sample material was then determined using a combination of sieving and direct measurement.

Sieving of sediment particles smaller than $2 \mathrm{~mm}$ followed standard sieving methods (Guy, 1969). For the sieved portions, the fraction of particles finer than $0.063 \mathrm{~mm}, 0.125 \mathrm{~mm}$, $0.5 \mathrm{~mm}, 1 \mathrm{~mm}$, and $2 \mathrm{~mm}$ were weighed and recorded. If a sample contained particles larger than $2 \mathrm{~mm}$, those particles were sorted by size manually using an SAH-97 hand-held particle-size analyzer (Potyondy and Bunte, 2002). The total weight of each size class was recorded and then used with the sieve data to determine the particle-size distribution.

The median, tenth-percentile, and ninetieth-percentile grain sizes were calculated using linear interpolation between logarithmically transformed particle-size classes. The percentages of fine sediment, sand, gravel, and cobble in each sample were also calculated. In this report, fine sediment is smaller than $0.063 \mathrm{~mm}$; sand is from 0.063 to less than $2 \mathrm{~mm}$; gravel is from 2 to less than $64 \mathrm{~mm}$; and cobble is from 64 to less than $256 \mathrm{~mm}$ (table 4).

Table 4. Description and size range of sediment particles in particle-size categories used in this report.

[mm, millimeter; <, less than; >, greater than]

\begin{tabular}{cc}
\hline Particle-size category & Size range $(\mathbf{m m})$ \\
\hline Fine (silt/clay) & $<0.063$ \\
Sand & $0.063-2$ \\
Gravel & $>2-64$ \\
Cobble & $>64-256$ \\
\hline
\end{tabular}




\section{Summary of Channel Characteristics, Stream Slope, and Bed Aggradation in the Lower San Joaquin River}

The following section provides a summary of the results from this study related to (1) water depth and velocity, (2) bed material, (3) stream slope, and (4) aggradation. Water depth and velocity measurements provided information about general conditions in the lower San Joaquin River during these years, particularly the identification of deep scour holes and high-velocity areas. The lower San Joaquin River was nearly all sand-bedded, except for a series of gravel-bedded areas downstream from the Del Puerto Creek confluence and a small patch downstream from the Orestimba Creek confluence. The stream slope of the lower San Joaquin River and most of its tributaries is low, except in Del Puerto and Orestimba Creeks. Bed aggradation was observed in areas through repeated measurements, such as in the Sturgeon Bend subreach.

\section{Depth and Velocity}

Ranges of the approximate channel depth and depthaveraged velocity for the entire study area between 2011 and 2014 are shown in figures 14 and 15. Most of the depth data presented here were collected using an ADCP; however, some depth data were collected using an Odem multibeam in 2011. The depth data from the multibeam and ADCP were combined for this section of the report. Detailed depth and velocity data are available online (Marineau and others, 2017).

\section{Water Year 2011: Wet}

The California Department of Water Resources (2015) classified 2011 as a wet water year. In the spring of 2011, a combination of heavy rainfall and rapid snowmelt caused streamflows in the lower San Joaquin River to increase over a few months, peaking at 875 cubic meters per second $\left(\mathrm{m}^{3} / \mathrm{s}\right)$ on April 2, 2011 (recorded at San Joaquin River near Vernalis, $C A$, Station 11303500). Field data were collected July 19-21, 2011, when the streamflow was much lower (but still relatively high for the river), ranging from 196 to $256 \mathrm{~m}^{3} / \mathrm{s}$.

Because the highest flows during the study were in 2011, water depth and velocity in that year were higher than during all subsequent 3 years of data collection. The maximum depth recorded was $14.0 \mathrm{~m}$, at Sturgeon Bend. Several deep pools were found in the river that year. In the $30-\mathrm{km}$ reach (Rkm 111.5-141.8) surveyed in 2011, 21 pools deeper than $6 \mathrm{~m}$ were recorded. Of those, five were deeper than $9 \mathrm{~m}$ (not including Sturgeon Bend). Most of these deep areas were associated with sharp river bends, which can have complex and dynamic flow patterns, and were typically about one channel width long. On average, there was one deep pool (greater than $6 \mathrm{~m}$ ) for every $1.4 \mathrm{~km}$ of channel surveyed.

During the 2011 data-collection period, depth-averaged velocity exceeded $0.5 \mathrm{~m} / \mathrm{s}$ in all river reaches measured, was very often more than $1.0 \mathrm{~m} / \mathrm{s}$, and exceeded $2.0 \mathrm{~m} / \mathrm{s}$ in some areas. A visual inspection was made of the depth relative to velocity by plotting points where depth and velocity data were both available. Based on that plot, there was no apparent correlation between channel depth and depth-averaged velocity.

\section{Water Years 2012-14: Dry and Critical}

Water years 2012 and 2013-14 were dry and critical respectively, based on runoff in the San Joaquin Basin (California Department of Water Resources, 2015). During these years, the peak flow measured at the downstream end of the study area was about 80-90 percent less than it was in 2011 (fig. 8) and was 165, 119, and $87 \mathrm{~m}^{3} / \mathrm{s}$ for 2012, 2013, and 2014, respectively (recorded at USGS streamgage 11303500, San Joaquin River near Vernalis, CA).

In water years 2012-14, depth and velocity were generally less than that measured in 2011. For instance, water depth measured at Sturgeon Bend decreased from $14.0 \mathrm{~m}$ in 2011 to $9.4 \mathrm{~m}$ in $2012,5.8 \mathrm{~m}$ in 2013 , and $3.8 \mathrm{~m}$ in $2014-\mathrm{a}$ total decrease of about $10 \mathrm{~m}$ in 4 years. This decrease in depth was only partially related to the low water stage during those dry years (relative to bed features that have persisted from year to year); it primarily was caused by $8 \mathrm{~m}$ of sediment aggradation during the same period (discussed later in this report).

Depth-averaged streamflow velocity was typically less than $1.0 \mathrm{~m} / \mathrm{s}$ during the dry and critical water years (fig. 15). There were isolated areas where depth-averaged velocity exceeded $1.0 \mathrm{~m} / \mathrm{s}$, particularly downstream from the confluence with the Stanislaus River. The higher velocity in the main stem downstream from this confluence appeared to be primarily due to reservoir releases at New Melones Dam on the Stanislaus River. Streamflow in the lower San Joaquin River upstream from the Stanislaus River confluence was about half of that recorded at the Vernalis gage.

\section{Bed-Material Composition and Sources}

Results of the bed-material size analysis are shown on remotely sensed imagery along with water depth or velocity measurements in figures 16-21. Additional sediment samples were collected from dry stream beds or gravel bars (figs. 22-27). A plot of the 50th (median), 10th, and 90th percentiles of particle size in each sample by river kilometer along the lower San Joaquin River and up Del Puerto and Orestimba Creeks is shown in figure 28. 


\section{A. 2011}

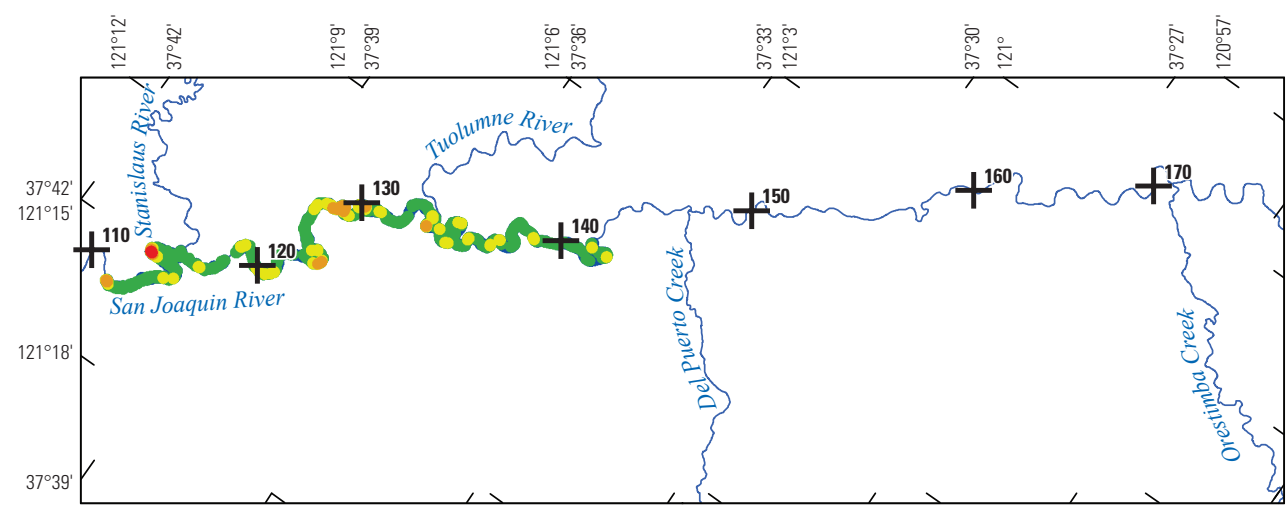

\section{B. 2012}
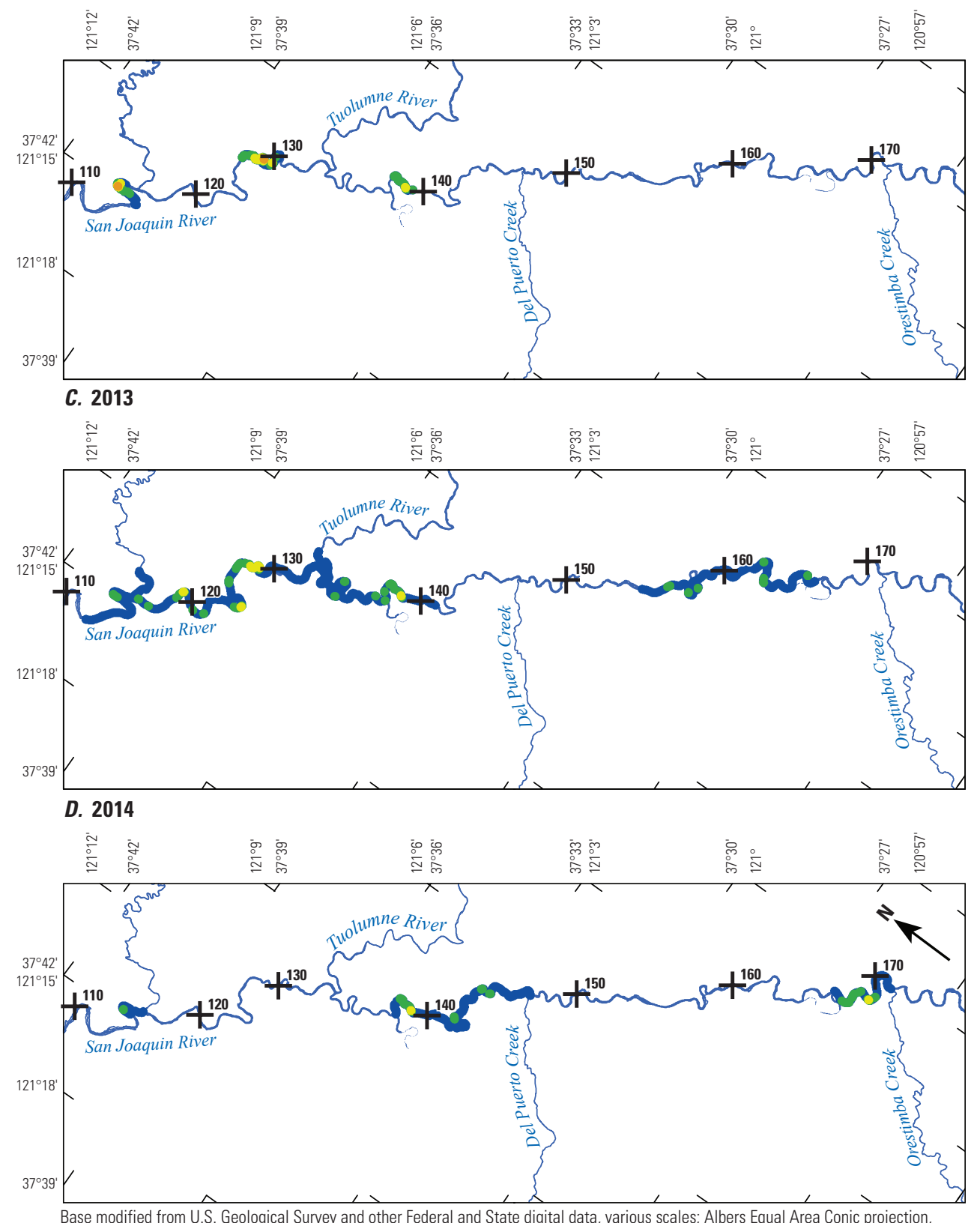

\section{EXPLANATION}

Depth, in meters

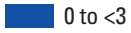

3 to $<6$

6 to $<9$

9 to $<12$

12 to $<15$

— Major rivers and lakes

$+^{110}$ River kilometer stations

$\begin{array}{lllll}0 & 1 & 2 & 3 & 4\end{array}$ MILES

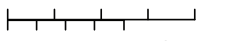

$\begin{array}{lllll}0 & 1 & 2 & 3 & 4 \\ 1 & \text { KILOMETERS }\end{array}$

Base modified from U.S. Geological Survey and other Federal and State digital data, various scales; Albers Equal Area Conic projection,

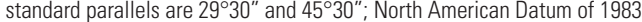

Figure 14. Water depth in the lower San Joaquin River, California: $A, 2011 ; B, 2012 ; C, 2013$; and D, 2014. Symbols for greater depth values are overlain on symbols for lesser values. 
A. 2011
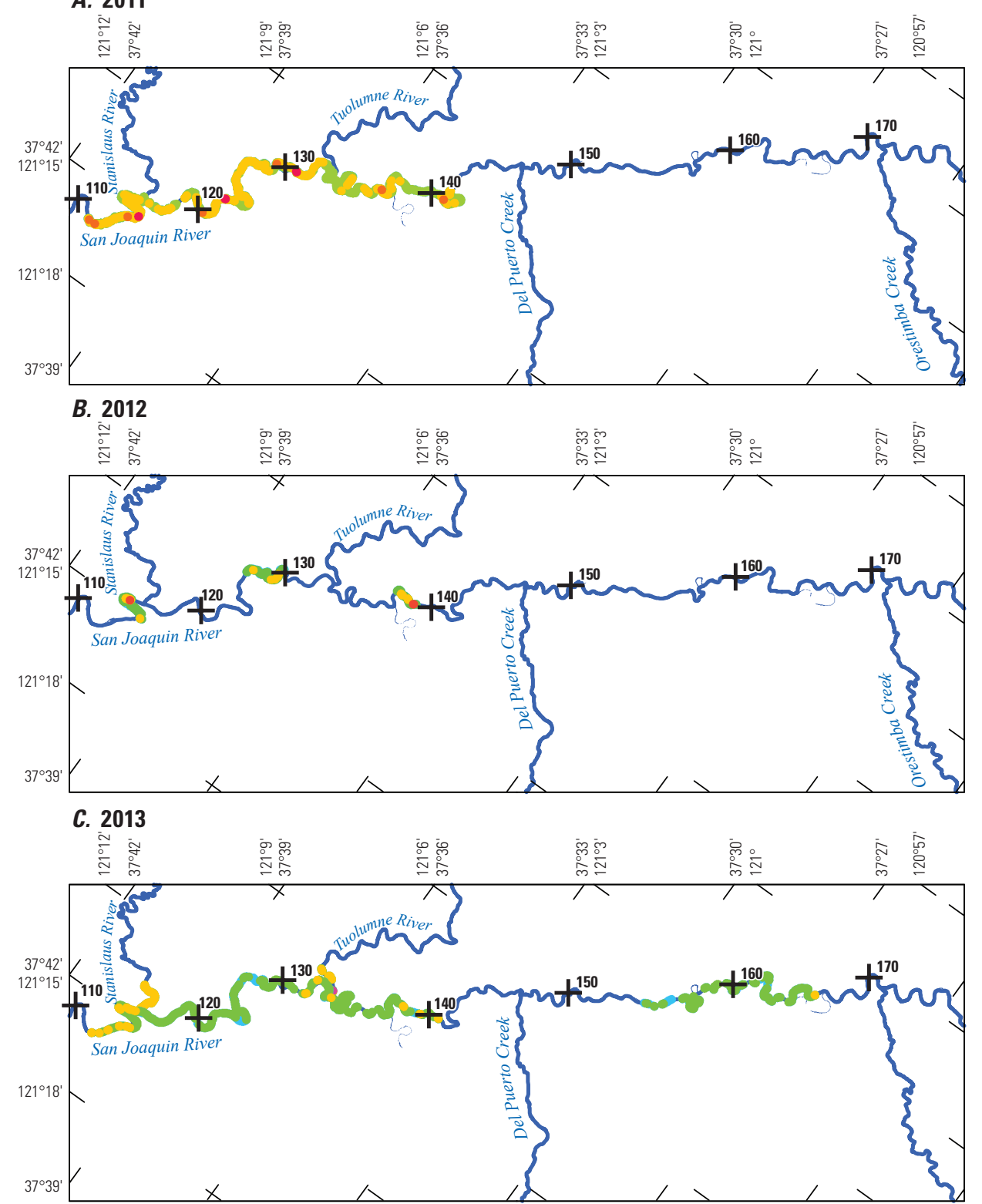

\section{EXPLANATION}

Velocity, in meters per second

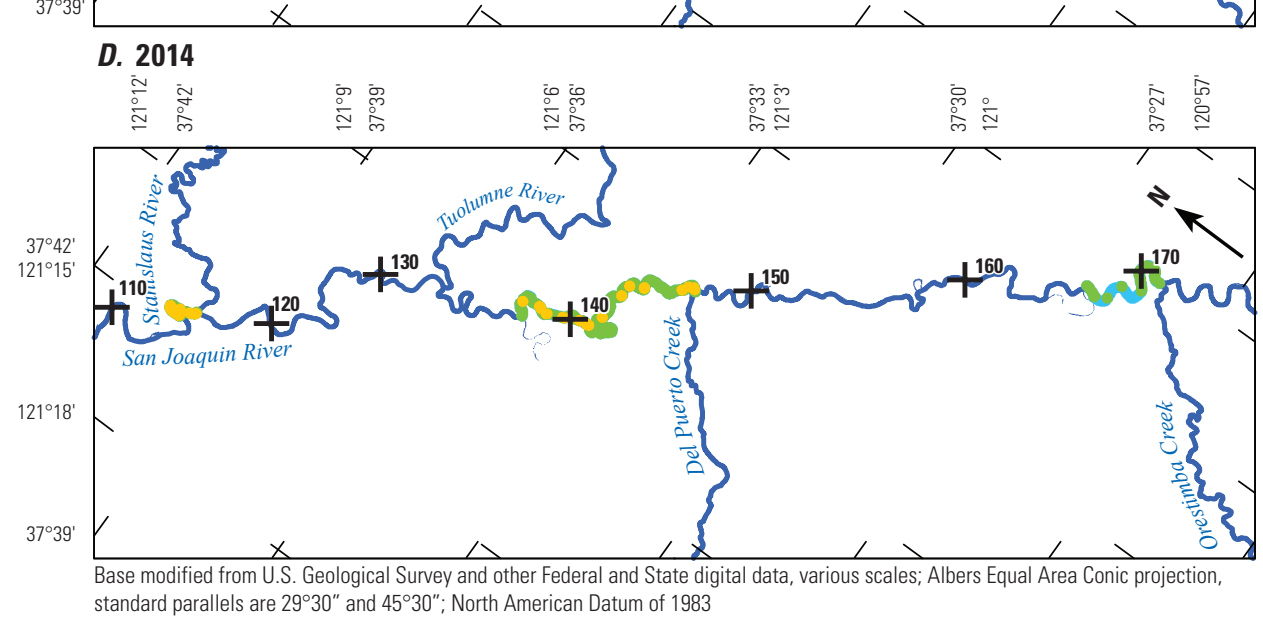

0.5 to $<1$

1 to $<1.5$

1.5 to $<2$

2 to $<2.5$

Major rivers and lakes

$+^{110}$ River kilometer stations

$\begin{array}{lllll}0 & 1 & 2 & 3 & 4\end{array}$ MILES $\begin{array}{llllll}\qquad & & & 1 & 1 \\ 0 & 1 & 2 & 3 & 4 & \text { KILOMETERS }\end{array}$

Figure 15. Depth-averaged velocity in the lower San Joaquin River, California: $A, 2011 ; B, 2012 ; C, 2013$; and D, 2014. Symbols for greater depth-averaged velocity values are overlain on symbols for lesser values. 

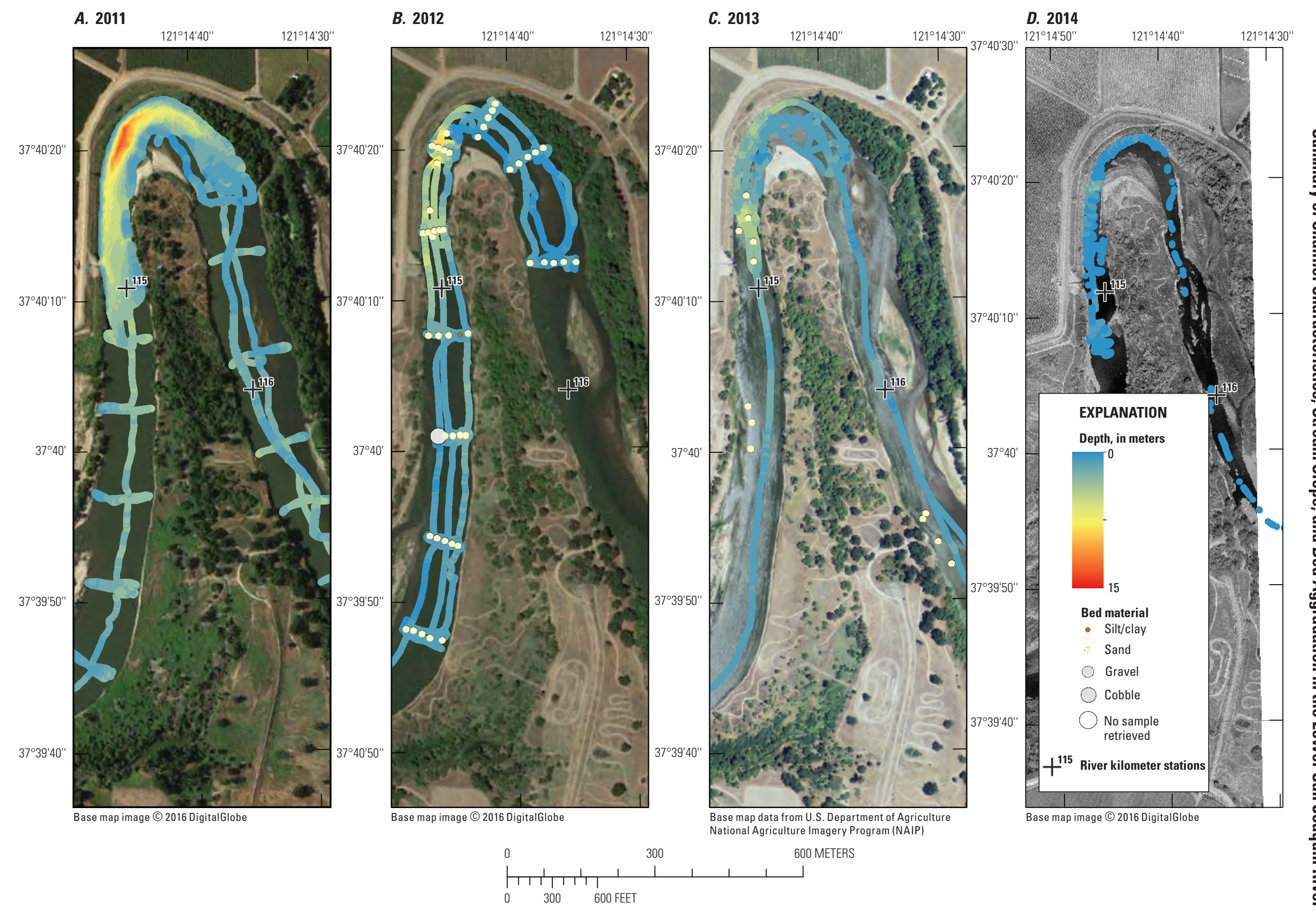

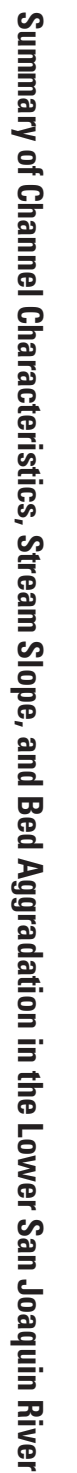

Figure 16. Water depth and bed-material size class in the Sturgeon Bend subreach of the lower San Joaquin River, California (river kilometers 111.9-116.3): $A, 2011 ; B, 2012$; C, 2013; and D, 2014. 

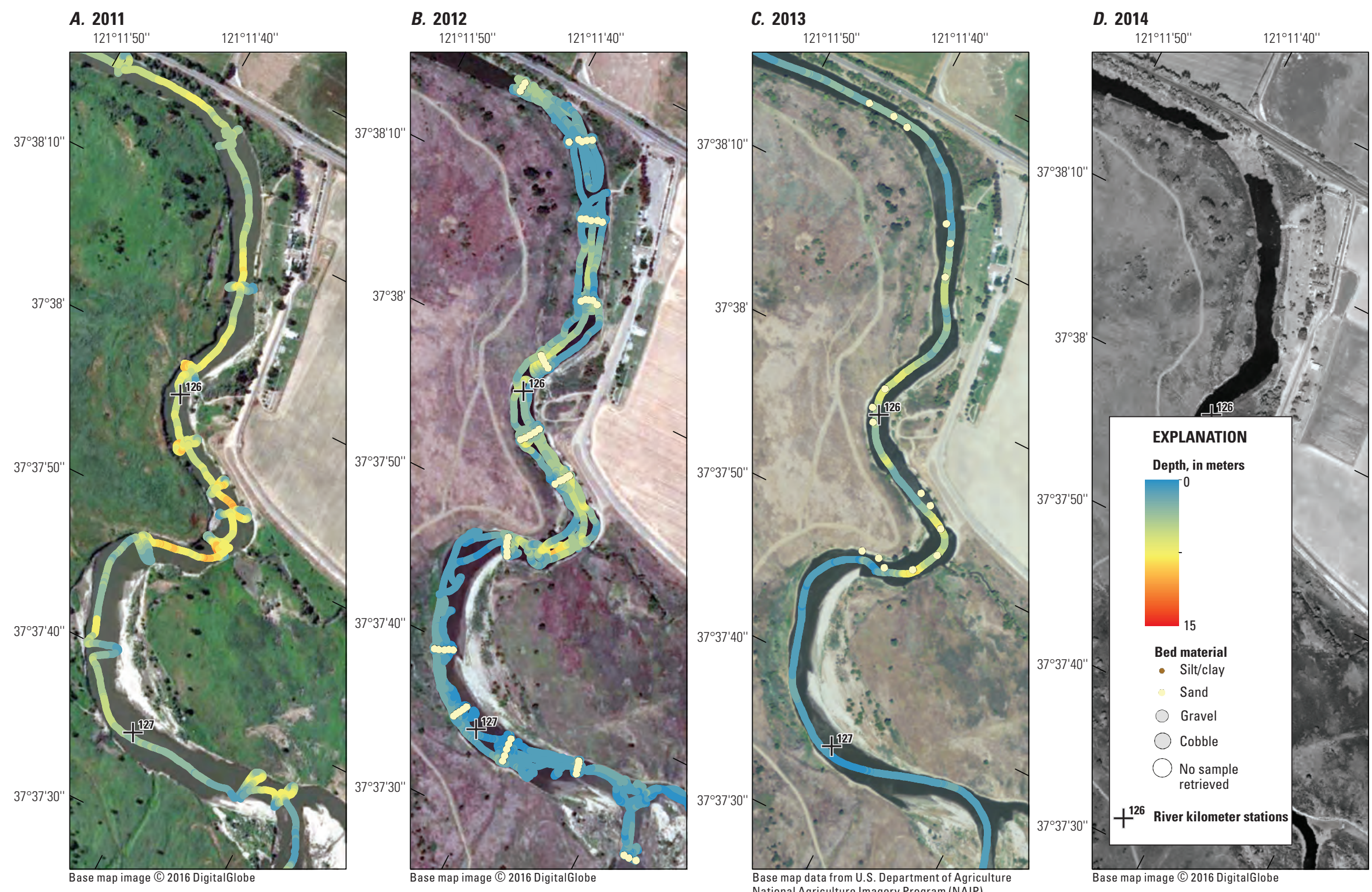

กั

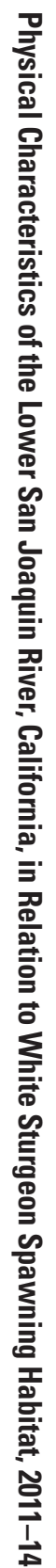

Figure 17. Water depth and bed-material size class in the Old Fisherman's Club subreach of the lower San Joaquin River, California (river kilometers 125.2-127.5): $A, 2011$; $B, 2012 ; C, 2013$; and $D, 2014$. No depth data or bed-material samples were collected in 2014 from this subreach. 

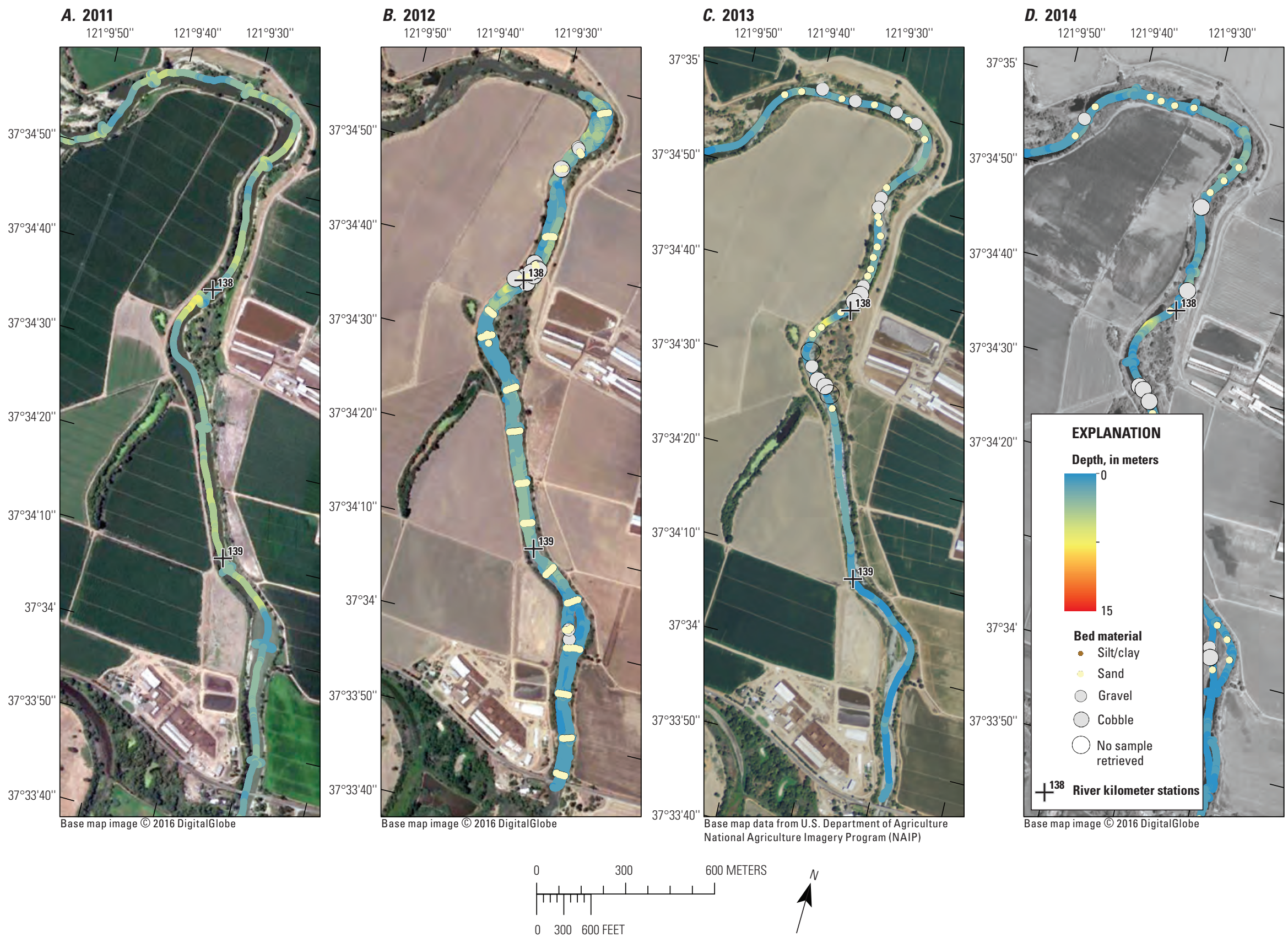

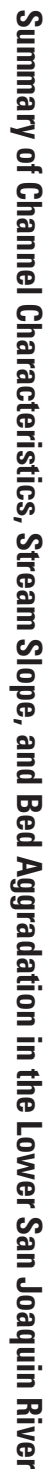

Figure 18. Water depth and bed-material size class in the Grayson Bridge subreach of the lower San Joaquin River, California (river kilometers 137.3-139.9): $A, 2011 ; B, 2012$; $C, 2013$; and $D, 2014$ 

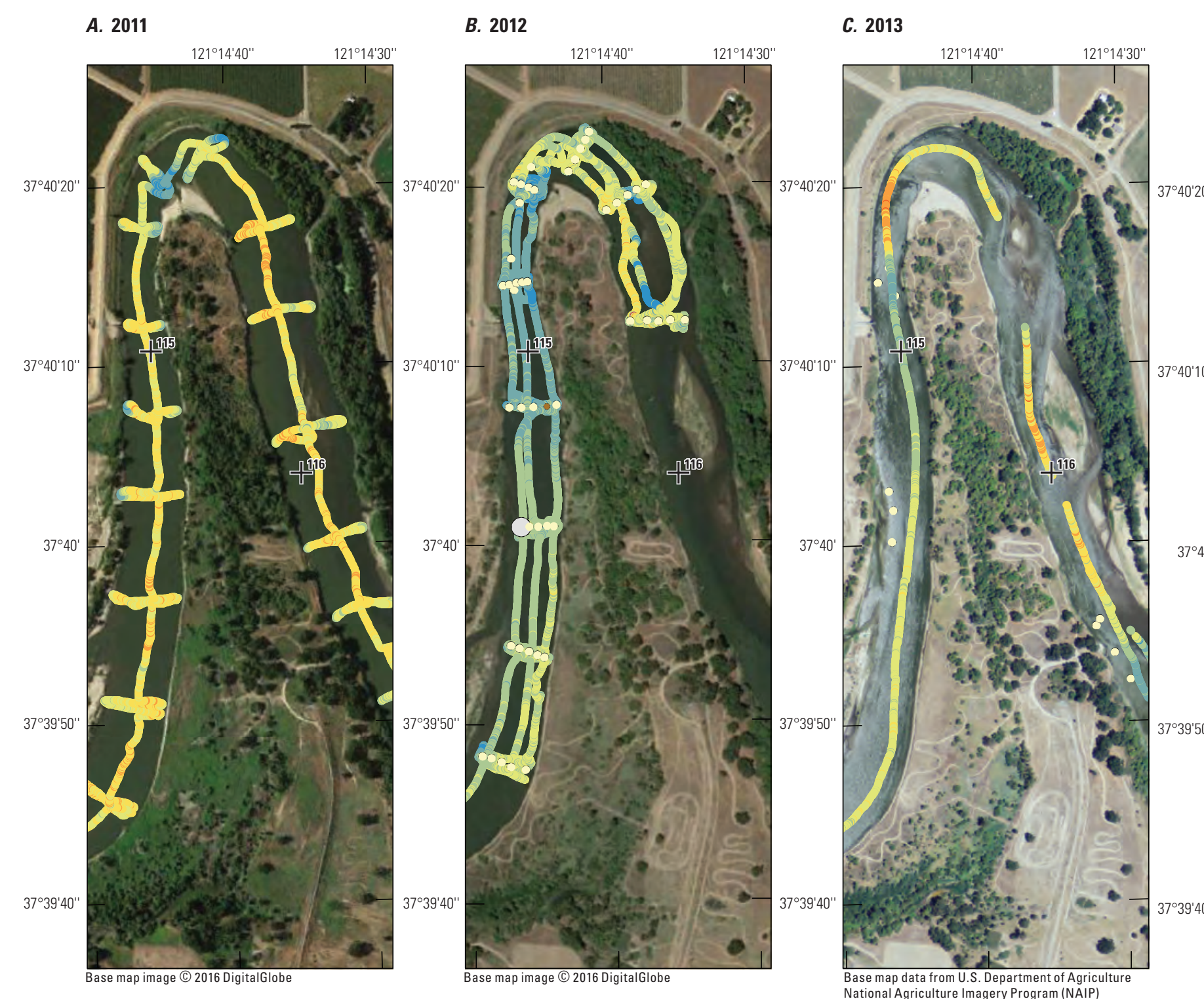

D. 2014

$\tilde{\infty}$
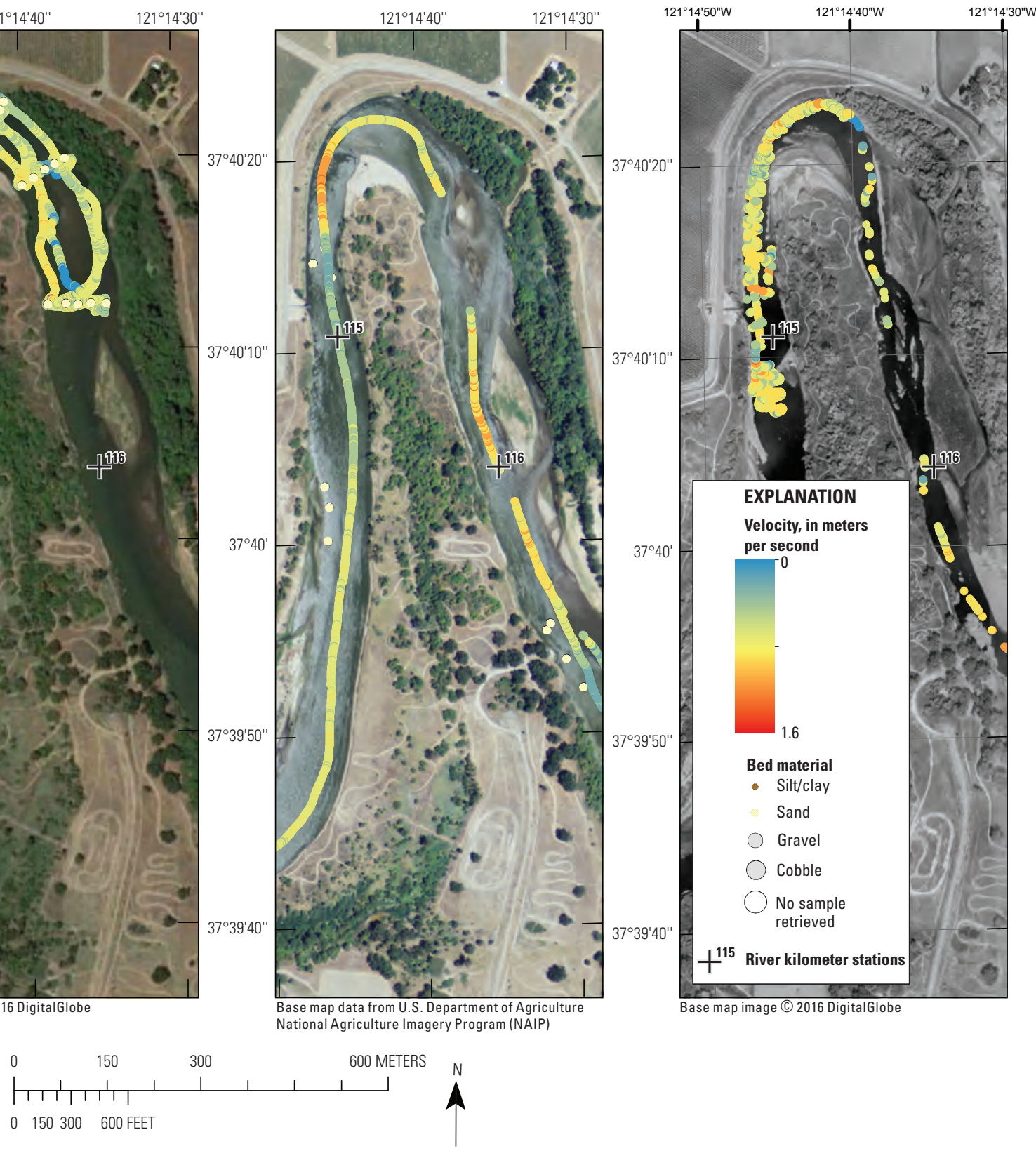

Figure 19. Streamflow depth-averaged velocity and bed-material size class in the Sturgeon Bend subreach of the lower San Joaquin River, California (river kilometers 111.9116.3): $A, 2011 ; B, 2012 ; C, 2013$; and $D, 2014$. 

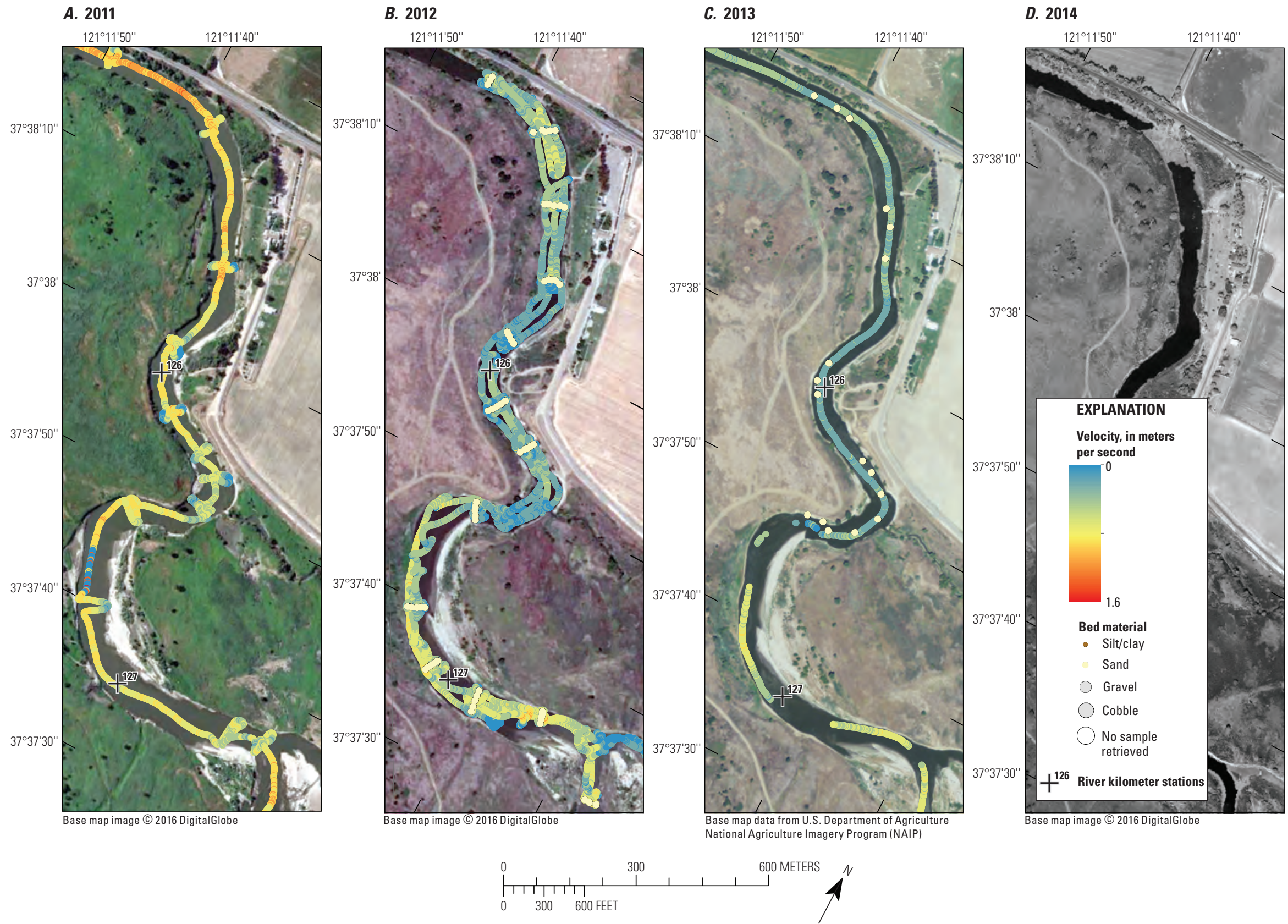

Figure 20. Streamflow depth-averaged velocity and bed-material size class in the Old Fisherman's Club subreach of the lower San Joaquin River, California (river kilometers 125.2-127.5): $A, 2011 ; B, 2012 ; C, 2013$; and $D, 2014$. No depth data or bed-material samples were collected in 2014 from this subreach. 
A. 2011

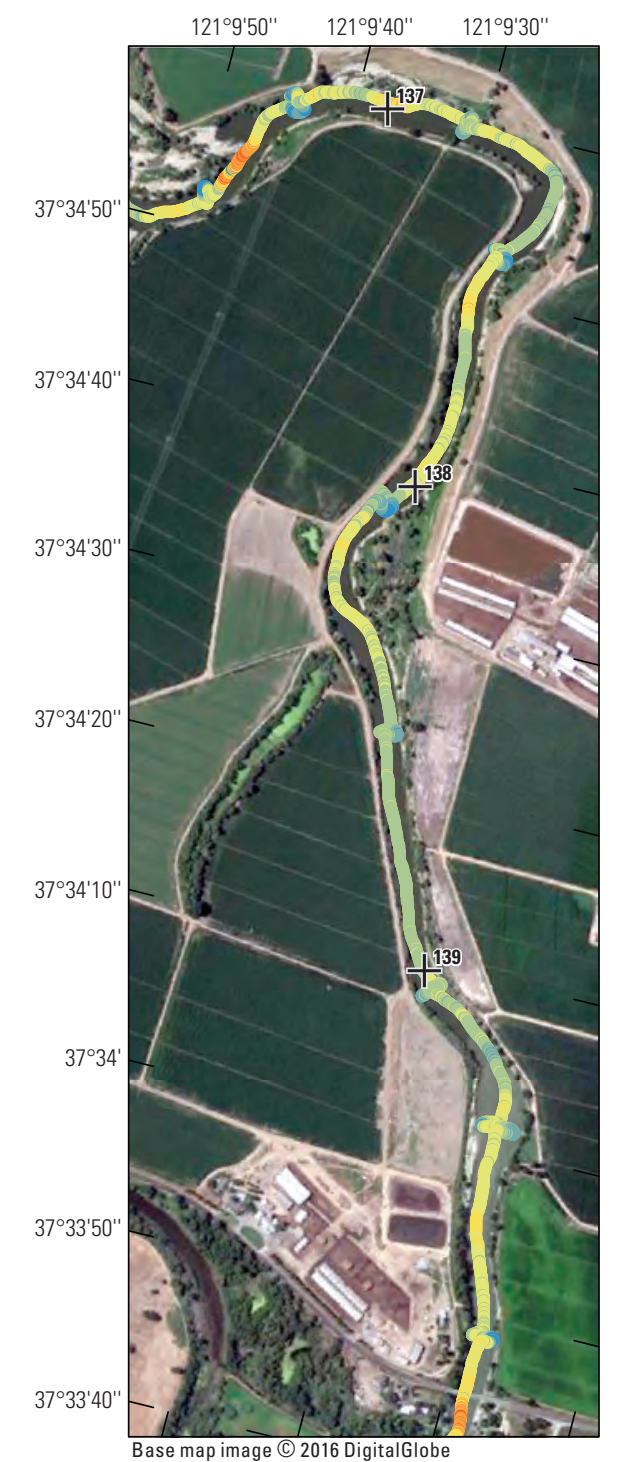

B. 2012

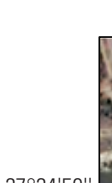

\section{.}
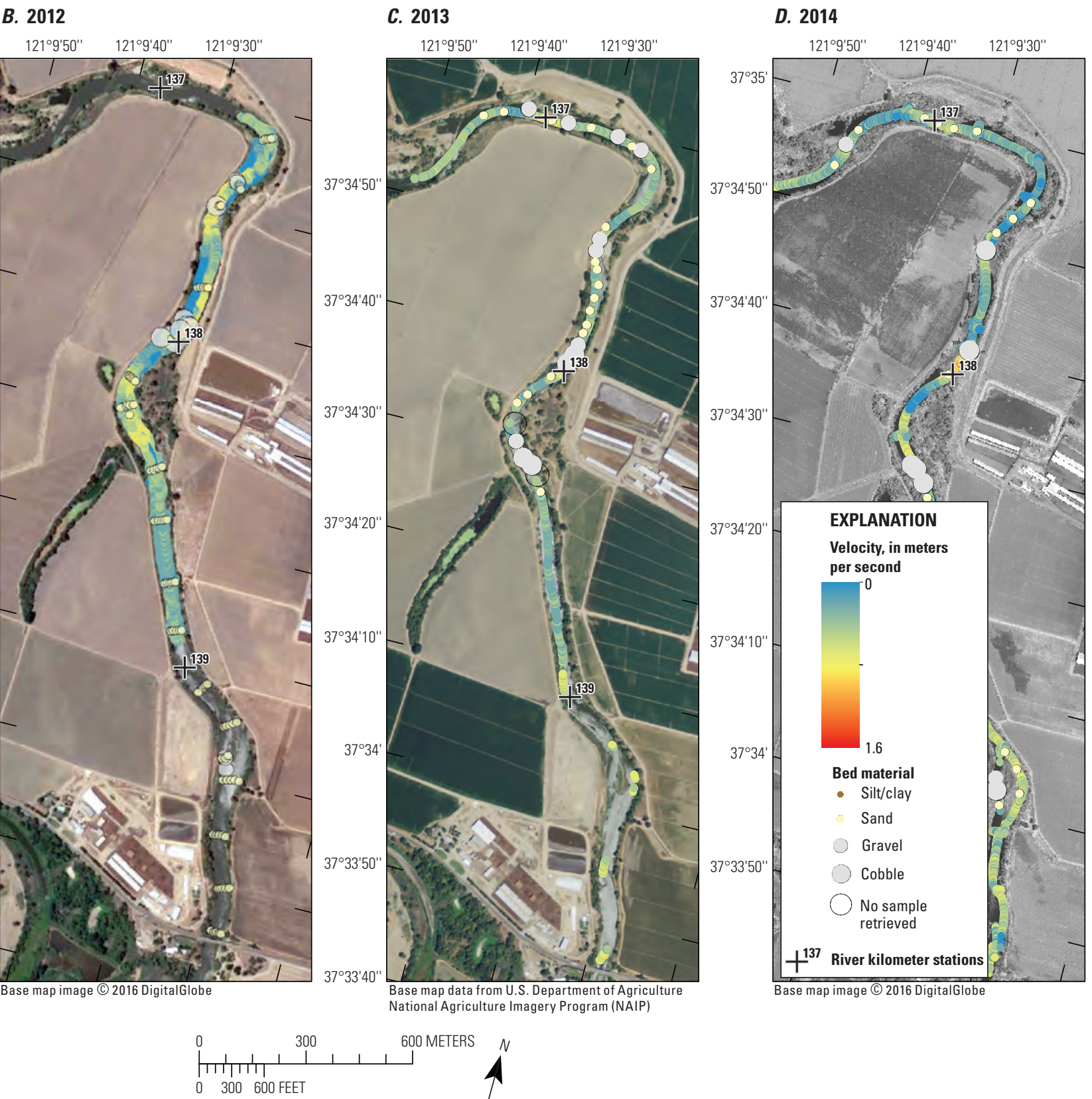
$\stackrel{600 \mathrm{M}}{+}$ 600 METERS $N$

Figure 21. Streamflow depth-averaged velocity and bed-material size class in the Grayson Bridge subreach of the lower San Joaquin River, California (river kilometers 137.3139.9): $A, 2011 ; B, 2012 ; C, 2013$; and $D, 2014$.

w

을. 


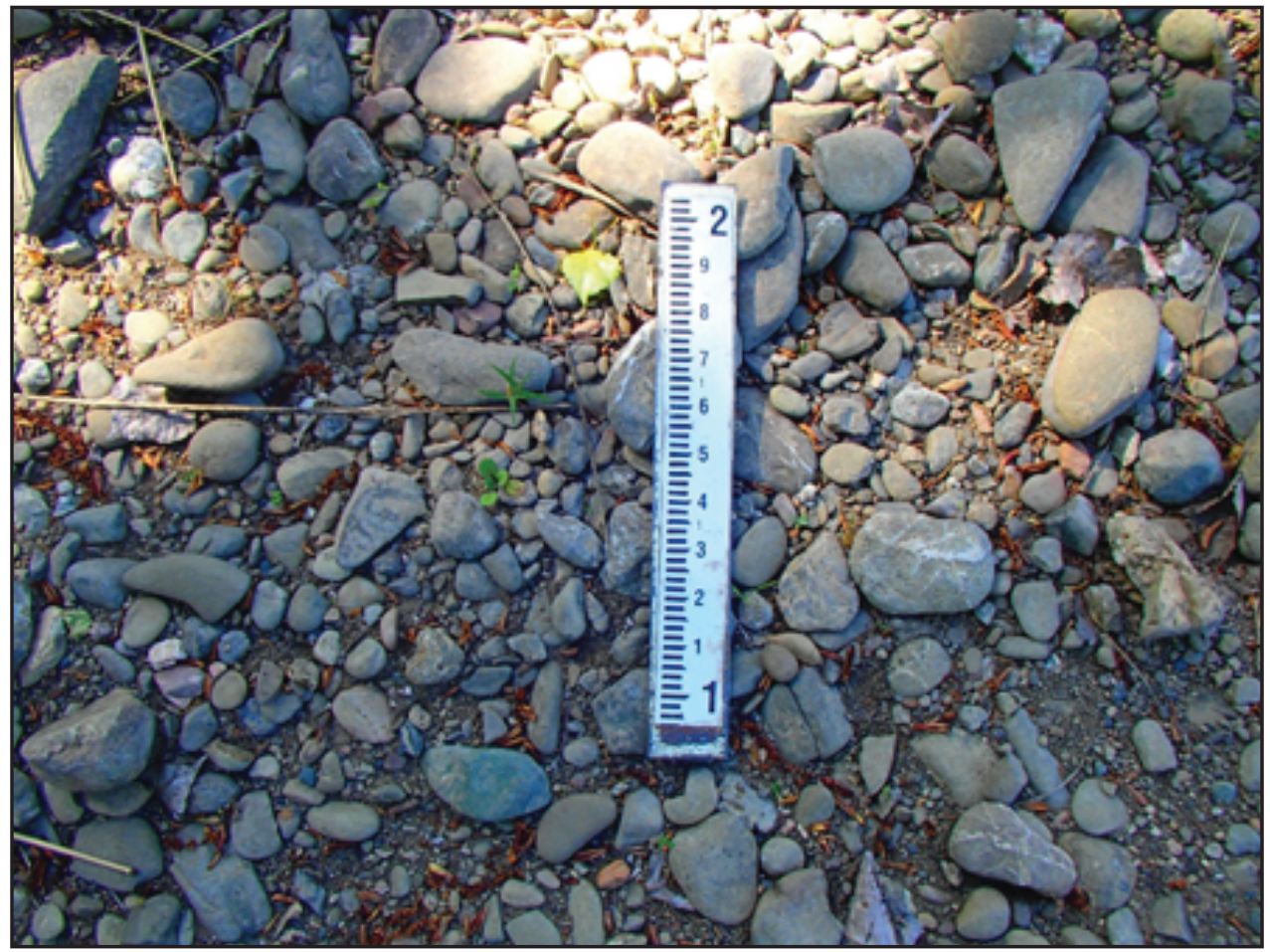

Figure 22. Cobble in the dry bed of Orestimba Creek at Eastin Road (river kilometer 12.8), approximately 5 kilometers northwest of Newman, California, April 24, 2014. The scale in the photograph is about 0.3 meter (1 foot) in length.

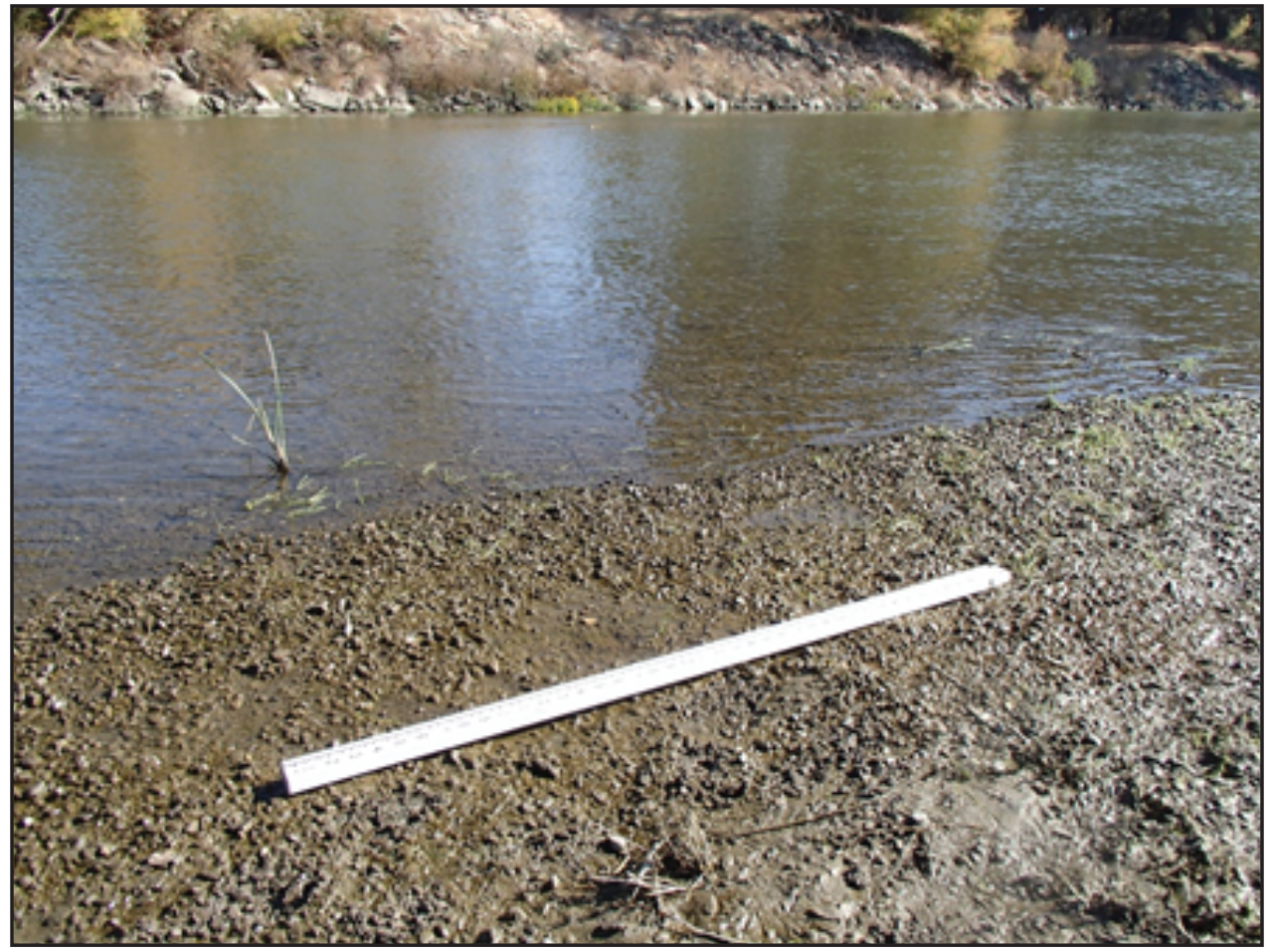

Figure 23. Edge of a large gravel bar in the lower San Joaquin River at river kilometer 146.3, the mouth of Del Puerto Creek, California, November 8,2013 . The scale in the photograph is about 1.2 meters ( 4 feet) in length. 


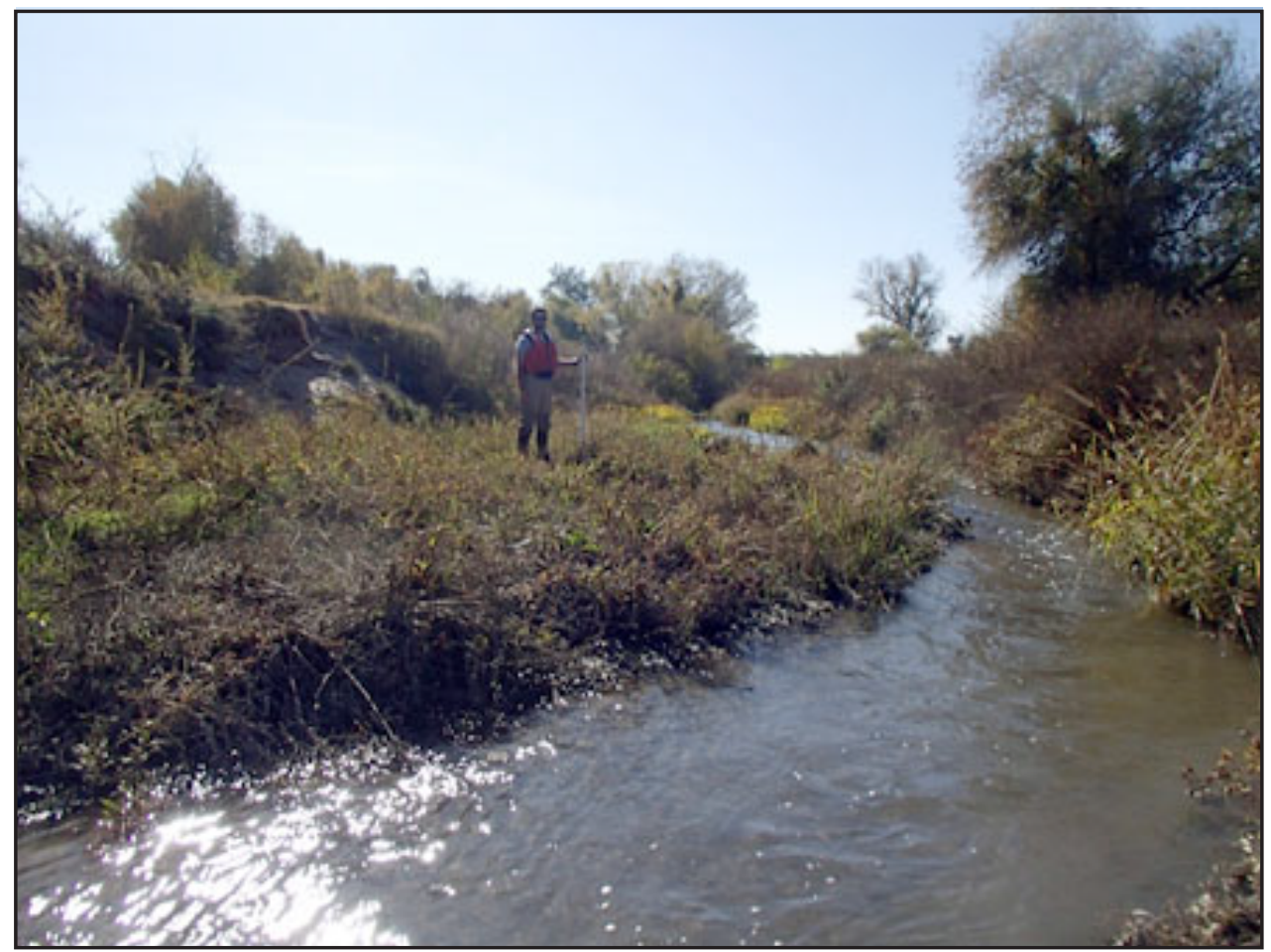

Figure 24. Mouth of Del Puerto Creek, California, November 8, 2013, where the channel cut through a large gravel deposit.

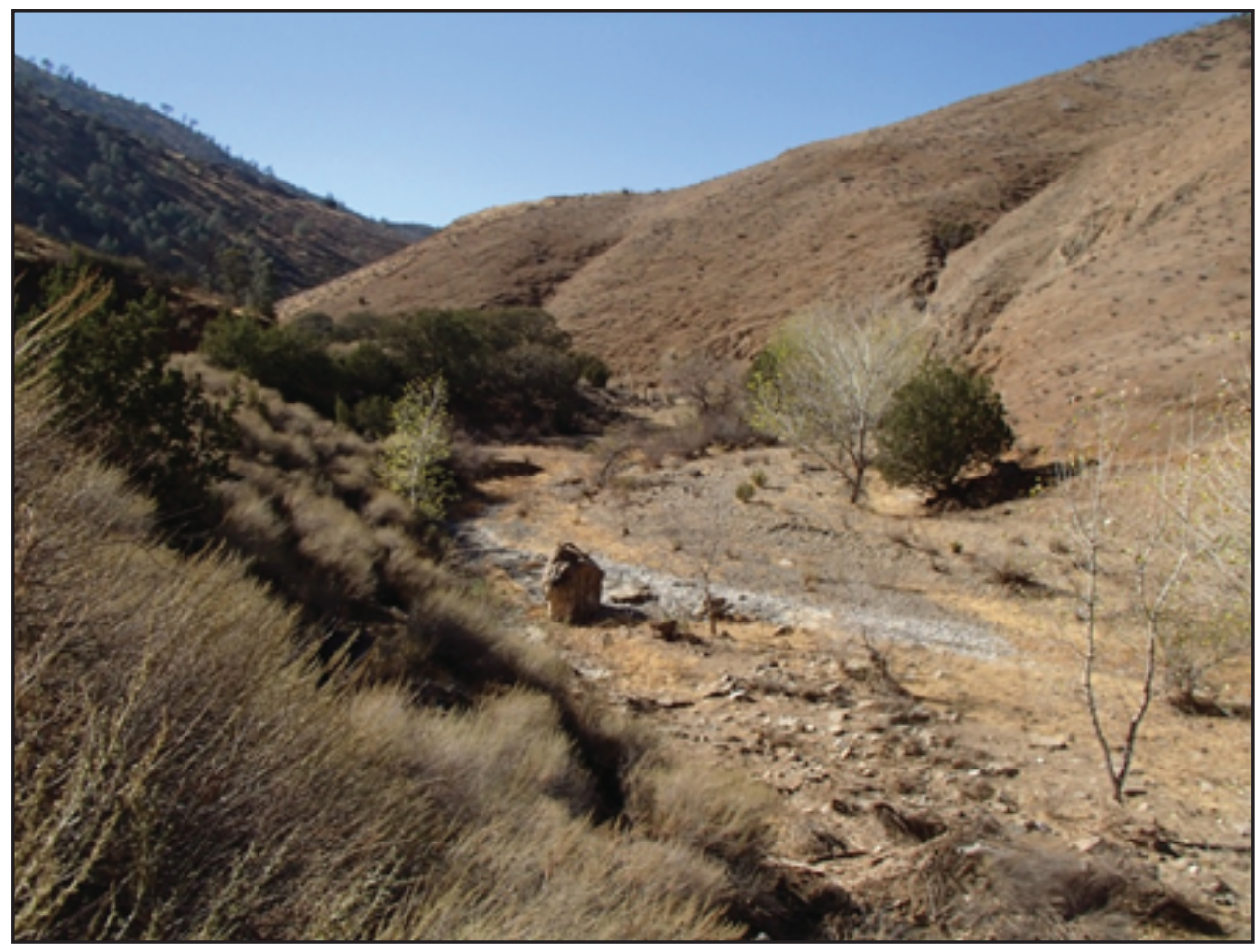

Figure 25. Dry channel bed of Del Puerto Creek, 22 kilometers upstream from its confluence with the lower San Joaquin River, California, November 1, 2013. Gravel- and cobble-size sediment deposits were abundant in the creek bed. 


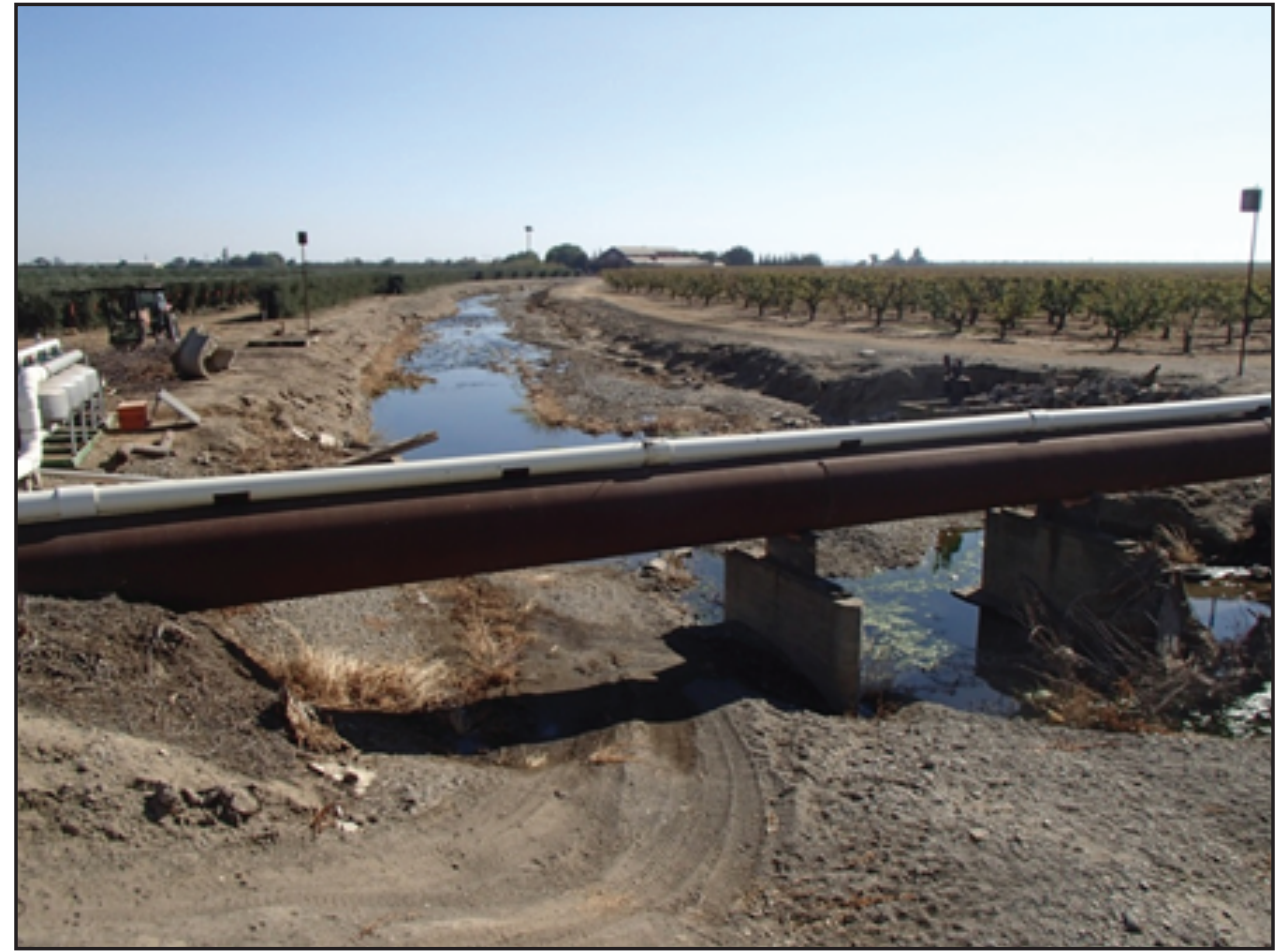

Figure 26. Del Puerto Creek at Rogers Road (8.7 kilometers upstream from its confluence with the lower San Joaquin River, California), November 1, 2013. Deposits of gravel-size sediment were in the channel.

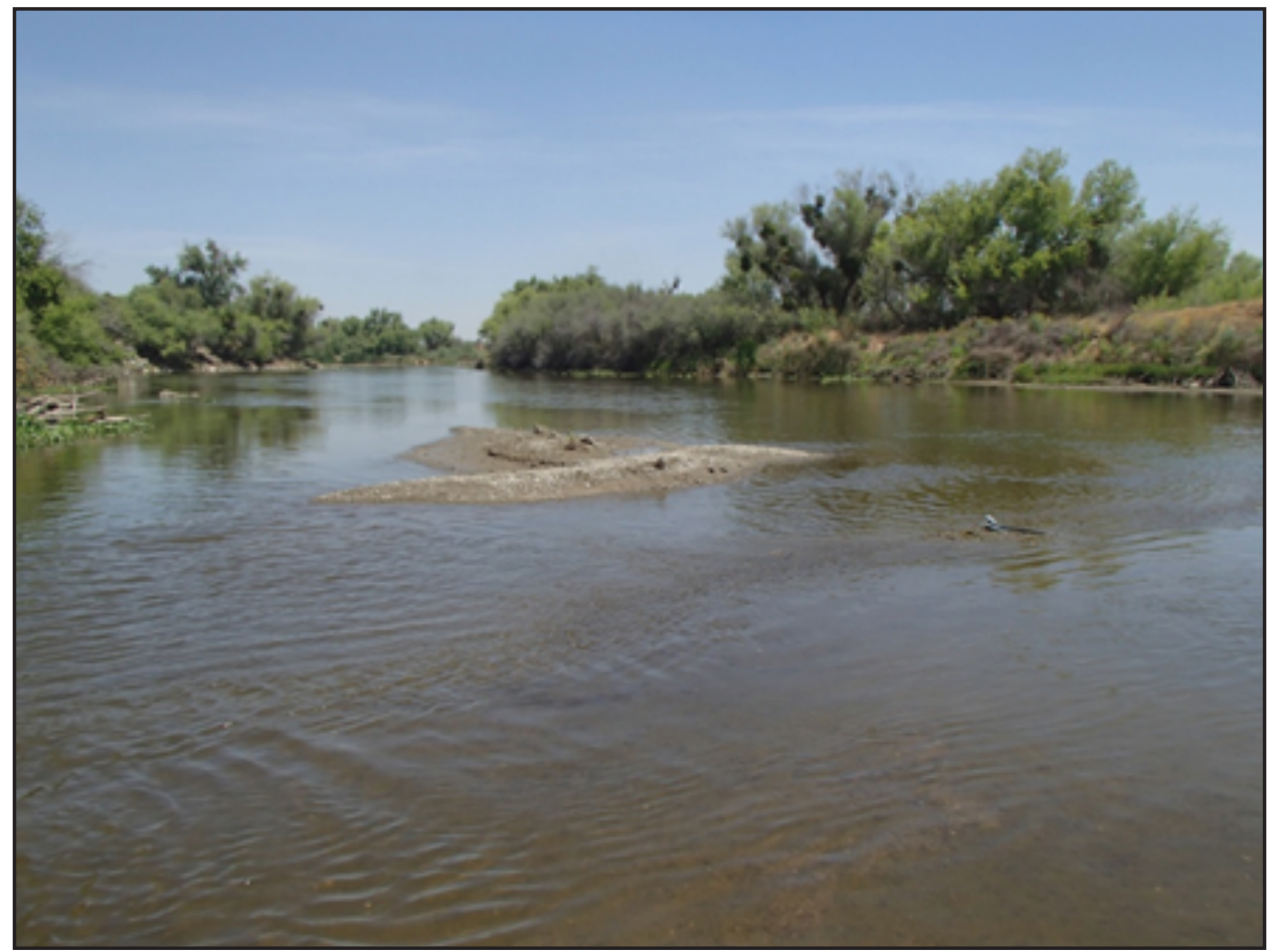

Figure 27. Exposed gravel bar in the lower San Joaquin River, California, near river kilometer 171.8, the mouth of Orestimba Creek, May 13, 2014. The exposed portion is about 4 meters across. 

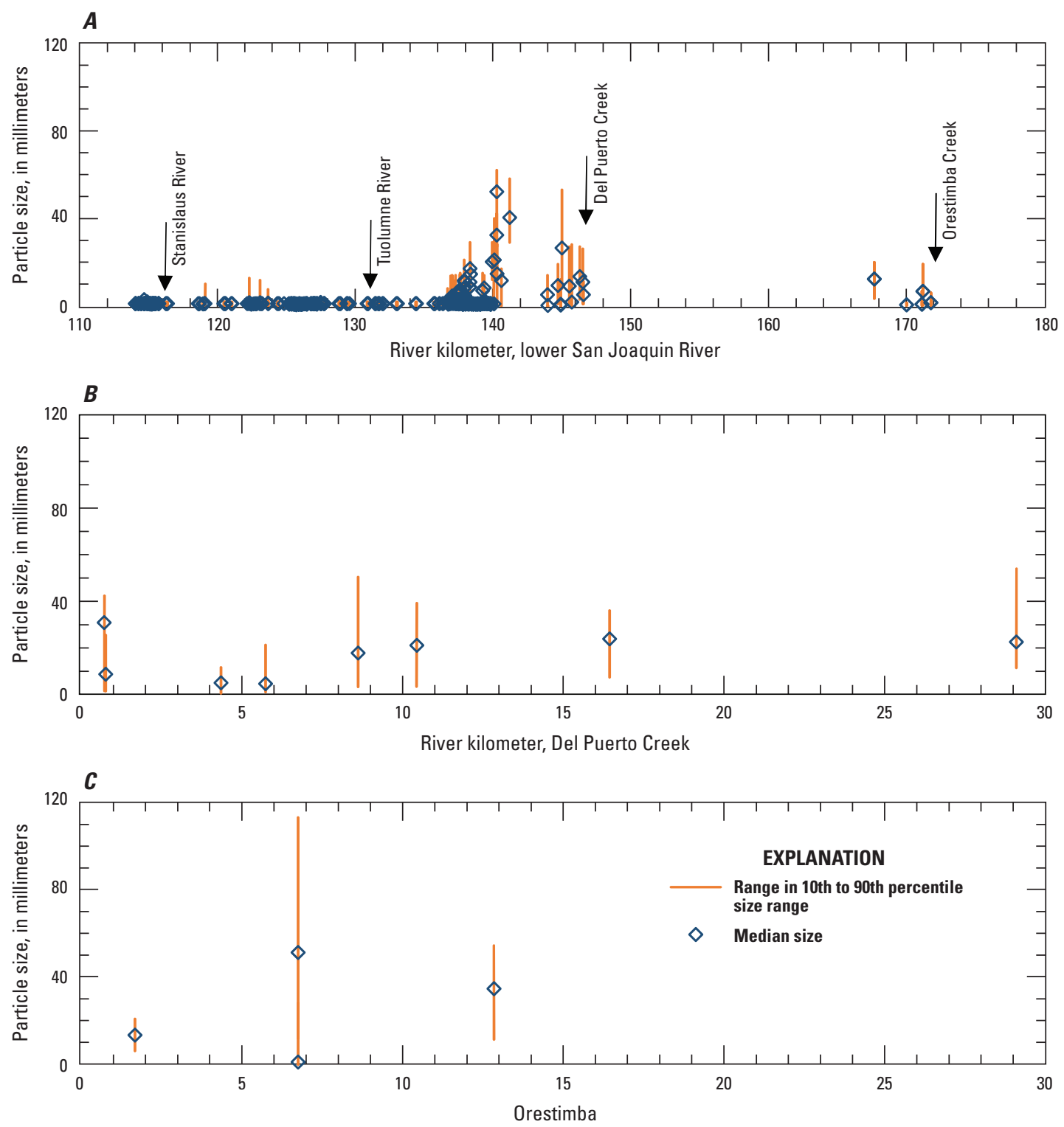

Figure 28. Particle-size distribution of bed-material samples collected from channels during 2011-13: A, lower San Joaquin River; $B$, Del Puerto Creek (enters the San Joaquin River at river kilometer 146.3); and C, Orestimba Creek (enters the San Joaquin River at river kilometer 171.8). 
The dominant bed-material size class in the study areas of the lower San Joaquin River was sand. The Grayson Bridge subreach and an area immediately upstream from the Grayson Road Bridge were the only areas with large quantities of gravel in the streambed. Several exposed gravel bars were observed in this subreach, and gravel-sized bed material was typically found in the channel (as evidenced by bed-material samples) adjacent to those gravel bars. The areas of coarse (gravel-size) bed material in this subreach were separated by larger areas of sand.

Some small lenses of cobble-size sediment were in the banks next to Laird Park (Rkm 139.9-142.0); however, the bank material was not systematically sampled. The lenses of cobble-size sediment near Laird Park were generally less than 1 meter below the top of the bank and, in at least one location, appeared to come from an eroding bank and were mixed with man-made debris (bricks and pieces of metal), the likely remnants of an old levee berm. Because only small quantities of cobble (and no gravel) were observed in the banks, they did not appear to be the likely primary source of the gravel and cobble in the riverbed.

Gravel-size bed material in the lower San Joaquin River appeared to be primarily coming from Del Puerto Creek and, to a lesser extent, Orestimba Creek. Gravel bars were observed in several sites from the Coast Ranges to the lower San Joaquin River along the channel of Del Puerto Creek (figs. 24-26). In the most downstream reach of Del Puerto Creek (approximately 0.8-1.6 km upstream from the confluence), gravel-size sediment was found to depths of at least $10 \mathrm{~cm}$ in the streambed. Some gravelsize bed material was also present in the lower San Joaquin River at a few areas downstream from the confluence with Orestimba Creek (figs. 27, 28). Previous reports described gravel in the lower San Joaquin River only at the confluences (W.P. Smith, Assistant Engineer, to Colonel G.H. Mendell, June 28, 1883, as quoted in Reed and others, 1891, p. 89; Mussetter Engineering, Inc., and others, 2000); however, these reports were probably based only on exposed gravel bars. Samples collected in this study showed the patches of gravel bed material in the lower San Joaquin River extend farther downstream from Del Puerto Creek than from Orestimba Creek. The results plotted by river kilometer in figure 28 show the linear extent of gravel and cobble bed material in samples along the lower San Joaquin River as well as the gradual decrease in gravel and cobble downstream from Del Puerto Creek, where the bed-material composition transitions to nearly all sand and finer material.

\section{Stream Slope}

Because of the relatively flat valley floor, rivers in the Central Valley tend to have a very low gradient and, thus, generally do not have bed shear stresses high enough to transport coarse bed material. As a result, rivers on the Central Valley floor are primarily sand bedded (Mussetter
Engineering, Inc., and others, 2000; Singer and Dunne, 2004; Singer, 2008). The longitudinal elevation profiles of the San Joaquin River, three major east-side tributary rivers (Stanislaus, Tuolumne, and Merced), and two major west-side tributary creeks (Del Puerto and Orestimba) are shown in figure $29 \mathrm{~A}, \mathrm{C}$ ). The profiles show a generally concave-upward, longitudinal elevation profile, which is typical of rivers (Mackin, 1948). The locations of some of the major dams, by river kilometer, also are shown in the profiles.

The channel gradient, which was calculated from the longitudinal profiles, is shown (as smoothed) in figures $29 B$, $29 D$. The channel slopes in the upper watershed of all four rivers (Stanislaus, Tuolumne, Merced, and San Joaquin) varied greatly as they transitioned from the Sierra Nevada to the foothills and then to the Central Valley. The downstream part of each river $(0-50 \mathrm{~km})$ had a gentle slope, generally around 0.0003-0.0005 meters per meter $(\mathrm{m} / \mathrm{m})$. The two creeks (Del Puerto and Orestimba) had slopes of about $0.005-0.010 \mathrm{~m} / \mathrm{m}$, an order of magnitude steeper than the rivers and similar to that of the river reaches upstream from the dams. The steeper gradient of the creeks is due to the shorter distance from their headwaters in the Coast Ranges to the lower San Joaquin River compared to the distance along rivers from their headwaters in the Sierra Nevada. Consequently, the peak flows in steep west-side creeks exert bed shear stresses capable of transporting coarse bed material to the predominantly sandbedded reaches of the lower San Joaquin River.

\section{Bed Aggradation, 2011-14}

Aggradation of bed material in the lower San Joaquin River was observed in many areas during the study period, including Sturgeon Bend (fig. 30), where bathymetric data were collected in all 4 years of this study. Following high flows in 2011, Sturgeon Bend had a 14-m deep pool, which was filled with sediment - as much as about 7-8 m of deposition - by 2014. At the same time, the sand bar on the inner bank of the bend also grew, so that by 2014, the river was confined to a narrow, $1-3-\mathrm{m}$ deep channel near the outer bank of Sturgeon Bend. The arbitrary datum shown in Figures 30 and 31 corresponds roughly to elevation in meters using North American Vertical Datum of 1988. This datum was determined by adjusting the difference in bed elevation surveyed in 2012 and adjusting it corresponding to differences in stage at the nearest streamgage during other longitudinal profiles.

Another area where water depth was measured every year from 2011 to 2014 was the Grayson Bridge subreach (fig. 31). At this site, a sediment wave approximately $2.5-4.0-\mathrm{m}$ in height, composed of sand, advanced downstream at a rate of about 100 meters per year $(\mathrm{m} / \mathrm{yr})$. The channel in this longitudinal section ( $\mathrm{Rkm} 138.8-139.2$ ) is about $35 \mathrm{~m}$ wide. An estimated 9,500 plus or minus 1,000 cubic meters $\left(\mathrm{m}^{3}\right)$ of sediment was deposited each year between 2011 and 2014 in this area. 

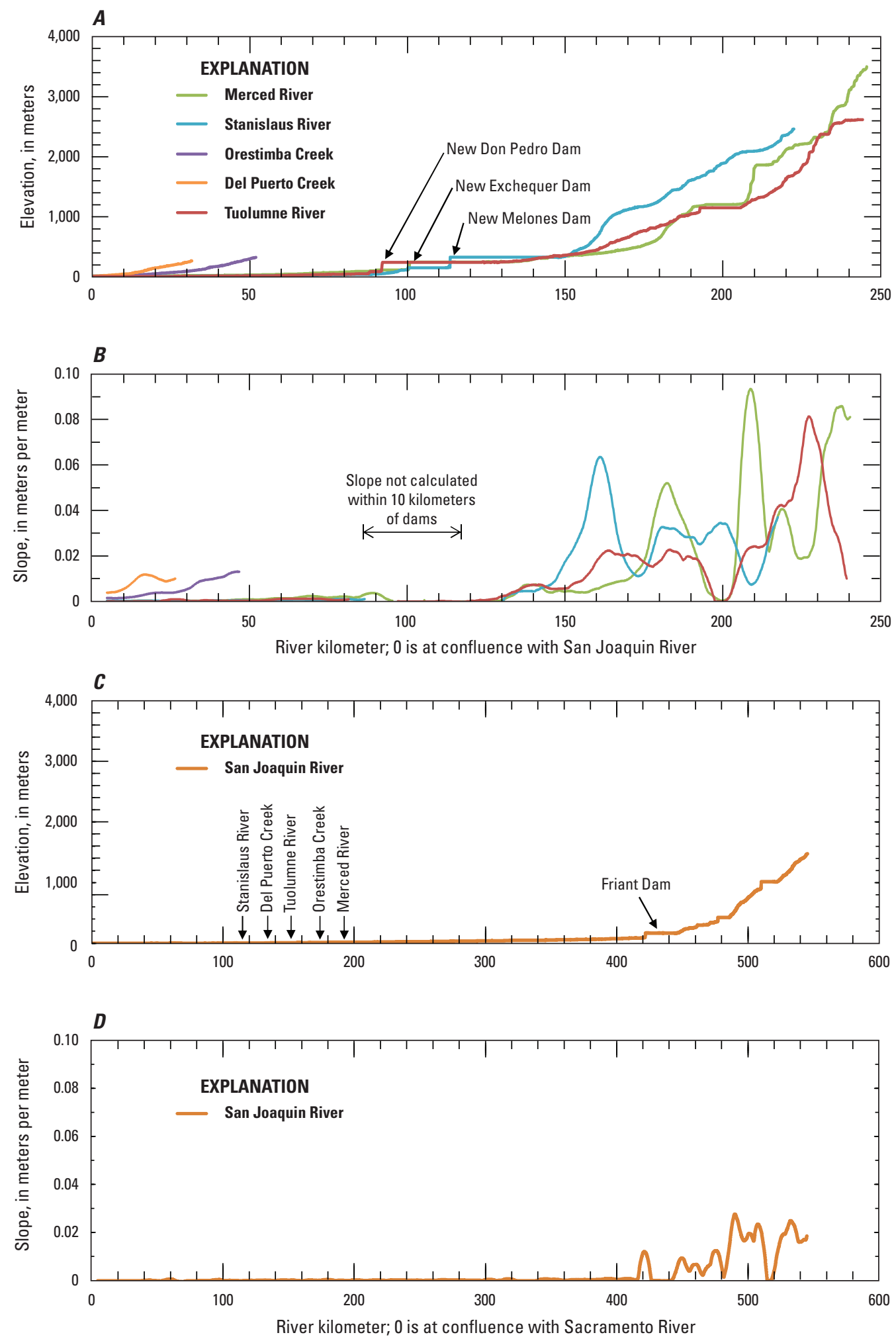

Figure 29. Longitudinal profiles of water-surface elevation, water-surface slope, and principal dams in rivers and creeks of the San Joaquin Basin, California: $A$, elevation of rivers and creeks tributary to the San Joaquin River; $B$, slope of rivers and creeks tributary to the San Joaquin River; $C$, elevation of the San Joaquin River; and D, slope of the San Joaquin River. The water-surface slope was smoothed using a 10-kilometer-averaging window. 


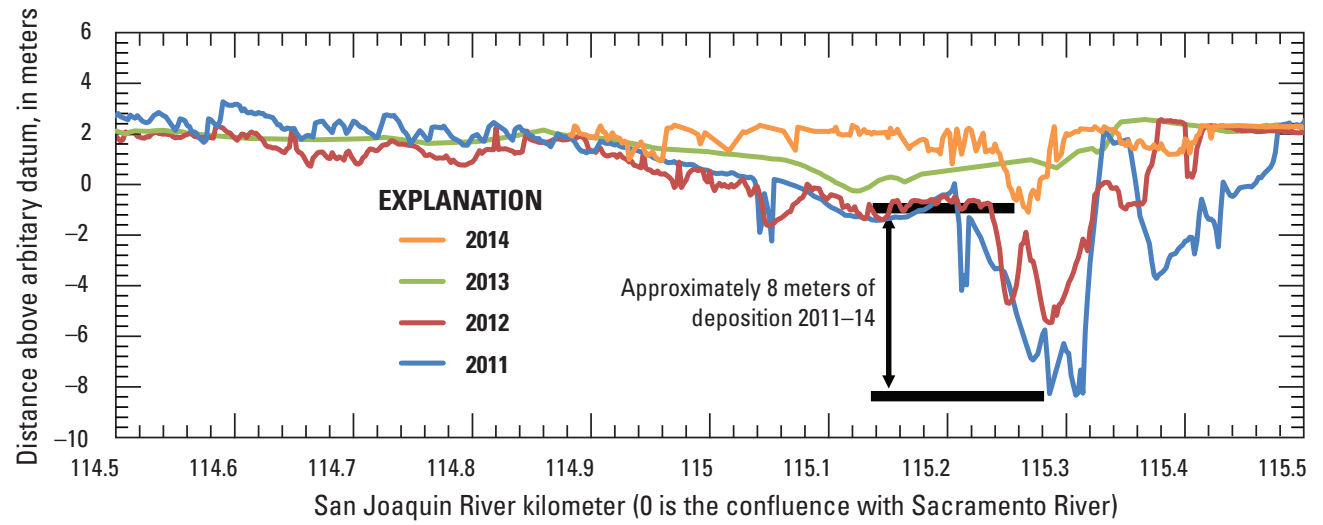

Figure 30. Bed-elevation changes along selected longitudinal section (river kilometers 114.5-115.5) in the Sturgeon Bend subreach, lower San Joaquin River, California, 2011-14. Longitudinal profile in 2013 followed the river centerline, which may not correspond to the deepest part (thalweg) of the river channel.

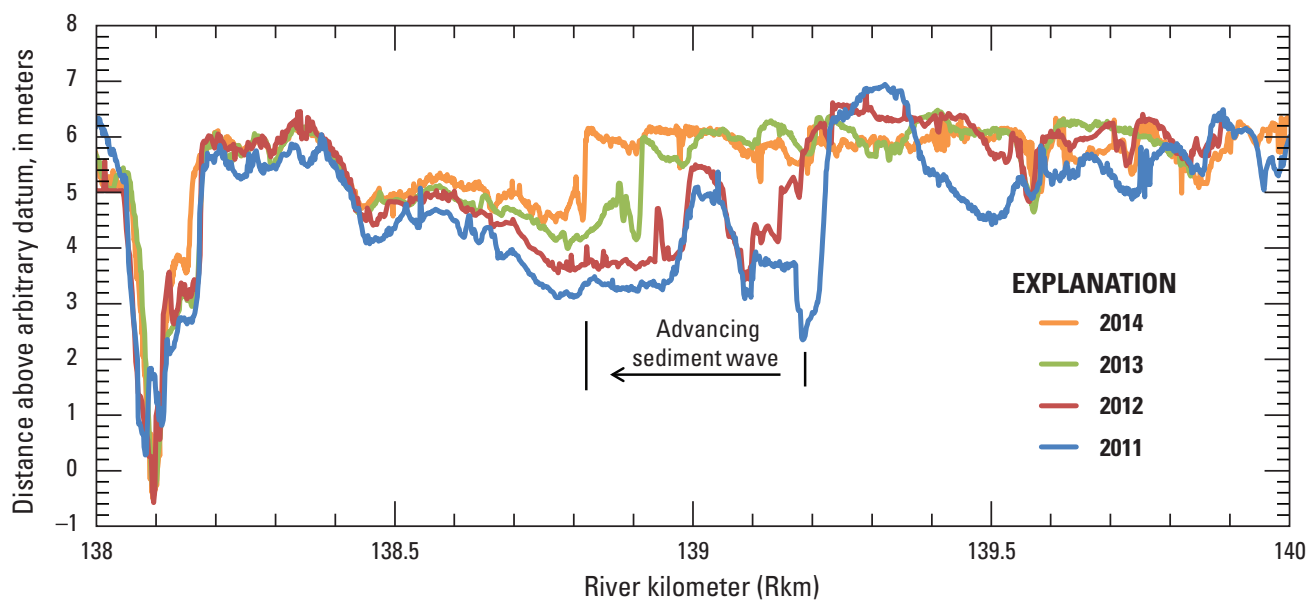

Figure 31. Bed-elevation changes along selected longitudinal section (river kilometers 138-140) in the Grayson Bridge subreach, San Joaquin River, California, 2011-14. Water depths measured each year; bed elevation was approximated from changes in stage at an upstream U.S. Geological Survey streamgage. 


\section{Discussion and Conclusions: Bed Material and Streamflow in the Lower San Joaquin River}

The following section provides interpretation of the results related to (1) gravel in a sand-bedded river, (2) historical changes in hydrology, (3) aggradation of the river bed, and (4) sources of gravel and cobble.

\section{Gravel in a Sand-Bedded River}

The bed-material particle size in most rivers becomes finer downstream as a result of weathering and natural sorting concomitant with downstream decreases in slope; it often transitions between gravel and sand over a short distance (Smith and Ferguson, 1995; Knighton 1998; Ferguson, 2003). The presence of gravel in sand-bedded systems is often attributed to lateral inputs (such as the west-side tributary creeks in this study), but the drivers of coarse (gravel) bedload transport and the fate of such gravel in a sand-bedded river are not well understood. Most likely, the gravel moves slowly downstream, primarily during high flows, in the troughs of sand dunes until it reaches a low point in the river (Hassan and others, 1999; Venditti and others, 2010). Numerical sediment transport modeling can help estimate the sediment transport capacity of the of the lower San Joaquin River and address questions regarding the time required for gravel to be transported downstream from the Del Puerto reach.

\section{Changes in Hydrology}

We analyzed several years of peak-flow data and daily average stream discharge data (figs. 6,7) and determined that the upstream dams reduced peak flows during most water-year types. Although runoff from the largest storms is not completely captured in reservoirs, the reservoir floodcontrol capacity seems to be sufficient to capture runoff from many of the small- to mid-size storms. The resulting effect is that average peak streamflow has been lower after dam construction for all water year types except for critical years, and the time between peak flows of similar magnitude has lengthened. The low peak flows during low-flow water years also could affect sediment transport and long-term sediment storage in the lower San Joaquin River.

\section{Aggradation of the River Bed}

Aggradation of sand in the lower San Joaquin River during the low-flow water years of this study could decrease the availability of accessible gravel to sturgeon for spawning until subsequent high-flows scour the bed. Because sedimentation was recorded in the lower San Joaquin River even during dry years in some of areas in this study, and gravel migrates downstream through dune troughs until it reaches low points in the river, it is possible that gravel and cobble are in many sections of the river, but were buried and remained undetected during the 2012-14 bed-material sampling. If lenses of gravel and cobble are present beneath layers of sand, then high flows (such as those during 2011) could expose them, thereby increasing the sturgeon spawning habitat.

High stream discharge in July 2011 was associated with high water velocity (fig. 15); in water year 2011. This likely caused erosion which was followed by deposition during low flows. Deposition during the subsequent years indicates that sediment supply exceeds the transport capacity during those low-flow years. Hence, greater sediment-transport capacity during high-flows could evacuate sand from pools, access and potentially mobilize any underlying gravels, and cause deep scour holes, particularly at sharp meander bends (like Sturgeon Bend), as mobility thresholds for bed sediment are exceeded.

During low-flow years, the accumulation of sandsize sediment in the lower San Joaquin River could affect spawning habitat by filling in deep scour holes and by infiltrating the interstitial spaces or completely burying spawning gravels. Evaluation of sediment transport and bed evolution under a range of flow conditions, water-year types, and upstream reservoir flow-release scenarios could provide information about the conditions needed to establish and maintain sturgeon-breeding habitat in the lower San Joaquin River.

\section{Sources of Gravel and Cobble}

Bed material was sampled in many locations from 2012 to 2014. The bed of the lower San Joaquin River was predominately sand, except in the Del Puerto reach. In the Del Puerto reach, several exposed gravel bars and large patches of gravel were in the channel from the mouth of Del Puerto Creek and extending downstream approximately $10 \mathrm{~km}$. Conversely, only a single exposed gravel bar was found at the mouth of Orestimba Creek, and only a few patches of gravel were found in the Orestimba Creek reach. It is possible that Orestimba Creek had delivered large quantities of gravel that were buried beneath sand at the time of this study. We did not evaluate the long-term stability of gravel bars, downstreammigration rates of gravel material, or the sediment-delivery rate of the tributary creeks. A sediment-transport study could evaluate these factors. 
Several deep scour holes were measured in the 2011 survey, including Sturgeon Bend; however, no bedmaterial samples were collected that year. As a result, we could not determine whether coarse bed material in those areas was buried in later years. Given the distance from Del Puerto Creek, it seems likely that coarse bed material was buried in the channel before it could migrate downstream to some of the deep scour holes measured in 2011. In the major tributaries, the bed-material transitions to sand several kilometers before the confluence with the lower San Joaquin River. With damregulated streamflow regimes, it is unlikely that the larger tributaries are important sources of gravel or cobble sediment to the lower San Joaquin River.

Although gravel and cobble were found in the dry creek beds of Del Puerto and Orestimba Creeks, evidence indicated that Del Puerto Creek was the primary source of coarse bed material to the lower San Joaquin River and that Orestimba Creek did not appear to contribute much coarse bedload sediment.

Del Puerto Creek has a smaller watershed than Orestimba Creek, so it is not clear why Del Puerto Creek would deliver more coarse sediment to the lower San Joaquin River than Orestimba Creek. One possibility is that Orestimba Creek cannot transport as much coarse sediment as Del Puerto Creek because the channel slope is gentler in Orestimba Creek. The slope of the lower $10 \mathrm{~km}$ of Orestimba Creek was about $0.002 \mathrm{~m} / \mathrm{m}$, whereas the slope of Del Puerto Creek was about $0.004 \mathrm{~m} / \mathrm{m}$ (fig. 29B). Another possibility is that the hydrologic and geomorphic history prior to the study period differed between the two watersheds. A third possibility is that peak flow near the mouth of the stream is much less than that near the mountains (fig. $6 E$ ). Orestimba Creek has been heavily modified by gravel mining and agricultural encroachment, which have changed the channel geometry and altered the natural sediment-transport regime (United States Army Corps of Engineers, 2013). During floods, streamflow can spill over the creek banks where the channel reaches the San Joaquin Valley floor and spread onto the floodplains (United States Army Corps of Engineers, 2013), which could reduce the transport capacity of the channel. As the primary, modern-day source of gravel and cobble bed material to the lower San Joaquin River, Del Puerto Creek appears to be important for the spawning success of sturgeon by supplying gravel for spawning habitat.

\section{Summary}

Decreases in the San Francisco Bay estuary white sturgeon population have led to an increased effort to understand their migration behavior and habitat preferences. Coarse bed material (gravel and cobbles), in particular, is important for the survival of white sturgeon eggs and larvae. Evidence of spawning by white sturgeon (Acipenser transmontanus) in the lower San Joaquin River has recently been documented (2011-12) by the U.S. Fish and Wildlife Service. Knowledge of the physical characteristics of the lower San Joaquin River can be used to preserve sturgeon spawning habitat and lead to management decisions that could help increase the San Francisco Bay estuary white sturgeon population.

In order to characterize the hydraulic conditions and bed composition of the lower San Joaquin River reaches where sturgeon spawned, the U.S. Geological Survey (USGS) initiated scientific investigations, in cooperation with the U.S. Fish and Wildlife Service (USFWS), of selected reaches and tributaries of the lower river. This report documents the methods and findings of the 4-year study by (1) describing selected spawning reaches in terms of habitat-related physical characteristics (such as water depth and velocity, channel slope, and bed material) of the lower San Joaquin River between its confluences with the Stanislaus and Merced Rivers; (2) describing variations in these physical characteristics during wet and dry years; and (3) identifying potential reasons for these variations.

During high-flow periods, a substantial part of the San Joaquin River streamflow is diverted at the San Joaquin River Control Structure, but the diverted water eventually returns to the San Joaquin River through the Mariposa Bypass, where the lower San Joaquin River is considered to begin, 234 river kilometers (Rkm 234) upstream from its confluence with the Sacramento River. The lower river is a low-gradient, single-channel, meandering river. Streamflow in the lower San Joaquin River is primarily derived from the middle San Joaquin River (through the Mariposa Bypass) and from three tributary rivers flowing west from the Sierra Nevada, all regulated by dams. In contrast, tributary creeks flowing east from the Coast Ranges generally are not dammed and are ephemeral. Streamflow in the lower river is also affected by numerous agricultural diversions.

The lower San Joaquin River was divided into five study reaches, named for the tributary confluences at their upstream ends. In upstream order, the study reaches were the Stanislaus, Tuolumne, Del Puerto, Orestimba, and the Merced. Although data were collected from all study reaches, of special interest were three subreaches where the USFWS collected viable eggs at multiple sites they sampled in 2011-12. In upstream order, the subreaches were Sturgeon Bend (Rkm 114.0-116.3), Old Fisherman's Club (Rkm 125.2-127.5), and Grayson Bridge (Rkm 137.3-139.9). The USGS collected data for 3 to 4 years in those three subreaches, whereas in other reaches, data often were collected only for 1 or 2 years. The study data were collected during spring through summer of 4 water years during which runoff ranged from wet in 2011 and dry in 2012 to critical in 2013 and 2014. Data collection included approximately 105 channel cross sections and measured water depth and velocity in a total of 92 river kilometers by collecting nearly 150,000 depth-averaged water velocity measurements and 246,000 water-depth measurements. 
Water depth was measured by soundings using a multibeam sonar and an ADCP. Depth and velocity data were collected using two different approaches: channel cross sections and longitudinal profiles. Bed forms and texture were imaged using side-scan sonar. Longitudinal elevation profiles of the San Joaquin River, three major east-side tributary rivers (Stanislaus, Tuolumne, and Merced), and two west-side tributary creeks (Del Puerto and Orestimba) were constructed using elevation data from the National Elevation Dataset and centerlines from the National Hydrography Dataset. Bed material generally was sampled from boats using a rotaryscoop bed-material sampler; thus, the surface layer of the bed was sampled, nominally to a depth of $5 \mathrm{~cm}$. Particlesize distribution of the bed material was determined using a combination of sieving (five mesh sizes for the fraction less than $2 \mathrm{~mm}$ ) and direct manual measurement. That is, particles larger than $2 \mathrm{~mm}$ were sorted manually and sized using a template (SAH-97 analyzer). Particles were classified using a generalized Wentworth scale as fine sediment (smaller than $0.063 \mathrm{~mm}$, silt and clay), sand (0.063 to less than $2 \mathrm{~mm}$ ), gravel ( 2 to less than $64 \mathrm{~mm}$ ), and cobble (64 to less than $256 \mathrm{~mm})$.

The bed of the lower San Joaquin River was predominately sand, but had areas of gravel. The hydrology of the lower San Joaquin River has been altered by the construction of several major dams on its tributary rivers. How these alterations in hydrology have affected long-term sediment-transport dynamics in the lower San Joaquin River was not determined, but this study documented aggradation in three subreaches during the 3 years following 2011 (a wet year). The aggradation of fine sediment during low-flow water years could reduce the availability of clean, exposed, coarse bed material for sturgeon to use during spawning. Coarse bed material was found in patches separated by large areas of sand. The gravel is likely to migrate slowly downstream, primarily during high flows, in the troughs of sand dunes until it reaches a low point in the river. Additional work would be required to quantify the supply of coarse sediment, estimate transport rates, and determine the fate of coarse sediment in the lower San Joaquin River.

The principal source of gravel and cobble was determined to be Del Puerto Creek and, to a lesser degree, Orestimba Creek (on the basis of locations of coarse material in the bed of the lower San Joaquin River, the proximity to the confluences with these two creeks, and presence of coarse bed material in the two creeks). Because Del Puerto Creek was the primary source of coarse sediment to the lower San Joaquin River in this study, it is important to the long-term spawning success of sturgeon in the lower San Joaquin River.

\section{References Cited}

Austin, Geoffrey, 2012, Essential spawning habitat for Atlantic sturgeon in the James River, Virginia: Richmond, Virginia Commonwealth University, Master's thesis, 42 p., http://scholarscompass.vcu.edu/etd/2843/.

Barton, G.J., 2004, Characterization of channel substrate, and changes in suspended-sediment transport and channel geometry in white sturgeon spawning habitat in the Kootenai River near Bonners Ferry, Idaho, following the closure of Libby Dam: U.S. Geological Survey WaterResources Investigations Report 2003-4324, 24 p., https://pubs.er.usgs.gov/publication/wri034324.

Billard, Roland, and Lecointre, Guillaume, 2000, Biology and conservation of sturgeon and paddlefish: Reviews in Fish Biology and Fisheries, v. 10, no. 4, p. 355-392, http://dx.doi.org/10.1023/A:1012231526151.

Birstein, V.J., 1993, Sturgeon and paddlefishesThreatened fishes in need of conservation: Conservation Biology, v. 7, no. 4, p. 773-787, http://dx.doi.org/10.1046/j.1523-1739.1993.740773.x.

California Department of Water Resources, 2010, State plan of flood control descriptive document: Sacramento, Calif., Department of Water Resources, Central Valley Flood Management Planning Program, 170 p., http://www.water.ca.gov/cvfmp/docs/DRAFT_SPFC_ Descriptive_Doc_20100115.pdf.

California Department of Water Resources, 2015, WSIHIST (03/21/17 0918)_Chronological reconstructed Sacramento and San Joaquin Valley, water year hydrologic classification indices, 1901-2014: Dept. of Water Resources data tables, accessed April 2015 at http://cdec.water.ca.gov/cgi-progs/iodir/wsihist.

California Regional Water Quality Control Board, 1989, Water diversion and discharge points along the San Joaquin River-Mendota Pool Dam to Mossdale Bridge, Volume 1, Main Report: Sacramento, Calif., California Regional Water Quality Control Board, 50 p., http://www.waterboards. ca.gov/rwqcb5/water_issues/swamp/historic_reports_and faq_sheets/hydrology/sjr_vol1_main_report_89.pdf.

Committee on the Status of Endangered Wildlife in Canada (COSEWIC), 2012, COSEWIC assessment and update status report on the White Sturgeon Acipenser transmontanus in Canada: Ottawa, Ontario, Canada, Committee on the Status of Endangered Wildlife in Canada, 75 p., http://www.sararegistry.gc.ca/virtual_sara/files/ cosewic/sr_white_sturgeon_e.pdf. 
Conte, F.S., Doroshov, S.I., Lutes, P.B., and Strange, E.M., 1988, Hatchery manual for the White Sturgeon Acipenser transmontanus Richardson with application to other North American Acipenseridae: Oakland, Calif., The Regents of the University of California, Division of Agriculture and Natural Resources, Publication 3322, 119 p., http://www.fishsciences.net/projects/columbia_sturgeon/_ pdfs/18-Hatchey_manul_wh-sturg.pdf.

Davis, B.E., 2005, A guide to the proper selection and use of federally approved sediment and water-quality samplers: U.S. Geological Survey Open-File Report 2005-1087, 20 p., https://pubs.er.usgs.gov/publication/ofr20051087.

Dettinger, M.D., Ralph, F.M., Das, Tapash, Neiman, P.J., and Cayan, D.R., 2011, Atmospheric rivers, floods and the water resources of California: Water, v. 3, no. 2, p. 445-478, http://dx.doi.org/10.3390/w3020445.

Edwards, T.K., and Glysson, G.D., 1999, Field methods for measurement of fluvial sediment: U.S. Geological Survey Techniques of Water-Resources Investigations, book 3, chap. C2, 89 p., https://pubs.er.usgs.gov/publication/twri03C2.

Ferguson, R.I., 2003, Emergence of abrupt gravel to sand transitions along rivers through sorting process: Geology, v. 31, no. 2, p. 159-162, http://geology.gsapubs.org/content/31/2/159.short.

Gadomski, D.M., and Parsley, M.J., 2005, Effects of turbidity, light level, and cover on predation of white sturgeon larvae by prickly sculpins: Transactions of the American Fisheries Society, v. 134, no. 2, p. 369-374, http://dx.doi.org/10.1577/T03-213.1.

Gard, Mark, 1996, Sacramento River white sturgeon spawning criteria: Sacramento, Calif., U.S. Fish and Wildlife Service, Ecological Services, 13 p., http://personales.upv.es/fmcapel/ data/Sacramento\%20River\%20White $\% 20$ Sturgeon $\% 20$ Spawning\%20Criteria\%20Feb\%2014,\%201996.pdf.

Grimes, Hiram, 1858, Diseño del Rancho El Pescadero, California: U.S. District Court, California, Northern District, Land case 137, Land case map B-320, p. 108, scale 1:146,850, available through University of California, Berkeley, Bancroft Library, at http://content.cdlib.org/.

Gross, M.R., Repka, Joe, Robertson, C.T., Secor, D.H., and Van Winkle, Webb, 2002, Sturgeon conservationInsights from elasticity analysis, in Winkle, W.V., ed., Biology, management, and protection of North American sturgeon: Proceedings of the American Fisheries Society Symposium, v. 28, p. 183-200, http://labs.eeb.utoronto.ca/gross/Grossetal2002.pdf.
Gruber, J.J., Jackson, Z.J., and Van Eenennaam, J.P., 2012, 2011 San Joaquin River sturgeon spawning survey, Final annual report: U.S. Fish and Wildlife Service, 28 p., https://www.fws.gov/sfbaydelta/documents/2011\%20 San\%20Joaquin\%20River\%20Sturgeon\%20Spawning\%20 Survey.pdf.

Guy, H.P., 1969, Laboratory theory and methods for sediment analysis-Laboratory analysis: U.S. Geological Survey, Techniques of WaterResources Investigations, book 5, chap. C1, 59 p., https://pubs.usgs.gov/twri/twri5c1/pdf/TWRI_5-C1.pdf.

Hall, W.H., 1886, Topographical and irrigation map of the San Joaquin Valley: California State Engineering Department, sheets no. 1-2, scale 1:190,000, accessed March 28, 2017, at http://www.davidrumsey.com/luna/ servlet/view/search?q=pub_list_no $=5833.000 \% 20$ LIMIT:RUMSEY 8 1\&sort=Pub List No InitialSort,Pub_Date,Pub_List_No,Series_No.

Hassan, M.A., Schick, A.P., and Shaw, P.A., 1999, The transport of gravel in an ephemeral sandbed river: Earth Surface Processes and Landforms, v. 24, no. 7, p. 623-640, http://dx.doi.org/10.1002/(SICI)10969837(199907)24:7<623::AID-ESP978>3.0.CO;2-2.

Hildebrand, L., McLeod, C., and McKenzie, S., 1999, Status and management of white sturgeon in the Columbia River in British Columbia, Canada-An overview: Journal of Applied Ichthyology, v. 15, nos. 4-5, p. 164-172, http://dx.doi.org/10.1111/j.1439-0426.1999.tb00227.x.

Jackson, Z.J., and Van Eenennaam, J.P., 2013, 2012 San Joaquin River sturgeon spawning survey_-Final annual report: U.S. Fish and Wildlife Service, 34 p., https://www.fws.gov/sfbaydelta/documents/2012\%20 San\%20Joaquin\%20River\%20Sturgeon\%20Spawning\%20 Survey.pdf.

Jackson, Z.J., Gruber, J.J., and Van Eenennaam, J.P., 2016, White sturgeon spawning in the San Joaquin River, California, and effects of water management: Journal of Fish and Wildlife Management, v. 7, no. 1, p. 171-180, http://www.fwspubs.org/doi/pdf/10.3996/092015JFWM-092.

Johnson Outdoors Marine Electronics Inc., 2014, Description of GPS system: Eufaula, Ala., Johnson Outdoors, accessed June 1, 2016, at http://www.humminbird.com/Category/ Technology/GPS/.

Kaeser, A.J., Litts, T.L., and Tracy, T.W., 2012, Using lowcost side-scan sonar for benthic mapping throughout the Lower Flint River, Georgia, USA: River Research and Applications, v. 29, no. 5, p. 634-644, http://dx.doi.org/10.1002/rra.2556. 
Klimley, A.P., Chapman, E.D., Cech, J.J. Jr., Cocherell, D.E., Fangue, N.A., Gingras, Marty, Jackson, Zachary, Miller, E.A., Mora, E.A., Poletto, J.B., Schreier, A.M., Seesholtz, Alicia, Sulak, K.J., Thomas, M.J., Woodbury, David, and Wyman, M.T., 2015, Sturgeon in the Sacramento-San Joaquin Watershed-New insights to support conservation and management: San Francisco Estuary and Watershed Science, v. 13, no. 4, p. 1-19, http://escholarship.org/uc/item/7892b2wp.

Knighton, A.D., 1998, The gravel-sand transition in a disturbed catchment: Geomorphology, v. 27, no. 3-4, p. 325-341, https://doi.org/10.1016/S0169555X(98)00078-6.

Kock, T.J., Congleton, J.L., and Anders, P.J., 2006, Effects of sediment cover on survival and development of white sturgeon embryos: North American Journal of Fisheries Management, v. 26, no. 1, p. 134-141, http://dx.doi.org/10.1577/M05-073.1.

Kohlhorst, D.W., 1976, Sturgeon spawning in the Sacramento River in 1973, as determined by distribution of larvae: California Fish and Game, v. 62, no. 1, p. 32-40, http://www.calwater.ca.gov/Admin_Record/C-051278.pdf.

Kondolf, G.M., 1997, Profile: Hungry water-Effects of dams and gravel mining on river channels: Environmental Management, v. 21, no. 4, p. 533-51, http://www.wou.edu/las/physci/taylor/g407/kondolf_97.pdf.

Mackin, J.H., 1948, Concept of the graded river: Geological Society of America Bulletin, v. 59, no. 5, p. 463-512, http://gsabulletin.gsapubs.org/content/59/5/463.short.

Marineau, M.D., Wright, S.A., Wheldon-Haught, D.R., and Kinzel, P.J., 2017, Water depth, depth-averaged water velocity, and river centerline stationing in select locations in the lower San Joaquin River, California, 2011-2014: U.S. Geological Survey data release, https://doi.org/10.5066/F7W66HWW.

McAdam, S.O., 2011, Effects of substrate condition on habitat use and survival by white sturgeon (Acipenser transmontanus) larvae and potential implications for recruitment: Canadian Journal of Fisheries and Aquatic Sciences, v. 68 , no. 5, p. 812-822, https://doi.org/10.1139/f2011-021.

Moore, S.B., Winckel, Joy, Detwiler, S.J., Klasing, S.A., Gaul, P.A., Kanim, N.R., Kesser, B.E., DeBevec, A.B., Beardsley, Karen, and Puckett, L.K., 1990, Fish and wildlife resources and agricultural drainage in the San Joaquin Valley, California: Sacramento, Calif., San Joaquin Valley Drainage Program, v. I and II, 935 p., plus appendices.
Moyle, P.B., 2002, Inland fishes of California (revised and expanded): Berkeley, University of California Press, 413 p., http://www.waterboards.ca.gov/water_issues/programs/ tmdl/records/state_board/1998/ref2608.pdf.

Mussetter Engineering, Inc., and Jones and Stokes Associates, Inc., 2000, Sacramento and San Joaquin River Basins comprehensive study, California-Geomorphic and sediment baseline evaluation of the San Joaquin River from the Delta to the confluence with the Merced River and major tributaries, final report: U.S. Army Corps of Engineers, Sacramento District, California, Contract No. DACW0598-D-0020, Task Order No. 008, 192 p., http://www.water. ca.gov/orovillerelicensing/docs/FEIR_080722/AppendixA/ Technical_Studies_Documentation_Dec_02/Supplemental_ Reports/SJR_Sediment_Eval_Report_4-2000.pdf.

National Oceanic and Atmospheric Administration, 1985, Climates of the states-Narrative summaries, tables, and maps for each state, with overview of state climatologist programs (3d ed.): Detroit, Mich., Gale Research Co., v. $1-2$.

Nelson, T.C., Gazey, W.J., English, K.K., and Rosenau, M.L., 2004, Status of white sturgeon in the lower Fraser RiverReport on the findings of the lower Fraser River white sturgeon monitoring and assessment program 1999-2004: Crescent Beach, British Columbia, Canada, LGL Limited Environmental Research Associates, 97 p., http://www. frasersturgeon.com/media/LFRWS-manuscript-2004.pdf.

Paragamian, V.L., 2012, Kootenai River white sturgeonSynthesis of two decades of research: Endangered Species Research, v. 17, no. 2, p. 157-167, http://dx.doi.org/10.3354/esr00407.

Paragamian, V.L., and Wakkinen, V.D., 2011, White sturgeon spawning and discharge augmentation: Fisheries Management and Ecology, v. 18, no. 4, p. 314-321, http://onlinelibrary.wiley.com/doi/10.1111/j.13652400.2011.00785.x/abstract.

Paragamian, V.L., McDonald, R., Nelson, G.J., and Barton, G., 2009, Kootenai River velocities, depth, and white sturgeon spawning site selection-A mystery unraveled?: Journal of Applied Ichthyology, v. 25, no. 6, p. 640-646, http://dx.doi.org/10.1111/j.1439-0426.2009.01364.x.

Parsley, M.J., and Beckman, L.G., 1994, White sturgeon spawning and rearing habitat in the lower Columbia River: North American Journal of Fisheries Management, v. 14, no. 4, p. 812-827, https://doi.org/10.1577/15488675(1994)014\%3C0812:WSSARH\%3E2.3.CO;2.

Parsley, M.J., and Kofoot, Eric, 2013, Effects of incubation substrates on hatch timing and success of white sturgeon (Acipenser transmontanus) embryos: U.S. Geological Survey Scientific Investigations Report 2013-5180, 16 p., https://doi.org/10.3133/sir20135180. 
Parsley, M.J., Beckman, L.G., and McCabe, G.T. Jr., 1993, Spawning and rearing habitat use by white sturgeons in the Columbia River downstream from McNary Dam: Transactions of the American Fisheries Society, v. 122, no. 1, p. 217-227, http://www.genidaqs.net/projects/ columbia_sturgeon/_pdfs/66-Tr_122_p217-27_Spawning _ rearing_hab_use_w-sturgeon.pdf.

Potyondy, John, and Bunte, Kristin, 2002, Sampling with the US SAH-97 hand-held particle size analyzer: Vicksburg, Miss., Federal Interagency Sedimentation Project, 6 p., https://water.usgs.gov/fisp/docs/Instructions_US_SAH97 040412.pdf.

Reed, C.F., Grunsky, C.E., and Crawford, J.J., 1891, Report of the Examining Commission on Rivers and Harbors to the Governor of California [1890], part 14 of California. Examining Commission on Rivers and Harbors, Appendix to the Journals of the Senate and Assembly of the TwentyNinth Session of the Legislature of the State of California, v. 1: Sacramento, Calif., [California] State Printing Office. Parts 1-14 are separately paged, and the paging for part 14 is p. 1-148, accessed March 29, 2017, at https://books. google.com/books?id=sWRBAQAAMAAJ.

Rochard, E., Castelnaud, G., and Lepage, M., 1990, Sturgeons (Pisces: Acipenseridae); Threats and prospects: Journal of Fish Biology, v. 37, Supplement A, p. 123-132, http://dx.doi.org/10.1111/j.1095-8649.1990.tb05028.x.

Schaffter, R.G., 1997, White sturgeon spawning migrations and location of spawning habitat in the Sacramento River, California: California Fish and Game, v. 83, no. 1, p. 1-20, https://www.researchgate.net/publication/289882571_ White_sturgeon_spawning_migrations_and_location_of spawning_habitat_in the_Sacramento_River_California.

Shields, F.D., Jr., 2010, Aquatic habitat bottom classification using ADCP: Journal of Hydraulic Engineering, v. 136, no. 5, p. 336-342, http://dx.doi.org/10.1061/(ASCE) HY.1943-7900.0000181.

Singer, M.B., 2008, Downstream patterns of bed material grain size in a large, lowland alluvial river subject to low sediment supply: Water Resources Research, v. 44, no. 12, p. 1-7, http://doi.org/10.1029/2008WR007183.

Singer, M.B., and Dunne, Thomas, 2004, Modeling decadal bed material sediment flux based on stochastic hydrology: Water Resources Research, v. 40, no. 3, p. 1-14, http://doi.org/10.1029/2003WR002723.

Smith, G.H.S., and Ferguson, R.I., 1995, The gravel-sand transition along river channels: Journal of Sedimentary Research, v. A65, no. 2, p. 423-430, http://dx.doi. org/10.1306/D42680E0-2B26-11D7-8648000102C1865D.
State Water Resources Control Board, 1995, Water quality control plan for the San Francisco Bay/Sacramento-San Joaquin Delta Estuary: Sacramento, Calif., California Environmental Protection Agency, 46 p., http://www. waterboards.ca.gov/waterrights/water_issues/programs/bay_ delta/wq_control_plans/1995wqcp/docs/1995wqcpb.pdf.

Subcommittee on Sedimentation, 1958, A study of methods used in measurement and analysis of sediment loads in streams, Report no. 12, Some fundamentals of particle size analysis: Minneapolis, Minn., Project Offices of Cooperating Agencies at St. Anthony Falls Hydraulic Laboratory, 52 p., http://water.usgs.gov/fisp/docs/Report_12.pdf.

Tinkham, G.H., 1921, History of Stanislaus County California: with biographical sketches of the leading men and women of the county who have been identified with its growth and development from the early days to the present: Los Angeles, Calif, Historic Record Company, 8 p., https://catalog.hathitrust.org/Record/008653314.

United States Army Corps of Engineers, 2013, Report summary for Orestimba Creek, West Stanislaus County, California: U.S. Army Corps of Engineers, Sacramento District, 22 p., http:/www.usace.army.mil/Portals/2/docs/ civilworks/CWRB/orestimba/orestimba_projsum.pdf.

U.S. Geological Survey, 2015a, National Elevation Dataset, accessed March 2016 at http://ned.usgs.gov/.

U.S. Geological Survey, 2015b, National Hydrographic Dataset, accessed March 2016 at http://nhd.usgs.gov/.

Veinott, Geoff, Northcote, Tom, Rosenau, Marvin, and Evans, R.D., 1999, Concentrations of strontium in the pectoral fin rays of white sturgeon (Acipenser transmontanus) by laser ablation sampling-inductively coupled plasma-mass spectrometry as an indicator of marine migrations: Canadian Journal of Fisheries and Aquatic Sciences, v. 56, no. 11, p. 1981-1990, http://dx.doi.org/10.1139/f99-120.

Venditti, J.G., Allison, M.A., Nittrouer, J.A., and Church, M., 2010, Morphology and dynamics of a gravel-sand transition-Proceedings of the 2nd Joint Federal Interagency Conference, Las Vegas: Nevada, June 27July 1, 2010, 11 p., https://acwi.gov/sos/pubs/2ndJFIC/ Contents/9A_Venditti_02_17_10_paper.pdf.

Welch, D.W., Turo, S., and Batten, S. D., 2006, Large-scale marine and freshwater movements of white sturgeon: Transactions of the American Fisheries Society, v. 135, no. 2, p. 386-389, http://dx.doi.org/10.1577/T05-197.1. 
Wright, M.J., 1899, Report of the Surveyor General of the State of California, in Appendix to the Journals of the Senate and Assembly of the Thirty-third Session of the Legislature of the State of California: Sacramento, Calif., 23 p. available at http://clerk.assembly.ca.gov/sites/ clerk.assembly.ca.gov/files/archive/DailyJournal/1899/ Volumes/1899 jnl.pdf.

Zandbergen, P.A., 2009, Accuracy of iPhone locations-A comparison of assisted GPS, WiFi and cellular positioning: Transactions in GIS, v. 13, no. 1, p. 5-25, http://dx.doi.org/10.1111/j.1467-9671.2009.01152.x. 


\section{Appendix 1: River Kilometer Station Locations}

Table 1-1. River kilometer stations, and their associated geographic coordinates, based on the 2012 National Aerial Imagery Program (NAIP) aerial imagery of the lower San Joaquin River.

[River stationing based on channel configuration during 2012 NAIP aerial imagery. North American Datum of 1983. Easting and northing are map grid coordinates based on Universal Transverse Mercater, $10 \mathrm{~N}$, projection. Abbreviations: dd, decimal degrees; Rkm, river kilometer]

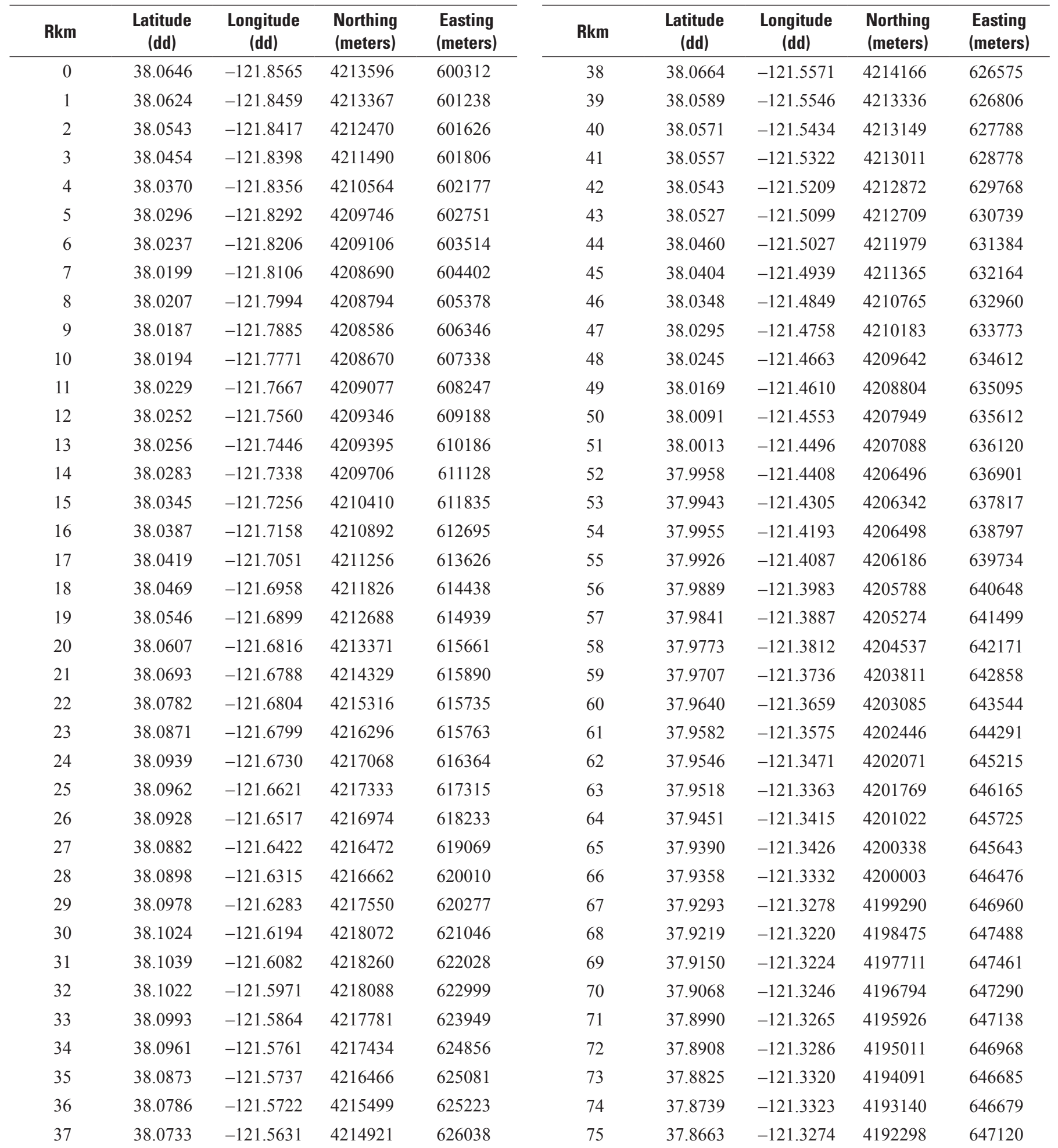


Table 1-1. River kilometer stations, and their associated geographic coordinates, based on the 2012 National Aerial Imagery Program (NAIP) aerial imagery of the lower San Joaquin River.-Continued

[River stationing based on channel configuration during 2012 NAIP aerial imagery. North American Datum of 1983. Easting and northing are map grid coordinates based on Universal Transverse Mercater, 10N, projection. Abbreviations: dd, decimal degrees; Rkm, river kilometer]

\begin{tabular}{|c|c|c|c|c|c|c|c|c|c|}
\hline Rkm & $\begin{array}{l}\text { Latitude } \\
\text { (dd) }\end{array}$ & $\begin{array}{l}\text { Longitude } \\
\text { (dd) }\end{array}$ & $\begin{array}{l}\text { Northing } \\
\text { (meters) }\end{array}$ & $\begin{array}{c}\text { Easting } \\
\text { (meters) }\end{array}$ & Rkm & $\begin{array}{l}\text { Latitude } \\
\text { (dd) }\end{array}$ & $\begin{array}{l}\text { Longitude } \\
\text { (dd) }\end{array}$ & $\begin{array}{l}\text { Northing } \\
\text { (meters) }\end{array}$ & $\begin{array}{c}\text { Easting } \\
\text { (meters) }\end{array}$ \\
\hline 76 & 37.8610 & -121.3204 & 4191717 & 647751 & 117 & 37.6593 & -121.2406 & 4169471 & 655186 \\
\hline 78 & 37.8496 & -121.3236 & 4190448 & 647489 & 119 & 37.6499 & -121.2243 & 4168456 & 656645 \\
\hline 79 & 37.8420 & -121.3202 & 4189616 & 647805 & 120 & 37.6429 & -121.2283 & 4167671 & 656312 \\
\hline 82 & 37.8220 & -121.3181 & 4187393 & 648027 & 123 & 37.6273 & -121.2111 & 4165970 & 657858 \\
\hline 83 & 37.8175 & -121.3149 & 4186905 & 648319 & 124 & 37.6347 & -121.2080 & 4166794 & 658121 \\
\hline 84 & 37.8127 & -121.3175 & 4186362 & 648099 & 125 & 37.6378 & -121.1982 & 4167157 & 658976 \\
\hline 85 & 37.8089 & -121.3273 & 4185929 & 647246 & 126 & 37.6326 & -121.1923 & 4166591 & 659502 \\
\hline 89 & 37.7913 & -121.3073 & 4184006 & 649042 & 130 & 37.6109 & -121.1719 & 4164219 & 661356 \\
\hline 90 & 37.7837 & -121.3038 & 4183170 & 649366 & 131 & 37.6060 & -121.1782 & 4163663 & 660807 \\
\hline 91 & 37.7760 & -121.3022 & 4182316 & 649520 & 132 & 37.5988 & -121.1792 & 4162862 & 660732 \\
\hline 92 & 37.7690 & -121.3035 & 4181536 & 649419 & 133 & 37.5991 & -121.1703 & 4162905 & 661523 \\
\hline 93 & 37.7622 & -121.3090 & 4180774 & 648950 & 134 & 37.5951 & -121.1772 & 4162458 & 660918 \\
\hline 94 & 37.7552 & -121.3047 & 4180003 & 649342 & 135 & 37.5894 & -121.1719 & 4161831 & 661403 \\
\hline 95 & 37.7512 & -121.2977 & 4179573 & 649968 & 136 & 37.5835 & -121.1676 & 4161182 & 661792 \\
\hline 96 & 37.7461 & -121.2911 & 4179022 & 650557 & 137 & 37.5832 & -121.1605 & 4161164 & 662423 \\
\hline 97 & 37.7388 & -121.2973 & 4178196 & 650026 & 138 & 37.5771 & -121.1580 & 4160494 & 662652 \\
\hline 103 & 37.7204 & -121.2720 & 4176195 & 652292 & 144 & 37.5563 & -121.1279 & 4158234 & 665358 \\
\hline 104 & 37.7206 & -121.2611 & 4176235 & 653254 & 145 & 37.5513 & -121.1226 & 4157688 & 665842 \\
\hline 105 & 37.7139 & -121.2673 & 4175487 & 652722 & 146 & 37.5441 & -121.1183 & 4156896 & 666234 \\
\hline 106 & 37.7058 & -121.2720 & 4174582 & 652326 & 147 & 37.5377 & -121.1141 & 4156193 & 666619 \\
\hline 107 & 37.6982 & -121.2730 & 4173733 & 652253 & 148 & 37.5329 & -121.1122 & 4155661 & 666795 \\
\hline 108 & 37.6907 & -121.2732 & 4172905 & 652249 & 149 & 37.5279 & -121.1106 & 4155118 & 666953 \\
\hline 109 & 37.6870 & -121.2698 & 4172502 & 652558 & 150 & 37.5257 & -121.1023 & 4154880 & 667687 \\
\hline 110 & 37.6876 & -121.2592 & 4172580 & 653488 & 151 & 37.5205 & -121.1001 & 4154307 & 667896 \\
\hline 111 & 37.6817 & -121.2610 & 4171924 & 653345 & 152 & 37.5136 & -121.0956 & 4153549 & 668308 \\
\hline 112 & 37.6745 & -121.2646 & 4171118 & 653039 & 153 & 37.5082 & -121.0883 & 4152973 & 668963 \\
\hline 113 & 37.6691 & -121.2557 & 4170532 & 653833 & 154 & 37.5010 & -121.0842 & 4152180 & 669340 \\
\hline 114 & 37.6622 & -121.2492 & 4169776 & 654424 & 155 & 37.4929 & -121.0799 & 4151282 & 669745 \\
\hline 115 & 37.6697 & -121.2460 & 4170614 & 654689 & 156 & 37.4880 & -121.0706 & 4150761 & 670577 \\
\hline 116 & 37.6678 & -121.2431 & 4170407 & 654947 & 157 & 37.4811 & -121.0702 & 4149997 & 670628 \\
\hline
\end{tabular}


Table 1-1. River kilometer stations, and their associated geographic coordinates, based on the 2012 National Aerial Imagery Program (NAIP) aerial imagery of the lower San Joaquin River.-Continued

[River stationing based on channel configuration during 2012 NAIP aerial imagery. North American Datum of 1983. Easting and northing are map grid coordinates based on Universal Transverse Mercater, 10N, projection. Abbreviations: dd, decimal degrees; Rkm, river kilometer]

\begin{tabular}{|c|c|c|c|c|}
\hline Rkm & $\begin{array}{l}\text { Latitude } \\
\text { (dd) }\end{array}$ & $\begin{array}{l}\text { Longitude } \\
\text { (dd) }\end{array}$ & $\begin{array}{l}\text { Northing } \\
\text { (meters) }\end{array}$ & $\begin{array}{l}\text { Easting } \\
\text { (meters) }\end{array}$ \\
\hline 158 & 37.4830 & -121.0639 & 4150214 & 671183 \\
\hline 159 & 37.4784 & -121.0559 & 4149714 & 671900 \\
\hline 160 & 37.4736 & -121.0483 & 4149197 & 672578 \\
\hline 161 & 37.4691 & -121.0434 & 4148710 & 673028 \\
\hline 162 & 37.4645 & -121.0350 & 4148221 & 673780 \\
\hline 163 & 37.4604 & -121.0395 & 4147753 & 673391 \\
\hline 164 & 37.4549 & -121.0402 & 4147147 & 673344 \\
\hline 165 & 37.4496 & -121.0345 & 4146560 & 673856 \\
\hline 166 & 37.4464 & -121.0262 & 4146223 & 674595 \\
\hline 167 & 37.4418 & -121.0232 & 4145715 & 674870 \\
\hline 168 & 37.4340 & -121.0228 & 4144858 & 674924 \\
\hline 169 & 37.4311 & -121.0133 & 4144554 & 675775 \\
\hline 170 & 37.4259 & -121.0095 & 4143982 & 676127 \\
\hline 171 & 37.4285 & -121.0004 & 4144281 & 676921 \\
\hline 172 & 37.4209 & -121.0022 & 4143435 & 676778 \\
\hline 173 & 37.4150 & -121.0023 & 4142788 & 676783 \\
\hline 174 & 37.4113 & -120.9963 & 4142389 & 677323 \\
\hline 175 & 37.4057 & -120.9967 & 4141759 & 677302 \\
\hline 176 & 37.4032 & -120.9903 & 4141493 & 677874 \\
\hline 177 & 37.3984 & -120.9841 & 4140980 & 678437 \\
\hline 178 & 37.3924 & -120.9913 & 4140299 & 677813 \\
\hline 179 & 37.3865 & -120.9944 & 4139639 & 677556 \\
\hline 180 & 37.3868 & -120.9864 & 4139684 & 678262 \\
\hline 181 & 37.3810 & -120.9843 & 4139044 & 678457 \\
\hline 182 & 37.3760 & -120.9816 & 4138495 & 678711 \\
\hline 183 & 37.3757 & -120.9737 & 4138479 & 679410 \\
\hline 184 & 37.3701 & -120.9779 & 4137844 & 679051 \\
\hline 185 & 37.3674 & -120.9767 & 4137553 & 679169 \\
\hline 186 & 37.3628 & -120.9788 & 4137035 & 678990 \\
\hline 187 & 37.3542 & -120.9770 & 4136087 & 679173 \\
\hline
\end{tabular}



Publishing support provided by the U.S. Geological Survey Science Publishing Network, Sacramento Publishing Service Center

For more information concerning the research in this report, contact the Director, California Water Science Center U.S. Geological Survey $6000 \mathrm{~J}$ Street, Placer Hall Sacramento, California 95819 http://ca.water.usgs.gov 
